\title{
UM SISTEMA DE INFORMAÇÕES PARA USUÁRIOS DE TRANSPORTE COLETIVO EM CIDADES DE MÉDIO PORTE
}

HENRIQUE DO NASCIMENTO MARQUES

Dissertação apresentada à Escola de Engenharia de São Carlos da Universidade de São Paulo, como parte dos requisitos para obtenção do titulo de Mestre em Engenharia: Área de Concentração Transportes.

ORIENTADOR: Prof. Dr. Antônio Nélson Rodrigues da Silva

São Carlos

1998 


\section{AGRADECIMENTOS}

A Deus, por tudo.

Ao meu pai José, a minha mầe Valdenize, as minhas irmầs, Cristine, Màrcia c Denize e a toda a minha familia pelo apoio e encorajamento sempre presentes em todos as etapas para a realização deste trabalho.

Ao professor Antônio Nélson Rodrigues da Silva pela competente orientação, amizade e contribuição para 0 amadurecimento protissional.

A minha tia Yêda por todas as oraçồes a mim dedicadas.

A Ana Paula pelo apoio, dedicaçâo, carinho e compreensào, sem os quais nåo teria encontrado inspiraçăo suficiente.

Ao Engenheiro Mauricio Olbrick Rodrigues pela concessão dos dados utilizados neste trabalho, sem os quais não teria sido possivel a sua realização.

Aos professores do Departamento de Transportes da Universidade Federal do Ceará pelo apoio e incentivo.

Ao Departamento de Transportes da EESC-USP pela estrutura e equipamentos.

Aos professores e limeionários da pós-graduação pela excelente convivểncia.

Aos novos amigos, pela amizade e alegria compartilhadas nestes dois anos de estudo.

A Coordenadoria de Aperfeiçoamento de Pessoal de Nivel Superior - CAPES, pelo suporte financeiro.

Enfim, a todas as pessoss que de uma forma ou de outra contribuiram para a realização deste trahalho. 


\section{SUMÁRIO}

LISTA DE FIGURAS

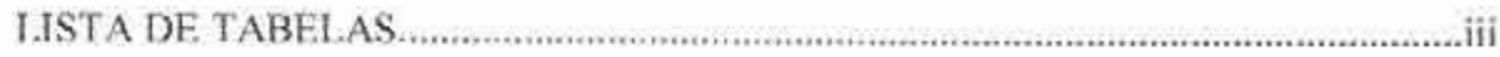

RESUMO

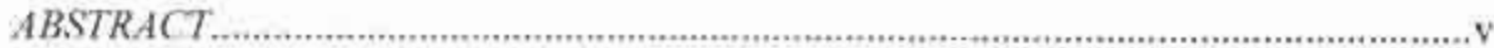

1. INTRODUÇÃO

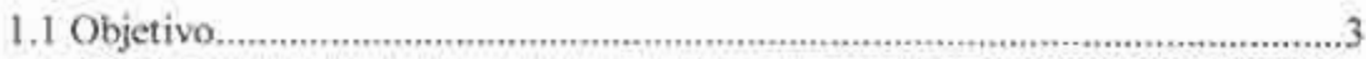

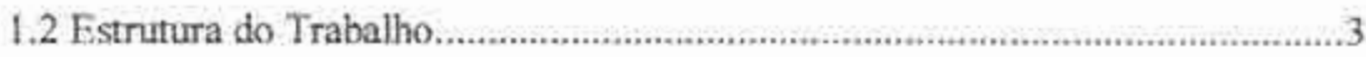

2. TRANSPORTE PÚBLICO URBANO

2.1 Introdução.

2.2 Modos de Transporte Urbano.........................................................................

2.2.1 A Importância do Transporte Público Urbano...................................8

2.2.2 Caracteristicas Gerais dos Modos de Transporte Público.................9

2.3 Qualidade no Transporte Público Urbano......................................................11

2.4 Transporte Coletivo Urhano por Ônibus.......................................................14

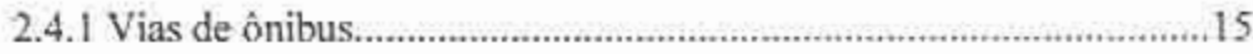

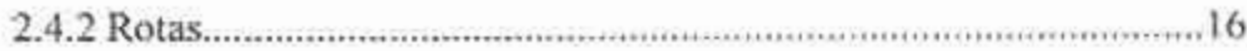


2.5 Sistema de Informaçôes aos Usuários...........................................................22

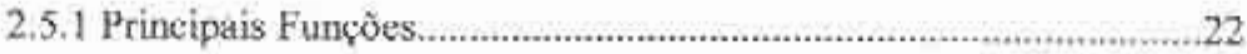

2.5.2 Comunicação com o Público ...........................................................22

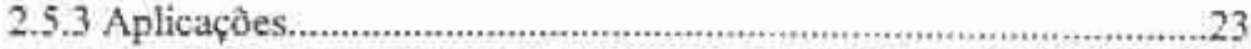

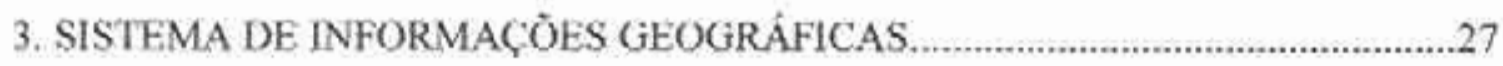

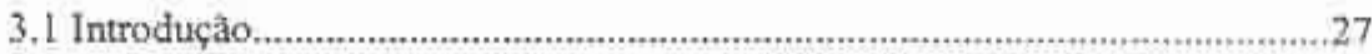

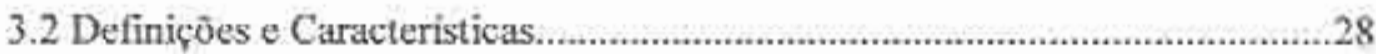

3.3 Componentes de um SIG

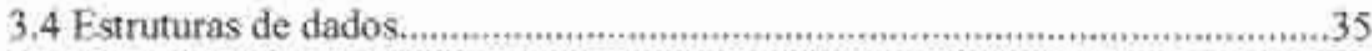

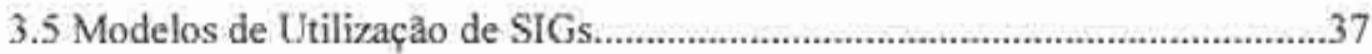

3.6 Os Sistemas de Informaçôes Geográficas e a Engenharia de Transportes no

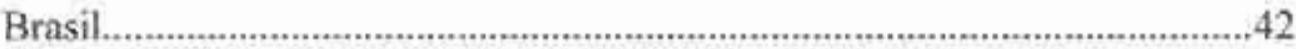

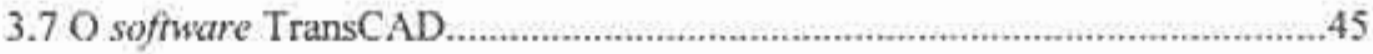

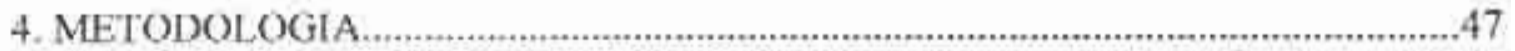

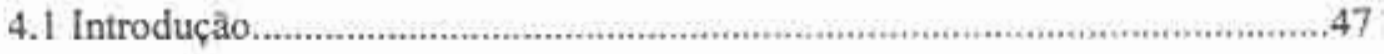

4.2 Funcionamento do Atendimento a Consultas................................................48 
4.3 Itapas da Metodologia Empregada.

4.3.1 Aprendizado do Sofiware.

4.3 .2 Coleta de Dados,..............................................................................53

4.3.3 Hardware Usado,..................................................................55

4.3.4 Entrada de Dados...............................................................................5.

4.3.5 Processamento de Dados.................................................................58

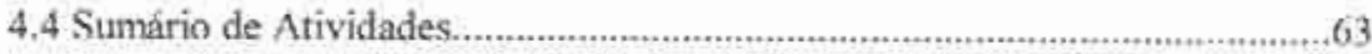

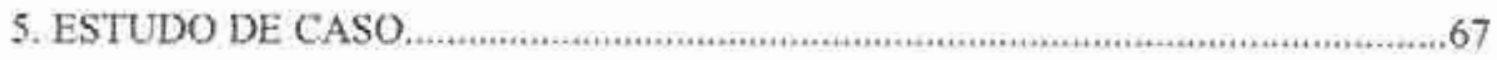

5,1 Introduçẳo

5.2 Area do Estudo de Caso................................................................................68

5.2.1 Critérios de Definiçăo ................................................................68

5.2.2 Dados Utilizados...................................................................70

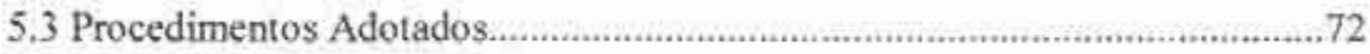

5.4 Aplicação do Sistema de Consulta de Itinerários............................................76

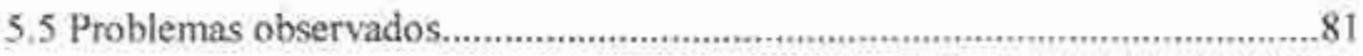

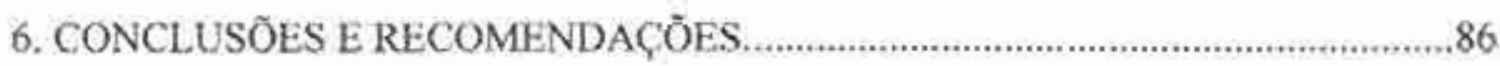

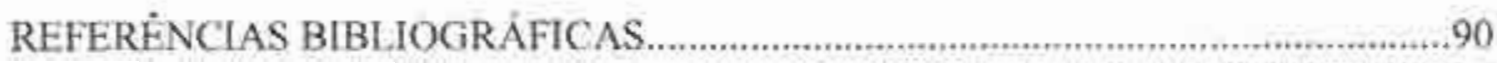




\section{LISTA DE FIGURAS}

FIGURA 3.1 - Elementos de um Sistema de informaçỏes Geográficas 29

FIGURA 3.2 - Mapa temático gerado por um SIG. 30

FIGURA 3,3 - Estrutura raster e wector 36

FIGURA 4.I - Fluxograma de processamento de consultas. 48

FIGURA 4.2 - Descriçâo dos capitulos do tutorial para o sofftware TransCAD 3,0,....,.,53

FIGURA 4.3 - Imagem vetorial do sistema viario digitalizado. 56

FIGURA 4.4 - Detalhe de um mapa de localização dos pontos de ônibus da cidade de Sào Carlos-SP

FIGURA 4,5 - Representação gráfica da localizaçăo da origem e do destino informados pelo passageiro 59

FIGURA 4.6-Resposta gerada pelo programa sobre a localização geográfica de endereços 60

FIGURA 4.7 - Representação gràfica de uma rota de ônibus. 61

FIGURA 4.8 - Rotas agrupadas utilizando o recurso fracking. 62

FIGURA 4.9-Informações adicionais sobre as linhas de ônibus. 65

FIGURA 51 - Localização da área de estudo 69

FIGURA 5.2 - Sistema de transporte coletivo de São Carlos. 70

FIGURA 5.3 - Parte da base de dados de ruas contendo os nomes dos logradouros. 71 
FIGURA 5.4 - Modelo utilizado pelo sofrware para a localização geográfica do passageiro

FIGURA 5.5 - Tela comendo a origem e o destino fornecidos pelo passageiro. .77

FIGIJRA 5.6 - Tela com resultados do caminho mínimo. 78

FIGURA 5.7 - Saida dos resultados gerados pelo software sobre a consulta de itinerários. .79

FIGURA 5.8 - Rota ótima representada entre origem e destino fornecido pelo usuário. 


\section{LISTA DE TABELAS}

TABELA 2.1 - Principais caracteristicas técnicus dos modos de transponte público.......1

TABEL.A 2.2 - Instalaçòes necessarias ao ponto de parada.........................................21

TABELA 3.1 - Modelos de utilizaçâo de SIGs e seus beneficios imediatos ....................41

TABEL A 4.1 - Mapas digitalizados requeridos neste projeto ..........................................57

TABELA 5.1 - Cronograma da principais etapas do projeto............................................85 


\section{RESUMO}

MARQUES. H.N. (1998). Um sistema de informações para usuários de transporte colerivo em cidades de médio porte. São Carlos - SP. 1998. 96p. Dissertaçâo (Mestrado) - Escola de Engenharia de Sato Carlos, Universidade de Săo Paulo.

O presente trahalho propồ a implantação de um sistema de consulta por telefone para usuátrios de transporte coletivo, baseado num Sistema de Informaçðes Geográficas (SIG), oferecendo dentre outras informaçñes referentes ao sistema de transporte pủblico. as rotas otimas entre origens e destinos informados pelos passageiros. Este sistema se fundamenta em uma base de dados ampla e atualizada, com uma grande gama de informaç̄̄es sobre a rede de transpporte público, incluindo: cadastro de logradouros, malha de eirculação viária, pontos de parada e itinerários de linhas de ómibus. Escolheuse como estudo de caso o sistema de transporte coletivo da cidade de Sån Carlos - SP. cujas principais informaçōes foram obtidas na forma cartografica $\mathrm{c}$ transferidas para o formato digital, via mesa digitalizadora e através de rotinas especificas do sofiware. Os dados espaciais e atributos, necessários a aplicaçâo do sistema proposto, foram processados em um sofiware para SIG, denominado TransCAD, que constitui uma poderosa ferramenta de planejamento, gerência, operação e análise de sistemas de transporte. Os resultados aqui obtidos indicam que pode ser viável implantar um sistema de consulta dessa natureza em eidades de porte médio, sem grandes investimentos, desde que haja mảo-de-obra qualificada e um treinamento prévio dos técnicos que irào operálo, como condiçòes essenciais para o sucesso do projeto. 


\begin{abstract}
MARQUES. H.N. (1998) A transit information system for medium-sized cities Săo Carlos - SP, 1998. 96p. Dissertaçẫo (Mestrado) - Escola de Engenharia de São Carlos, Universidade de Săo Paulo.

The purpose of this study is to propose the implementation of a transit information system based on a Geographic Information System (GIS). The new system is designed to offer information by telephone about the public transportation system, such as the optimal routes between the origins and destinations provided by the system's users. This query system is based on a broad and updared datahase, that comains a large amount of information on the city's transit network, including the names of all the city's street, the network of streets accessible by bus. bus stops and routes. The public transportation system of the city of Sas Carlos, located in the state of Sao Paulo, was selected for a case study. Both spatial and nonspatial data needed for application of the proposed system were processed in the same GIS software, called TransC.AD, which is a powerfil tool for planning, management, operation, and analysis of transportation systems. The basic geographic information has been transferred from printed maps - the main sources of this type of data - to digital format with the help of software routines and a small digitizing tablet. The results obtained in this study suggest that the system can be implemented easily in medium-sized Brazilian cities, without the need for significant investments. The basic requirements for the success of this kind of project are as follows: a qualified staft to implement the system, and some prior training for the technician who is going to operate the system.
\end{abstract}




\section{INTRODUÇÃO}

O sistema de transporte é hoje tăo importante quanto as demais redes de infraestrutura (água, esgoto, gás, pavimentação, iluminação, telefonia, etc.) de qualquer regiảo e o grau de desenvolvimento e crescimento de uma cidade está ligado dirctamente ao grau de sofisticação do scu sistema de transporte. Toda cidade requer mobilidade para o seu funcionamento - pessoas precisam se locomover de suas residências para os locais de trahalho, insumos e bens acabados precisam chegar até os consumidores, etc. De uma maneira geral, as opçoes de trabalho, lazer e compras e o acesso á saúde, educação, cultura e informaçőes dependem da qualidade do sistema de transporte.

Num pais onde mais de 78 milhòes de viagens motorizadas são realizadas por dia: estima-se que mais de $70 \%$ sejam realizadas por meios dos transportes coletivos. Aproximadamentc $62 \%$ das pessoas que utilizam os coletivos têm por motivo o trabalho. Isto comprova sua importância social e seu papel como instrumento de produção (PADILHA, 1998).

Os usuários cativos do sistema de transporte público conheeem bem as linhas que utilizam para os seus deslocamentos diários, porém algumas vezes precisam utilizar linhas, as quais não estão habituados. Agora imagine que um usuário não cativo (um turista, por exemplo) decida conhecer os principais pontos turísticos da cidade de onibus. Antes de se locomover de um lugar para outro, ele precisa saber a melhor maneira de chegar ao seu destino. Então surgirão as primeiras indagaçōes: Decidir para onde ir? Como chegar lá? Qual o melhor caminho? Ou seja, como obter mais 
informaçôes sobre o sistema de transportes. Encontrar respostas a estas perguntas, è justamente isso que um sistema de informaçào se propốe a fazer pelo usuário.

Um sistema de informações está voltado á qualificação do serviço de transporte público, onde os usuários possam dispor de um sistema de transporte mais eficiente e eficaz, contribuindo assim para a melhoria da prestação dos serviços essenciais á sociedade. Desta forma, quando o nivel de utilizagão dos automóveis for tão elevado que já não permita uma circulaçào livre de congestionamentos (o que já se observa nas grandes cidades), pode-se até esperar que ocorra uma maior atraçåo dos usuários de veiculos particulares para o modo ônibus, reduzindo o numero de automóveis nas vias. oferecendo um fluxo menos congestionado e propiciando uma melhoria na qualidade ambiental com a redução de poluentes.

A motivaçāo para realizar este trabalho surgiu pela dificuldade que enfrentam os passageiros do sistema de transporte coletivo em conseguir informaçð̄es sobre os itinerários que os ônibus percorrem, os horảrios disponiveis, a freqüência oferecida pelo serviço, dentre outras. A idéia é de fornecer subsidios para a criaça de centrais de atendimento aos usuários (CAU), com a finalidade de receber reclamaçôes e prestar informaçōes sobre o sistema de transporte püblico, utilizando-se o Sistema de Informaçōes Geográficas (SIG), que é uma tecnologia em contimuo processo de expansão na soluçầo de problemas de transpontes. O Sistema de Informaçōes Gcográficas vem ao encontro desta realidade, devido ao scu potencial de integração com o usuário, de sua capacidade de cruzamento de informaçōes geográficas, velocidade de operação, capacidade de simulaçóes e versatilidade na apresentação de informaçôes espaciais.

A idéin de elaborar um sisterna de informações para usuários de transporte público baseado $\mathrm{cm}$ SIG nảo ê nova. Significativos esforços foram observados nos trabalhos de ZUPPO et al. (1996). NASSI et al. (1996) e DAVIS (1997). Em todos estes trabalhos foram observadas dificuldades em desenvolver algoritmos e programas 
externos ao Sistema de Informaçōes Geográficas para solucionar problemas de caminho mínimo.

O sistema de consulta proposto neste trabalho, que deverá agilizar o fornecimento de informaçøes aos usuários do sistema de transporte coletivo, por meio do atendimento telefônico, contará $\mathrm{com}$ recursos de análise de rede contidos em um sofiware de SIG para transportes, denominado TransC.AD, sem a necessidade de recorrer a algoritmos ou programas externos ao sofiwure. Desta forma, podera proceder à localização geográfica de endereços e pontos de referència, sendo capaz de determinar as rotas ótimas, via ònibus. entre dois pontos quaisquer.

\subsection{Objetivo}

Este trabalho pretende fornecer subsidios para a implantação de um sistema de informaçōes para usuários de transporte coletivo (sistema de consulta por telefone). apoiado em um SIG, oferecendo informaçōes relativas a tarifas, linhas, itinerários, localizaçâo dos pontos de parada, horários. frequêneia e deterninaçáo de rotas otimas entre origens e destinos informados pelos passageiros.

\subsection{Estrutura do Trabalho}

Esta dissertação está estruturada em 6 capitulos. O capitulo 2, Transporte Público Urhano, apresenta as principais caracteristicas dos modos de transporte público urbano; destaca como a qualidade no transporte público urbano é importante; justifica a predominància de uso do ônibus com relação as outras modalidades c, finalmente, mostra como a comunicação com o público influi na melhoria dos serviços prestados a populaçà̃o. 
O capitulo 3, Sistema de Informações Geográficas, apresenta características e conceitos gerais de SIG e traça um breve panorama da utilização do SIG no planejamento urbano. $O$ capitulo 3 também contém uma rápida revisào dos trabalhos publicados nos principais congressos, simpósios, seminários e revistas que abordarn a questão dos transportes no Brasil e, por último, introduz o software de SIG que será utilizado neste trabalho.

O capitulo 4. Metodologia. faz uma descrição detalhada do método cmpregado neste trabalho e apresenta o funcionamento do sistema de consulta de itinerários.

Para destacar os aspectos importantes deste sistema, um estudo de caso, baseado nas linhas de ônibus que compõem o sistema de transporte coletivo da cidade de São Carlos - SP. é apresentado no capitulo 5, Estudo de Caso. Os principais aspectos do sistema de consulta apresentado no capitulo antcrior, bem como o procedimento para a utilização do mesmo são discutidos com a ajuda do estudo de caso.

Finalmente, o capitulo 6. Conchtusôes e Recomendaçōes, apresenta as conclusões extraídas do trabalho e menciona recomendaçōes e sugestões para futuros trabalhos. 


\section{TRANSPORTE PÚBLICO URBANO}

Neste capitulo, apresenta-se uma classificação e um retato sucinto das caracteristicas dos modos de transporte publico urbano: relata-se a importancia da qualidade no transporte público: introduz-se o rransporte coletivo por ônihus, justificando a sua predominância em relação as outras modalidades e descrevendo us formas de tratamento com relaçảo as vias, rotas pontos de parada e. finalmente. mostra-se como a comunicação com o público influi na melhoria dos serviços prestados à populaçâo.

\subsection{Introdução}

Transporte é a denominação dada à movimentação de pessoas e de produtos. $\mathrm{O}$ ideal é que esta movimentação se dê de modo seguro, rápido, confortável, conveniente, e econômico, com o minimo de interferência com o meio ambiente.

A constante necessidade de deslocamentos nas cidades modernas faz com que a qualidade do sistema de transporte urbano seja tão importante para a qualidade de vida da população quanto os serviços essenciais, tais como: coleta de esgoto, abastecimento de àgua, fornecimento de energia elétrica, etc.

Segundo FERRAL (1997), aproximadamente $80 \%$ da população vive nas cidades. O Brasil tem 120 milhōes de pessoas vivendo $\mathrm{em}$ aglomerados urhanos, cerca 
de $75 \%$ da população total de 160 milhōes. Fstima-se que daqui a 50 anos, quando a população brasileira se estabilizar en cerca de 240 milhòes de habitantes, a populaçăo urbana no pais deverá alcançar 192 milhǒes, considerando um aumento no indice de urbanização de $75 \%$ para $80 \%$. Esses valores evidenciam a relevância do equacionamento adequado da questào do transporte ubsano no pais, pois a qualidade desse transporte afetará a qualidade de vida da grande maioria da população.

As cidades brasileiras apresentam problemas sérios de transporte e qualidade de vida, tais como: queda da mobilidade e da acessibilidade, aumento dos congestionamentos, aumento nos impactos ambientais produzidos pelos sistemas de transportes (sobretudo poluiçâo sonora e atmosférica), altos indices de acidentes de trânsito, maiores tempos de viagem e conseqüentemente redução na qualidade de vida para moradores destas áreas (BALASSIANO, 1997). Esta situaçăo decorte de muitos fatores sociais, politicos $c$ econòmicos, mas resulta também de decisōes passadas relativas às politicas urbanas, de transporte e trânsito.

Com o pais atravessando um periodo de relativa estabilidade econômica, apresentando baixas taxas de inflação, o crédito ao consumidor foi facilitado e com isso uma parcela significativa da população tem hoje acesso mais facil ao automóvel, cuja frota cresceu acentuadamente. Formou-se, assim, uma cultura do automóvel, responsável pelo desvio de muitos recursos para atender as suas necessidades. Simultaneamente, os sistemas de transporte público, apesar de terem sido contemplados com alguns investimentos importantes, não estão sendo suficientes para atender a uma demanda que não pára de crescer. Eles têm passado por crises cíclicas provocadas principalmente pela incompatibilidade entre custos, tarifas e receitas, pelas deficiências na gestão e operaçào e pelas dificuldades de se conseguir prioridade efetiva de circulaçâo (ANTP, 1997a).

Os sistemas de transporte público passam por um declinio na sua importância, na sua eficiência e na sua confiabilidade junto ao público, tornando-se um mal necessário para aqueles que nâo tềm outra opçào de deslocamento. Como conseqüência imediata. houve a formaçà̃o de dois grupos que refletem, na prática, as desigualdades sociais e: 
econỏmicas de nossa sociedade: os que têm acesso ao automóvei e os que precisam do transporte público, ou seja. enquanto uma parcela reduzida goza das melhores condiçōes de transporte, a maioria contimua tendo o seu direito de ir e vir limitado (ANTP. 1997a).

A necessidade de uma grande mobilizaçăo toma-se cada vez mais evidente. Hoje mais de $75 \%$ da populagào brasileira vivem em áreas urbanas, nas quais a maioria das pessoas precisa do transporte coletivo para os seus deslocamento diärios. As condições atunis de transporte såo precárias para a maioria da populaçăo, pelo desconforto, congestionamentos e acidentes. Com o objetivo de reverter esta situação, é necessário fazer um reexame do modelo atual de transporte e circulação das cidades brasileiras, que proporcione melhores opçôes de deslocamento, juntamente com uma maior eficiência geral do sistema. Isto só pode ser obtido caso o processo de desenvolvimento urbano e as politicas de transporte $\mathrm{c}$ trànsito sejam revistas, de forma a gerar um equilibrio entre os vários modos, que aumente a eficiência geral do sistema e garanta condiçôes adequadas para a maioria dos usuários (ANTP, 1997a). Para se conseguir estes resultados, as políticas necessárias devem ser adotadas, de acordo com a ANTP' (1997a). de forma a garantir:

- Melhor qualidade de vida para toda a população, traduzida por condições dignas de transporte, segurança de trânsito e acessibilidade para a realização das atividades essenciais à vida moderna:

- Eficiência. demonstrada pela disponibilidade de uma rede de transportes integrada por modos complementares, trabalhando em regime de eficiência, com prioridade efetiva para os meios coletivos;

- Qualidade ambiental, representada pelo controle dos níveis de poluiçâo atmosférica e sonora, pela proteçào do patrimônio histórico, arquitetônico. cultural e ambiental e das áreas residenciais e de vivência coletiva contra 0 trânsito indevido de veiculos. 


\subsection{Modos de Transporte Urbano}

Uma das classificaçóes mais difundidas sobre os modos de transporte urbano de passageiros é proposta por VUCHIC (1981). Segundo esta classificação, os modos sào divididos em três grandes grupos: privado, público e semi-público ou de aluguel.

No modo privado, o usuário é o proprietário do veiculo, possuindo total flexibilidade no tempo e no espaço. Modos mais comuns de transporte privado: o modo à pé, sendo o veiculo o próprio corpo humano, bicicleta, motocicleta, automóvel e veículo com tração animal.

No modo público. os veiculos percorrem rotas e horários pré-definidos. Os veículos possuem maior capacidade, mas não possuem flexibilidade espacial nem temporal. $\mathrm{O}$ usuário pode utilizar livremente os veiculos em circulação, desde que pague a tarifa estabelecida pela empresa operadora. Modos mais comuns de transporte público: ônibus, trólebus, bonde, pré metrô, metrô e trem de subưbio.

No modo semi-público, o usuário encontra caracteristicas intermediárias entre o público e o privado. Modos mais comuns de transporte semi-público: táxi, carona programada (carpoot), lotação, veículos fretados ou de aluguel.

\subsubsection{A Importância do Transporte Público Urbano}

Apesar do automóvel ser na atualidade um dos principais modos de transporte urbano e oferecer uma série de vantagens com relaçào aos demais modos, ele não será o alvo desse estudo. Os modos de transporte semi-público também não serão aqui analisados, por não representarem uma parcela significativa no Brasil. Dentre os vários modos de transporte urbano, o transporte público, representado pelo modo ônibus. se constitui no modo mais importante no Brasil, pois é o responsável por mais da metade das viagens urbanas realizadas. 
Segundo FERRAZ (1997), o transporte público constitui um serviço indispensável nas cidades, apresentando um papel social e econômico de extrema importância, pois:

- Democratiza a mobilidade, permitindo a locomoçăo para aqueles que nâo possuem automóvel ou não podem dirigir (pobres, idosos, crianças, adolescentes, deficientes fisicos, etc.);

- Constitui uma ahernativa de transporte em substituição ao automóvel, aliviando os congestionamentos, a poluição c o uso abusivo de energia automotiva (principalmente do petróleo, uma vez que as fontes são finitas c nâo renovávecis);

- Ainda como substituto do automóvel, reduz a necessidade de investimentos na construçäo de vias e estacionamentos, etc., permitindo que os recursos sejam destinados a setores de maior relevância social, bem como uma utilizaçåo mais racional e humana do solo urbano.

\subsubsection{Características Gerais dos Modos de Transporte Público}

De maneira genérica, os principais tipos de tecnologia empregados no transporte público urbano săo: ônibus, ônibus elétrico ou trólebus, bonde. prè-metró, metrô e trem de subúrbio. A seguir será feita uma descrição sucinta das tecnologias, baseados em estudos realizados por FERRAZ (1997).

$\mathrm{Na}$ grande maioria das vezes. os ônibus e trólebus se movimentam junto com o tráfego em geral. A locomoção em faixas parcialmente ou totalmente segregadas tem sido adotado nos corredores congestionados das grandes cidades. com o objetivo de aumentar a velocidade comercial e a capacidade do modo. Os onibus comuns apresentam largura máxima em torno de $2,6 \mathrm{~m}$ e comprimento limite por volta de $12 \mathrm{~m}$. os ônibus com $10 \mathrm{~m}$ de comprimento têm capacidade para cerca de 80 passageiros. $\mathrm{A}$ capacidade dos onibus de $12 \mathrm{~m}$ chega a 105 passageiros. Veículos articulados, com $18 \mathrm{~m}$ 
de comprimento, têm capacidade para até 180 passageiros e bi-articulados, com $24 \mathrm{~m}$, capacidade para 240 pessoas.

A modalidade honde alimentada com energia eletrica foi o primeiro sistema de transporte público motorizado. Atuaimente vefoulos modernos com comprimentos entre 14 e $23 \mathrm{~m}$ operando sozinhos ou em comboios de 2 ou 3 unidades, são empregados em algumas cidades do mundo; a maior parte se movimenta junto com o tráfego normai (movimentos em faixas exclusivas são exceçōes). A capacidade dos bondes comuns situa-se entre 130 e 230 passageiros, dependendo do tamanho e do layout interno.

O sistema conhecido por pré-metrô é qunse sempre implantado em faixas totalmente segregadas. Raros sâo os casos de movimento junto com o tráfego em geral. Os veiculos tẻm comprimentos entre $14 \mathrm{~m}$ e $30 \mathrm{~m}$, com capacidade entre 150 e 350 passageiros, dependendo do tamanho e do layout interno.

O metró opera $\mathrm{em}$ vias específicas completamente isoladas, possibilitando grandes velocidades e capacidades. Os vé́culos típicos empregados no transporte metroviário têm largura entre 2.5 e $3.2 \mathrm{~m}$ e comprimento entre 15 e $23 \mathrm{~m}$, com capacidade entre 160 a 300 passageiros, dependendo do tamanho e do layout interno. O transporte é normalmente realizado em combojos de 4 a 10 unidades agrupadas.

O sistema denominado trem de subúrbio refere-se ao transporte de caracteristicas regionais/locais realizado nas grandes metrópoles, nas mesmas vias do transporte ferroviário interurbano já existentes. $O$ sistema é caracterizado por viagens relativamente longas, grande distância entre testações e alta velocidade. Os veiculos empregados são em geral os mesmos do transporte de passageiros interurbano, largura ontre 2,5 e $3,2 \mathrm{~m}$ e comprimento de 20 a $26 \mathrm{~m}$, com capacidade entre 180 e 250 passageiros. $O$ transporte é normalmente realizado em comboios de 4 a 10 carros. 
A tabela 2.1 apresenta, em intervalos de valores, um resumo das caracteristicas técnicas mais importantes dos principais modos de transporte público urbano.

TABELA 2.1 - Principais caracteristicas técnicas dos modos de transporte público.

\begin{tabular}{|l|c|c|c|c|c|}
\hline \multirow{2}{*}{ Caracteristicas } & \multicolumn{5}{|c|}{ Modos } \\
\cline { 2 - 6 } & Ónibus & Bonde & VLT & Metró & Subúrbio \\
\hline Largura (m) & $2,4-2,6$ & $2,4-2,6$ & $2,4-2,8$ & $2,5-3,2$ & $2,5-3,2$ \\
\hline Comprimento (m) & $10-24$ & $14-23$ & $14-30$ & $15-23$ & $20-26$ \\
\hline Capacidade (pass) & $80-240$ & $130-230$ & $150-350$ & $160-300$ & $180-250$ \\
\hline Unidades em comboio & $1-4$ & $1-3$ & $1-4$ & $4-10$ & $4-10$ \\
independ. & engatadas & engatadas & engatadas & engatadas \\
\hline Velocidade (km/h) & $10-20$ & $10-20$ & $20-40$ & $25-60$ & $40-70$ \\
\hline Capacidade (mil pass/h) & $5-15$ & $5-15$ & $10-30$ & $25-60$ & $20-50$ \\
\hline $\begin{array}{l}\text { Distância } \\
\text { entre paradas (m) }\end{array}$ & $200-400$ & $200-400$ & $400-800$ & $700-2000$ & $1500-4000$ \\
\hline
\end{tabular}

Fonte: FERRAZ (1997).

\subsection{Qualidade no Transporte Público Urbano}

A qualidade de vida urbana tem sido motivo de preocupação para diversos segmentos da sociedade e para a populaçào em geral. Dentro deste contexto, os serviços de transporte público desempenham papel importante no espaço urbano, determinando. principalmente para aqueles com menor poder aquisitivo, o direito de ir e vir em busca do trabalho, da cultura e do lazer (BAI.ASSIANO. 1997).

Nas cidades brasileiras, os sistemas de transportes operam muitas vezes com baixa produtividade, pouca confiabilidade. freqüência irregular, inadequação tecnológica, entre outros problemas que poderiam ser listados (BALASSIANO, 1997). A falta de qualidade desses sistemas e o rápido aumento da frota de veiculos, justificam parcela significativa dos problemas de circulação enfrentados $\mathrm{em}$ muitas cidades 
brasileiras. Para se ter uma idéia do tamanho da frota de veiculos no pais: havia 1,4 mithão de veículos em 1966, 23.5 milhỏes em 1996, e um estudo elaborado pelo GEIPOT (Empresa Brasileira de Planejamento de Transporte) projeta a duplicaçâo da atual frota nos próximos dex anos (PADIL.HA. 1998).

A expansão da frota de ônibus clandestinos operando nas principais capitais brasileiras pode ser em parte atribuida ao baixo nivel de serviço oferecido pelas cmpresas operadoras. Atualmente veículos de baixa capacidade (vans e kombis) passaram a tazer concorrëncia aos ónibus na operąalo dos principais corredores, numa operação, na maior parte dos casos. desregulamentada (BAI.ASSIANO. 1997).

Diante das novas exigências da sociedade, empresas de diversos ramos têm cada vez mais abordado a qualidade como um fator de competitividade e de sobrevivência. Neste comtexto, o setor de transportes não poderia ficar excluido de tal movimento, porém quando comparado com os exemplos nacionais de transporte rodoviário de carga e de transporte aćreo, observa-se que o transporte coletivo por ônibus. de uma maneira geral, deixa muito a desejar.

Uma das principais preocupações de quem planeja um Sistema de Transporte Coletivo é a busca por um equilibrio entre a manutenção de uma tarifa reduzida (que seja acessivel à população) e a melhoria na qualidade dos serviços ofertados aos usuários (de segurança, conforto, eficiência e confiabilidade) (BARTOLI et aL., 1996).

Dois aspectos do transporte coletivo urbano são essenciais: a eficácia e a eficiência. A eficácia refere-se à qualidade do serviço e a eficiência ả produtividade do mesmo. No planejamento de sistemas de transporte público das cidades. o objetivo principal é oferecer um serviço de qualidade satisfatória (eficácia em nivel aceitảvel), ao menor custo possivel (eficiência máxima) (SILVA \& FERRAZ, 1991).

De acordo com a MERCEDES BENZ DO BRASLL (1987), as exigências do passageiro. consideradas relevantes para a qualidade do serviço de transporte coletivo por ônibus, são: 
- Distâncias curtas a pé aos pontos de parada mais próximos por onde passam os ònibus que văo ao destino desejado ou ả sua vizinhança;

- Segurança (reduça dos riscos de acidentes entre veículos, conflitos e assaltos no interior dos veículos);

- Minimo tempo de espera:

- Confiabilidade (cumprimento do horário preestabelecido, poucas quebras);

- Viagens rápidas (fluidez no tráfego e nos pontos de parada);

- Conforto (auséncia de baldeaçōes ou entåo integrações coordenadas e rápidas; número de passageiros por metro quadrado; limpeza dos ônibus. terminais, paradas, etc.):

- Tarifas baixas; e

- Atendimento dos seus desejos de deslocamentos (60\% trabalho, $23 \%$ estudo).

Deve-se observar que, na pràtica, dificilmente o passageiro tem estas exigências cumpridas satisfatoriamente. As distâncias para os pontos de parada, às vezes ș̀ inadequadas, tendo a passageiro que percorrer longas distâncias a pé para pegar o ônibus. Os tempo de espera sào longos e a viagem demorada. tendo o passageiro que usar vários meios de transportes sem integração modal c tarifária, sendo obrigado a pagar mais de uma tarifa,

Embora estas exigèncias tenham definiçôes próprias e objetivas, elas representam valores subjetivos que passam pela percepçào đo passageiro, que é influenciado por um conjunto de características próprias do indivíduo. Desta forma. torna-se essencial considerar o perfil do passageiro, podendo-se então analisar as diferentes maneiras de percepçâo, peculiares de cada grupo, ou seja, como os passageiros enxergam o transporte e o que desejam deste serviço. 


\subsection{Transporte Coletivo Urbano por Ônibus}

$O$ transporte coletivo urbano existe em funçào das atividades e necessidades econômicas e sociais dos habitantes de uma commidade, sendo indispensável em comunidades carentes de recursos, una vez que o automóvel particular não está ao alcance de todos. Já em comunidades abastadas, a falta de condições espaciais para os deslocamentos essenciais provocados por congestionamentos e estacionamentos desestimulam o uso do automóvel. desde que haja soluçồes alternativas. Desta forma. tem-se no Brasil o ônibus como sinônimo de transporte coletivo urbano, sendo esta a principal tecnologia utilizada para este fim.

O ônibus é provavelmente o modo de transporte mais difundido em todo o mundo. Este fato está relacionado com sua flexibilidade. sua capacidade de adaptar-se a diferentes demandas, sua tecnologia simples, sua facilidade em trocar de rotas ou criar novas rotas, além dos baixos custos de fabricaçåo, implementação e operação quando comparados à outros modos. Tudo isto faz com que o ônibus seja, atuaimente, o principal modo de transporte público disponivel em cidades de pequeno e médio portes. além de um importante complemento para os modos de alta capacidade nas grandes cidades (BALASSIANO, 1997: SILVA \& FERRAZ, 1991).

Segundo a MERCEDES BENZ DO BRASIL (1987), as causas do ônibus ter sido tão amplamente empregado com relação à outras modalidades de transporte são:

- Requer menor investimento inicial do que os sistemas sobre trilhos;

- Por sua natureza. ser meio essencial de transporte;

- Plexibilidade na adequação de itinerários e expansåo de trajetos;

- Rapidez na implantaçào:

- Poder transportar demandas elevadas e atingir altas velocidades, desde que em condiçỏes prioritárias;

- Valor de revenda alto: 
- Ser operado na maioria dos casos pela iniciativa privada e apenas regulamentado por órgấos públicos.

Desta maneira, o onibus está integrado na configuração da maioria das cidades brasileiras como meio de transporte coletivo essencial. Estima-se que ele atenda cerca de 95\% dos deslocamentos urbanos (trabalho, escola, compras, lazer e outras atividades) por transporte público no país, considerando-se ai também o trólebus (ANTP, 1997a).

Os elementos que serão vistos a seguir são caracteristicas físicas, das quais o sistema de transporte depende, em maior ou menor grau, para a sua operação.

\subsubsection{Vias de ônibus}

O bom desempenho do transporte coletivo é uma condição imprescindivel para a eficiència da cidade e para a qualidade de vida. As vias utilizadas pelos ònibus devem ter como objetivo proporcionar melhores condiçôes de cículação para os veículos de transporte coletivo. Dependendo das caracteristicas de cada local, podem ser organizadas de acordo com vários níveis de prioridade (ANTP, 1997a). Segundo a ANTP (1997a) os principais objetivos devem ser:

- Possibilitar a reduçào do tempo de viagem, dando prioridade à modalidade de maior capacidade de transporte de pessoas;

- Racionar e reorganizar o serviço de ônihus, em função da reduçāo de investimentos na quantidade de veiculos requeridos;

- Diminuir o consumo de combustiveis, com reduçăo e otimizaçào do custo operacional;

- Melhorar as condições do serviço prestado, permitindo o estabelecimento de nova imagem dos serviços oferecidos à populaçà, principalmente se as 
medidas forem ligadas a melhorias nos veiculos, modelo operacional e de geståo, etc:;

- Criar eixos preferenciais para o transporte coletivo, com tratamento adequado e atendendo as necessidades de demanda:

- Proporcionar melhor qualidade ambiental nos corredores de transporte coletivo e nas áreas adjacentes;

- Garantia de prioridade para o transporte público no caso de vias congestionadas; $\mathrm{e}$

- Melhorias das ligaçőes por transporte coletivo entre regiões da cidade.

Nas grandes cidades brasileiras a maioria da populaçấo utiliza o ônibus para seus deslocamentos rotineiros para ir ao trabalho, escola, compras, lazer e outras atividades urbanas. Para se alcançar uma boa qualidade do serviço de transporte coletivo, c essencial que nas vias onde ocorrem grandes tluxos de ónibus e de concentração de passageiros sejam implementadas medidas de priorização para circulaçẩo dos ônibus. Desta forma, os ôníbus circulam com maior fluidez, livres de congestionamentos e da disputa do espaço viário com o tráfego em geral.

\subsubsection{Rotas}

As linhas de transporte público devem passar pelos principais pólos de atraçào de viagem da área que é destinada a atender, assim como proporcionar uma cobertura satisfatớria das àreas habitadas. Locais como shopping centers, distritos industriais. terminais de transportes, escolas, universidades, centros esportivos, etc., localizados na área de atendimento, são pontos de passagem quase sempre obrigatórios. O itinerảrio da linha deve, também, permitir que todos os habitantes, de uma determinada área coberta pelo sistema de transporte público, possam utilizá-lo com percursos realizados a pé dentro de limites toleráveis. 
Em funçào do atendimento oferecido e do itinerário desenvolvido, as linhas de ônibus recebem uma classificação. Cada tipo de linha se ajusta melhor a um determinado padrào de atendimento. Conhecer o comportamento da demanda a ser atendida é imprescindivel para determinar o tipo de linha de ônibus que apresentará os melhores resultados operacionais.

De acordo com SILVA \& FERRAZ (1991), os tipos mais usuais de linhas de onibus são:

- Radial: realiza a ligação entre pontos da cidade e o centro da cidade. $\dot{\mathrm{E}}$ indicada para atender grandes fluxos de passageiros, tendo como destino final o centro da cidade:

- Diametral: realiza a ligação entre bairros diametraimente opostos passando pelo centro. Para cidades de pequeno e médio porte é o melhor tipo de linha. pois evita transferências e o pagamento de duas ou mais passagens;

- Circular: opera continuamente, sem ponto inicial ou final podendo passar ou nâo pelo centro da cidade; e

- Interbairro: faz a ligaçầo entre sub-centros de bairros, não passando pelo centro da cidade.

Na claboração da rede de transporte público em cidades médias, FERRAZ (1997) recomenda a observação de quatro aspectos, para alcançar uma eficiència satisfatória do sistema:

- Evitar a sobreposição das zonas de influência de duas ou mais linhas, com exceçâo da área central. ou quando uma das linhas cruzar a zona de influência de outra com o objetivo de atingir áreas mais afastadas;

- Definir adequadamente as zonas de influência de cada ligaçào. com a finalidade de evitar uma excessiva ociosidade na oferta nos periodos de baixo movimento;

- Estabelecer, para cada itincrário, o caminho mais direto possivel e, de preferẻncia, com os itinerários de ida e volta na mesma via ou em vias 
próximas. Devem ser evitados itinerários sinuosos $\mathrm{e}$ tortuosos, pois os traçados diretos levam, quase sempre, a um desempenho mais eficiente e eficaz do serviço, bem como são bem mais faceis de screm compreendidos e usados pelos usuários; $e$

- Utilizar linhas diametrais sempre que houvet equilibrio na demanda e significativo número de viagens.

\subsubsection{Pontos de Parada}

Os locais de embarque e desembarque de passageiros dos ônibus, localizados nos passcios públicos, são chamados, de um modo geral, de pontos de parada. Os pontos de parada sầ de grande importância para a operaçào e imagem de um serviço de transporte público: neles os usuários tếm o primeiro contato com a rede de transporte público e seu espaçamento determinará o desempenho operacional das linhas e influenciarà nos custos de operaçä́n.

Como os pontos de parada sâo componentes importantes na determinação da capacidade de um sistema de transporte público, é fundamental que sejam localizados e dimensionados adequadamemte. Os pontos podem ser simples, onde todos os ônibus param; seletivos, onde em cada ponto so param algumas linhas pré-definidas: e múltiplos. quando operam ònibus em comboios de dois ou mais veículos:

A identificaçăo dos pontos de parada pode ser feita com marcas em postes de energia ou telefone, com a colocação de marco especifico (geralmente um pequeno poste com ou sem placa contendo dizeres) e com a colocação de abrigos. Uma maneira de se oferecer maior conforto aos usuários durante a espera é através da colocação de abrigos nos pontos de ònibus. Se o local tiver banco para sentar, a comodidade é ainda maior.

A não sinalizaçăo dos pontos de parada, fato comum nas regióes periféricas de algumas cidades, nåo prejudica diretamente os usuários cativos, que sabem onde os ònibus param. Refletem, no entanto, uma certa desorganizaçăo do serviço. Para os 
usuários não cativos a sinalização clara dos pontos é fundamental na utilização do transporte coletivo.

Os pontos de parada exigem soluções construtivas resistentes e funcionais $\mathrm{e}$ ao mesmo tempo devem renovar e enriquecer esteticamente o meio urbano, dando identidade visual à rede de transporte público. O ponto de parada pode requerer. além do abrigo, iluminaçào própria, banco. lixeira, mapas e informaçð̃es operacionais sobre a rede de transporte e o órgåo gestor (ANTP, 1997a).

Segundo a ANTP (1997a), para a implantação de pontos de parada devem ser considerados os seguintes:

- Colocar pontos de parada nos locais mais convenientes para os usuários e que ofereçam boas condiçoes de segurança na travessia; todavia, evitar coloca-los imediatamente após cruzamento importante. em posição inadequada em relação ao semáforo, em locais de rampa acentuadas ou junto à entrada de garagens e estacionamentos:

- Em vias expressas ou vias de alta velocidade, colocar baias para a parada dos ônibus, nos pontos de parada; quando o volume de ônibus for elevado. colocar pavimentos rigidos junto aos pontos:

- Cobrir o ponto de parada para a proteça contra intempéries e pavimentar e iluminar a calçada:

- Dimensionar o ponto de parada para o volume máximo de demanda prevista para o local (às vezes nâo basta cobrir apenas o espaço da porta de embarque): adotar soluçōes modulares que possam ser agrupadas segundo a dimensåo necessária do ponto de parada:

- Dotar o ponto de parada de informações sobre as linhas de onibus que passam no local e também outras informaçôes de interesse dos usuários;

- Prever a exploraçào publicitária nos pontos de parada como forma de ressarcimento dos custos de implantaçào e manutençào dos abrigos. Entretanto, o contrato de exploração comercial deve prever a comercialização 
de toda a rede de pontos, incluindo ai aqueles instalados em regiócs periféricas de menor poder aquisitivo, ou pontos de menor afluxo de usuários.

Vale ressaltar que a cidade deve adotar um padrão de ponto de parada e o que o mesmo deve se estender ás regiões periféricas, nảo bastando o tratamento apenas dos pontos localizados na regiâo central. Do ponto de vista da qualidade do serviço para os usuários, os pontos de parada devem possuir, pelo menos, algumas instalações consideradas essenciais. A tabela 2.2 apresenta o que deve ser colocado nos pontos de parada para um atendimento minimo, razoável e bom aos usuários. 
TABELA 2.2 - Instalaçōes necessárias à ponto de parada.

\begin{tabular}{|c|c|c|c|}
\hline Instalaçōes necessárias ao ponto de parada & $\begin{array}{l}\text { Exigências } \\
\text { minimas }\end{array}$ & $\begin{array}{c}\text { Ponto } \\
\text { desejável }\end{array}$ & $\begin{array}{l}\text { Instalaçōes } \\
\text { completas }\end{array}$ \\
\hline \multicolumn{4}{|l|}{ Informaçoes ao passageiro } \\
\hline Identificação caracteristica de ponto de parada & (8) & (-) & (2) \\
\hline Identificaçăo das linhas - nome e número/código & 8 & $\Theta$ & 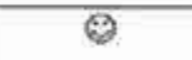 \\
\hline Denominação do ponto & & (-) & (4) \\
\hline Tabela de horários & & (9) & 9 \\
\hline Croquis de itinerários & 8 & () & (2) \\
\hline Relógio & & (9) & (2) \\
\hline Plano com rede de linhas & & & (9) \\
\hline Tarifas & & $\Theta$ & (9) \\
\hline Tipos de serviço & & & Q \\
\hline Mapa da regiăo adjacente & & & 9 \\
\hline \multicolumn{4}{|l|}{ Equipamentos } \\
\hline Proteçåo para o tempo (cobertura, paredes laterais) & & (⿻) & (4) \\
\hline fluminaçào & & & (2) \\
\hline Assentos & & & (2) \\
\hline Telefone público & & & (8) \\
\hline Depósito para lixo & 6 & (2) & 8 \\
\hline Caixa de correio & & & 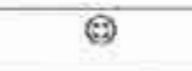 \\
\hline Espaço para propagandin & & (⿻) & $\theta$ \\
\hline
\end{tabular}

Fonte: MERCEDES BEN/ DO BRASLL (1987). 


\subsection{Sistemas de Informações aos Usuários}

Os sistcmas de informações sảo uma ferramenta de diảlogo com o público. Permitem extrair do conjunto de informaçoes relativas a uma rede, aquelas que correspondem a uma necessidade especifica (por exemplo: tempo de espera) ou personalizada (por exemplo: itinerário de uma linha) e ainda podem garantir um aumento da qualidade do serviço of erecido ao passageiro (SILVA \& LINDAU, 1997).

\subsubsection{Principais Funçōes}

Segundo CAR \& PELL.S' (1995) apud SILVA \& LINDAU (1997), os serviços de informações aos usuários do transporte coletivo têm as seguintes funçóes:

- Promocional - garantir mobilidade e melhorar a imagem do transporte público;

- Educacional - prestar informaçôes sobre como utilizar o transporte público e as regras envolvidas no seu uso;

- Operacional - auxiliar no planejamenta de viagens, melhorar acessibilidade e informar sobre alteraçōes na programação:

- Moderação - aliviar as ansiedades dos usuários e aumentar o controle, por parte do usuário. sobre sua jomada.

\subsubsection{Comunicação com o Público}

As informaçōes sobre o transporte público devem ser de fäcil acesso à população. Elas podem ser afixadas nos pontos de parada. em painéis colocados em terminais,

\footnotetext{
'CAR. JD.: PELLS, S, (1995) t/set's Reactions to Infopoints: The Aplication of Touch Screen Technology to Passenger Information. In Proceodings of PTRC Summer Annual Meeting, London: PTRC, p. 73-85, apud SII.VA. D.M. IINDALI, L.A. (1997), Potencial dos Sistemas Avançados (APTS) no Transporte Colecivo Urbeno por Onibus. Anais do XI Congresso de Pesquisa e Ensino cm Trunsportes - ANPET, Rio de Janeito, v1. R. 510.518
} 
através de folhetos ou ainda ser veiculada fora do sistema, como no caso do uso do rádio, do telefóne c da televisào.

Uma informaçåo importante é o destino de cada viagem realizada c o nủmero da linha. Esta informaçâo deve ser colocada na parte superior da frente dos veículos, num compartimento denominado de caixa de vistas ou caixa de itinerário. Outra informação comumente veiculada nos ônibus é o valor da tarifa vigente, em geral mediante adesivo colocado na parte inferior do vidro frontal. No interior dos veiculos, na parte lateral superior é usual se colocar informaçôes relativas aos itinerários, integraçóes com outras linhas ou modos, cte.

Nas estaç̄es e pontos de paradas devem ser colocados os nomes e os números das linhas que por ali passam. mapas simplificados com as rotas $\mathrm{e}$ os pontos de integraçâo do sistema de transporte público, tarifas, etc. Nos teminais e estaçòes mais imponantes devem ser colocados mapas gerais do sistema de transporte público e balcòes para informaçòes verbais e distribuiçāo de folhetos com informaçōes impressas contendo os horários e mapas simplificados das rotas. A distribuição periódica de folhetos, contendo informaçōes sobre horários e map̧as das linhas, é de grande importància para usuários nào cativos. Embora de menor relevancia para os passageiros cativos, nåo deixa, no entanto, de ser útil e aumentar o conhecimento do sistema.

Os próprios motoristas, cobradores e fiscais devem ser treinados para prestar informaçòes aos usuários quandó solicitados. A disponibilidade de um nùmero especial de telefone para informaçồes e reclamações também é importante.

\subsubsection{Aplicaçöes}

Nesta seção pretende-se mostrar algumas aplicaçôes de sistemas de informaçōes para usuários de transporte pủblico que foram implantados ou estấo em processo de implantaçảo. Para isto recorreu-se a programas de consultas disponiveis em disquetes. 
artigos internacionais e a uma pesquisa rảpida realizada pela ANTP (1997b). Nẫo é objetivo desta seção cobrir exaustivamente estas aplicaçỏes. apenas mostrar alguns sistemas que foram implementados com sucesso.

Na Europa, os serviços de informaçôes aos usuários estão bastante difundidos. É o caso do ARIdisc, programa de computador que contém todos os detalhes requeridos para fazer uso de serviços domésticos de passageiros na Bélgica, via trem, ou daqueles serviços que conduzirão para os destinos principais da Europa, O sofiware abrange dois: módulos, a saber; horários e tarifas. No módulo de horários, o usuário poderá encontrar informações referentes à estação de partida, estação de chegada, a data da viagem e o tempo requerido da partida e da chegada. O programa oferece opçóes de escolha dentre as que se apresentam. Agora, se o usuário estiver interessado em saber o preço da viagem escolhida por ele. terá que optar pelo módulo de tarifas, onde encontrará informaç反́es referentes à passagens de ida e ida-volta, primeira ou segunda classes, a redução que o passageiro pode usufruir e a tarifa paga pela viagem ao se viajar sozinho ou acompanhado.

O trabalho desenvolvido por CHAPLEAU et al. (1996) apresentou o sistema conhecido como AUT - OBUS, que fornece, por telefone, aos passageiros escollas de rotas ótimas na rede de transporte público da STCUM (Sociedade de Transporte da Comunidade Urbana de Montreal). Um Sistema de Informaçōes Geográficas especial foi desenvolvido para processar as origens e destinos, tendo como base as especificações dos usuários. A determinação da melhor rota é calculada levando-se em consideraçâo algumas funçôes de impedância, tais como: caminhada, tempo no veiculo. espera. transferências, tarifas, etc. Também foi necessário levar em consideração a geometria da rede de transportes, a velocidade comercial. dias da semana ou finais de semana, 0 tempo de viagem, o headway, dentre outras informaçðes necessárias. Para uma rede de transporte público do tamanho da de Montreal, constituida de 16.000 pontos de ônibus. 230 linhas de ônibus, e uma rede de pedestre de 80.000 links e 28.000 nós, o tempo de cálculo da rota ótima entre origem e destino fornecidos é menor do que 2 segundos com um tipico computador pessoal com um processador Pentium. 
No Brasil. já se tem conhecimento de alguns serviços de informaçôes aos usuários. Isto pode ser percebido numa pesquisa realizada recentemente pela ANIP (1997b) junto aos órgãos gestores dos transporte públicos, sobre a disponibilidade de sistemas permanentes de informaçðes aos usuários de ónibus e suas características. A pesquisa foi aplicada em 24 capitais. 9 regiôes metropolitanas e o Distrito Federal, além de 42 cidades de médio porte em todas as regiōes do Brasil.

Dos 34 questionários elaborados para a pesquisa e aplicados nas capitais e regið̄es, houve 23 respostas positivas sobre a existência de sistemas permanentes de informaçôes aos usuários e 11 questionários nào obtiveram respostas. Em 16 casos, os respondedores asseguraram a existência de um telefone a disposiçào dos usuários para informações básicas e outro para reclamações; e nos outros casos. apenas o telefone para reclamaçỏes. Com relação a existência de mapas e horários das linhas nos pontos de parada ou terminais, houve apenas 8 respostas positivas: em dois casos (regiån metropolitana do Recife $\mathrm{c}$ a cidade de João Pessoa), os respondedores afirmaram a existência de informaçôes nos pontos e nos terminais e nos outros casos apenas nos terminais. Quanto a outros sistemas de informações, a cidade de Fortaleza disse distribuir panfletos quando novas linhas de ônibus são criadas e Belo Horizonte informou a existẻncia de telefone para solicitar intervenção no transporte ou no trânsito.

No caso das cidades de médio porte foram enviados 42 questionários, dentre os quais houve 25 respostas positivas sobre a existência de sistemas permanentes de informaçòes aos usuários de ònibus: 7 questionảrios apresentaram respostas negativas e 10 questionários não tiveram respostas. Em 16 casos, os respondedores disseram manter um telefone para informaçôes básicas aos usuários e outro para reclamações; em sete casos. apenas o telefone para reclamaçōes e em outros dois apenas o telefone de informaçôes. Sobre a existência de mapas e tahelas de horários das linhas nos pontos, houve apenas cinco respostas positivas; em apenas um caso (Niterói - RJ), o respondedor disse que existem informaçỏes tanto nos pontos como nos terminais e, nos demais casos, ou nos pontos ou apenas nos terminais. 
Com relaçẫo a outros sistemas de informaçōes, Campinas - SP dispõe de atendimento em postos nos terminais; informaç̋es afixadas no interior dos ónibus podem ser encontradas em Juiz de Fora - MG; disponibilidade dos horários das linhas no terminal central em Novo Hamburgo - RS; caixa de sugestóes em Ribeirào Preto SP. Em implantação, podem ser citados: livro de bolso com itinerários e urna de sugestōes (Santo André - SP) e itinerảrios e horários nos principais pontos de parada (Uberaba-MG). 


\section{SISTEMA DE INFORMAÇÕES GEOGRÁFICAS}

Neste capitulo faz-se um breve histórico dessa tecnologia; define-se, de maneira geral, o que é Sistema de Informał̧ôes Geográficas e suas caracteristicas; enumeram-se os principaís componentes de um S/G: apresentam-se as técnicas de representação de um SIG; mostra-se o espaço que está sendo conquistado pelo SIG no planejamento urbano: faz-se um estudo do estado da arte das principais abordagens nos trabalhos já realizados nas diversas áreas da Engenharia de Transportes s, por ültimo, introduz-se o software de SIG que será utilizado neste trabalho como ferramenta expecifica de analise de transporte.

\subsection{Introdução}

O primeiro Sistema de Informações Geográficas (SIG) surgiu no Canadă, na década de 60 , e mostrava uma necessidade que as agências governamentais voltadas para o meio ambiente daquele pais tinham, jả àquela época, de mapear suas reservas naturais. Outro objetivo era efetuar múltiplas análises a respeito do seu meio ambiente como um todo, sendo necessário o processamento de uma grande quantidade de dados criados pelo inventário de terras canadense (CALIJURI \& ROHM, 1994). Em seguida foram desenvolvidos os sistemas de New York Landuse and Natural Resources Information Systems (1967) e Minnesota Land Management Information System (1969). A aplicação de tais sistemas limitou-se às agências federais e estaduais do governo americano e canadense, em virtude dos custos elevados e dos problemas de implementação (TEIXEIRA et al., 1992). 
Segundo CÂMARA et al. (1996), na década de 70 desenvolveram-se fundamentos matemáticos voltados para a cartografia. Surgiu, então, a topologia aplicada, permitindo análises espaciais entre dados cartográficos. Até então, somente grandes organizaçðes tinham o privilégio de utilizar SIGs em sistemas de grande porte. Na década de $80, \mathrm{com}$ a popularizaçảo e barateamento das estaçōes de trabalho, computadores pessoais e baneos de dados, o uso de SIG foi difundido com a incorporaçăo de muitas funç̧es de análise espacial.

Acrescentam CĀMARA et al (1996) que, para o final da década de 90, podese prever o surgimento de uma nova geração de SIGs, baseada em bibliotecas digitais geográficas ou centros de dados geográficos. caracterizada pelo gerenciamento de grandes bases de dados geográlicos, com acesso através de redes locais e remotas, públicas ou privadas. $\Lambda$ nova geração pode ainda ser vista como 0 desenvolvimento de sistemas orientados à troca de informaçốes entre uma instituição e os demais componentes da sociedade.

\subsection{Definições e Características}

Um Sistema de Informações (jeográficas pode ser definido como sendo "uma coleçẫo organizada de hardware, software, dados geográlicos e pessoal, projetado para, eficientemente, capturar, armazenar, atualizar, manipular, analisar e apresentar todas as formas de informaçōes reférenciadas geograficamente" (CALIJURI \& RÖHM, 1994).

Para uma melhor compreensão da definição citada acima, pode-se considerar o SIG como um tipo de Sistema de Informaçào, que envolve, de forma sistêmica e interativa, tecnologia, banco de dados e pessonl, sendo capaz de realicar análises espaciais, armazenar, manipular, visualizar e operar dados georeferenciados para obtenção de novas informações (DANTAS et al., 1996). A figura 3.1 ilustra a interação dos quatro elementos mencionados anteriormente. 


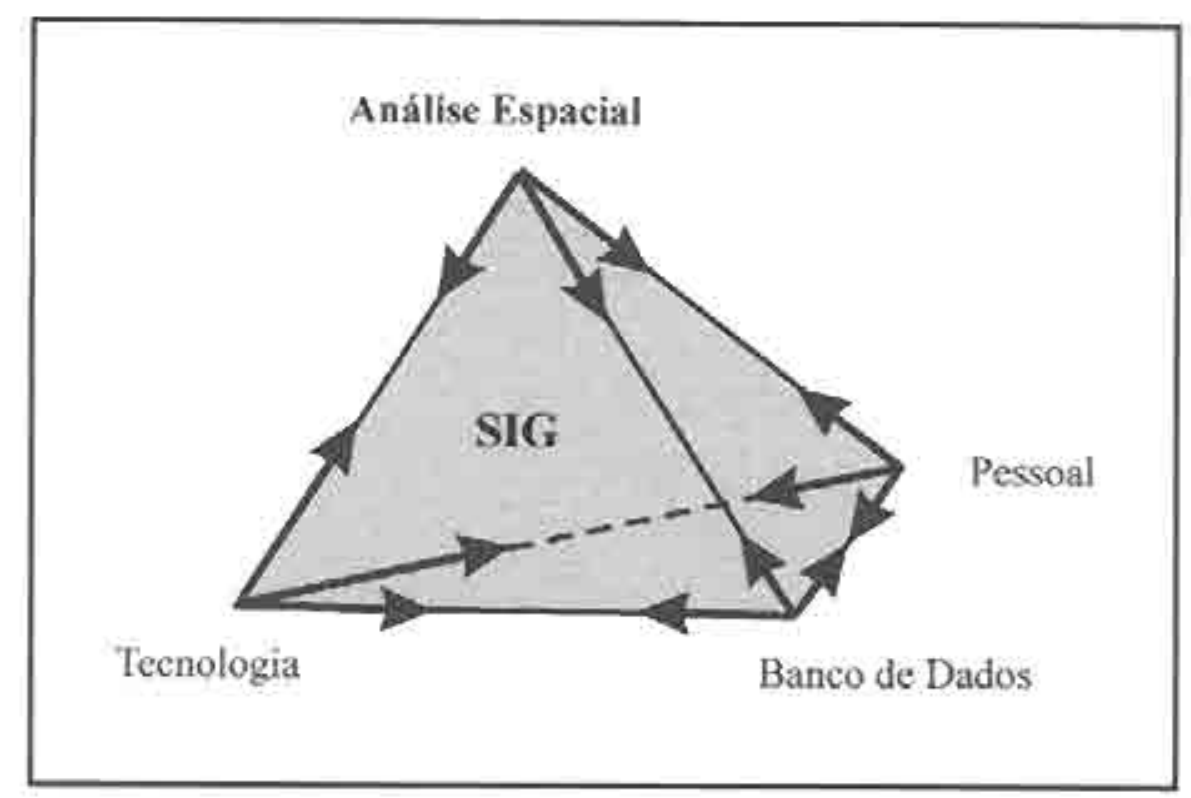

FIGURA 3.1 - Elementos de um Sistema de Informaçōes Geográficas.

Fonte: DANTAS et al. (1996).

Cabe aqui destacar a importância da topologia na concepção de um SIG. A topologia é a relaçåo espacial entre objetos. Por exemplo: para encontrar a rota ótima entre dois pontos é necessário que exista uma lista de arcos conectados.

Segundo RAMALHO \& CALIJURI (1994), as principais caracteristicas de um Sistema de Informaçōes Geográficas são:

- Integrar. numa única base de dados. informaçōes espaciais provenientes de dados cartográficos, dados de censo e cadastro urbano e rural. imagens de satélite. entre outros:

- Combinar as várias informações, para gerar mapeamentos derivados; $\mathrm{e}$

- Consultar, recuperar, manipular, visualizar e plotar o conteúdo da base de dados.

Esta caracteristica de integrar, numa única base de dados. informaçòes geográficas provenientes de dados, permite ao SIG. por exemplo. produzir mapas temảticos que refletem as informaçøes associadas às entidades representadas. A 
figura 3.2 representa um mapa temático produzido por um S1G. Neste exemplo, as linhas de ônibus foram diferenciadns através de cores de acordo com o headway (intervalo entre veiculos) predominante em cada uma delas.

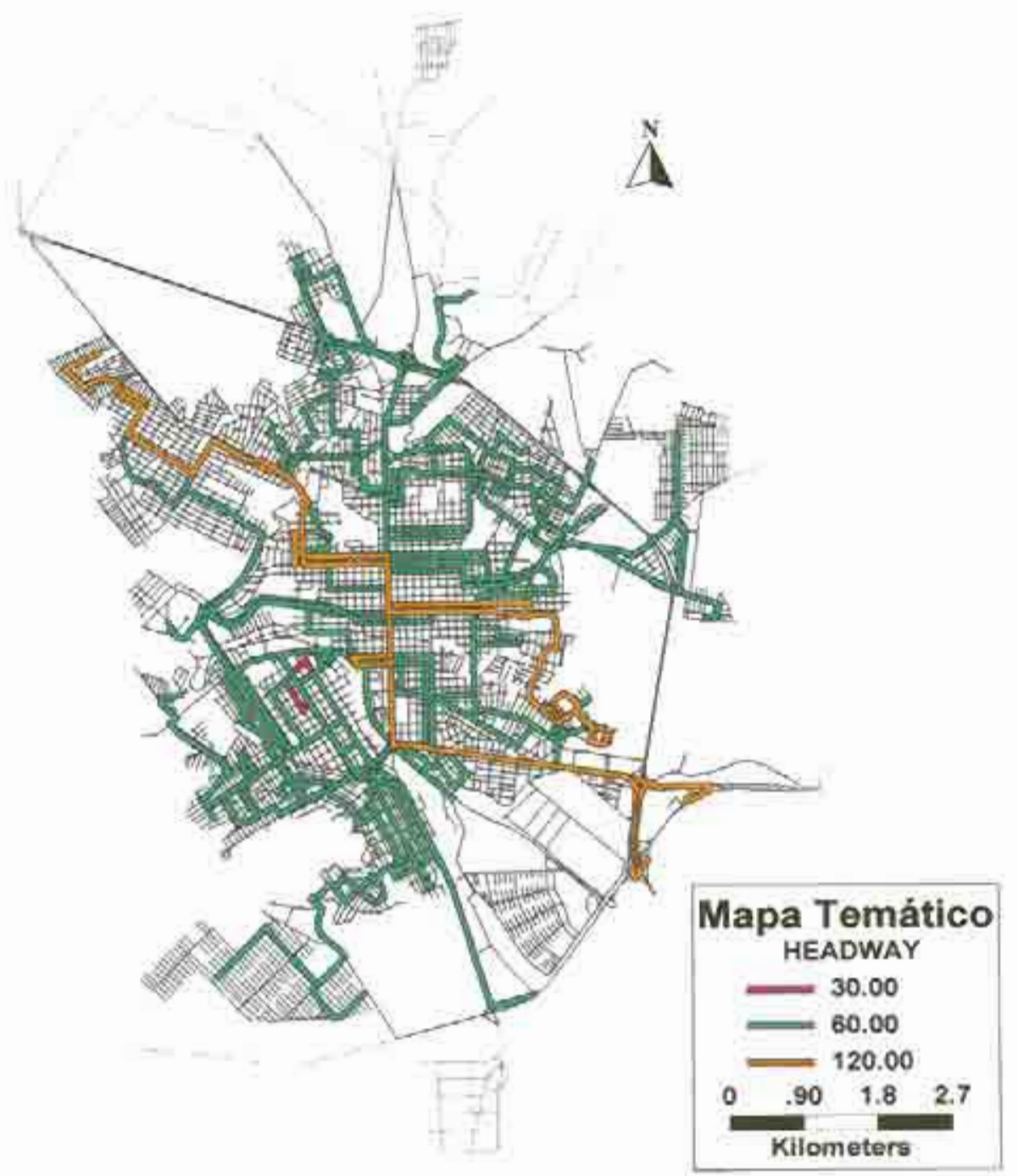

FIGURA 3.2 - Mapa temático gerado por um SIG. 


\subsection{Componentes de um SIG}

Para TEIXEIRA et al. (1992), um SIG pode ser visto como um sistema composto por um banco de dados, por um conjunto de programas (soffware) dedicados à execução de operaçdes sobre os dados e equipamentos (hardware).

$O$ banco de dados constitui a parte essencial da composição de um SIG. Estes dados são constituidos de uma coleção de mapas e informaçōes digitais relacionados às feicoes da superficie terrestre, sendo o SIG composto por dois elementos: um banco de dados espaciais, que descreve as caracteristicas da superficie do terreno (forma e posiçăo) e um hanco de dados de atributos. que descreve as qualidades destas caracteristicas (CALIJURI \& RÖHM, 1994).

$O$ banco de dados é composto por programas que gerenciam os dados, ou seja, organizam os mesmos com o objetivo de agilizar a procura para aplicaçỏes das operaçôes espaciais. Estes programas permitem manusear dados. atualizá-los ou aiterá-los, acrescentar outras informaçỏes, trabalhar com parte delas em função do problema em questão. No caso especifico do planejamento de transportes, as informaçס̄es tipicamente necessárias sào. segundo KAGAN et al. (1992);

- Dados socio-econômicos e demográficos de população (habitantes. empregos, renda, produçåo industrial e agricola, etc.):

- Dados sobre características do uso e ocupação do solo;

- Dados descrevendo a oferta de transportes:

- Dados sobre a demanda por transportes.

O gerenciamento do banco de dados é a principal qualidade dos SIGs, pois é através desta capacidade do sistema que a interação do usuário com as informações é permitida. Como dizem CALIJURI \& ROHM (1994): "O cerne do sistema é o banco de dados que, em sintese, é uma coleção de mapas e de informações associadas na forma digital" .

Segundo TEIXEIRA et al. (1992), os operadores espaciais são um conjunto de programas que atuam sobre a base de dados, produzindo as informações 
requeridas pelos usuários. As funções dos operadores podem ser divididas em préprocessamento e processamento digital.

As funçòes de pré-processamento permitem alterar os dados como um todo para atingir os seguintes objetivos:

- Conversão entre tipos de arq̣uivos;

- Mudança de escala;

- Mudança de estrutura (raster - vetorial):

- Mudança de projeçào cartográfica;

- Uniåo de bases de dados; entre outros.

Já as funçòes de processamento visam extrair informaçôes da base de dados ou criar novas informaçôes de acordo com as necessidades dos usuários. Entre estas funções destacam-se:

- Aualização de dados:

- Cálculo de áreas;

- Cálculo de distâncias (menor distảncia entre dois pontos, rota mais curta ou mais rápida);

- Cálculo de perímetro:

- Cálculos estatísticos:

- Classificaçẫo dos dados:

- Cruzamento entre planos:

- Filtragens espaciais;

- Localizaçăo de uma entidade e listagem de seus atributos:

- Operaçōes aritméticas entre planos;

- Posicionamento, etc.

Outro aspecto importante é o hardware. Os SIGs podem operar $\mathrm{em}$ microcomputadores, Workstations, minicomputadores e mainframes.

O componente hardware se constitui de todos os equipamentos necessários para desempenhar a função de coleta de dados na forma digital, processamento e 
apresentaçào das informaçōes. De maneira geral, a maioria dos sistemas admite vários periféricos, sendo os mais comuns: mesa digitalizadora, mouse, vídeo colorido, impressoras e plotters. Os principais equipamentos periféricos utilizados em SIGs sâo os seguintes:

- Entrada de dados:

- Teclado: Entrada de atributos, comunicaçào com o usuário;

- Mouse: Comunicaçăo do usuário com o software;

- Mesa digitalizadora: Entrada de dados grálicos, comunicação do usuário com o soffware;

- Scanner: Entrada de dados gráficos;

- Restituidores: Integraçåo com fotointerpretação:

- Câmeras de vídeo: Entrada de dados gráficos.

- Armazenamento:

- Discos flexiveis: Armazenamento temporário ou permanente de dados de acordo com a capacidade;

- Unidades de fita: Armazenamento de grande quantidade de dados. geralmente por longo periodos;

- Disco rigido: Armazenamento, para acesso rápido, de dados e programas.

- Saida:

- Monitores de video: Apresentação temporária dos dados gráficos e numéricos, comunicação com o sistema;

- Plotters e impressoras: Apresentaçāo dos dados gráficos, relatónios e tabelas.

Segundo SULA et al. (1994), para a utilização de Sistema de Informações Geográficas como ferramenta de planejamento, deve-se estabelecer, inicialmente, $\triangle$ dominio espacial do problema, ou seja, deve-se definir os dados (entes e atributos) necessários ao estudo, sua forma de mensuraçâo e as fontes de dados, que podem ser:

- Fontes primárias - obtidas diretamente do mundo real através de: 
- Levantamentos de eampo (topográficos, geodésicos, cadastrais, ete.);

- Produtos de sensoriamento remoto (fotografias aéreas, imagens orbitais);

- Recenseamentos;

- Videos.

- Fontes secundárias - desenvolvidas a partir de fontes primárias:

- Mapas.

Para serem introduzidos nos computadores, os dados sofrem processo de codificação e de digitalização (via mesa digitalizadora, teclado, scanner, etc.). Esta fase é uma das mais importantes do trabalho, pois nela se estabelece a qualidade. precisão (nível de resoluçăo) e confiabilidade do produto final. Define-se nesta etapa a viabilidade operacional do sistema. em função do volume de dados, do tempo e da capacidade do equipamento disponivel.

As mesas digitalizadoras são dispositivos de entrada que possuem sob sua superficie de trabalho uma rede magnetizada. que envia para o computador as coordenadas x e y de um cursor (mouse) movimentado pelo usuário. A digitalizaçâo de mesa ainda é o modo mais utilizado para a entrada de dados a partir de mapas existentes. É um processo usualmente caro e demorado. envolvendo os passos de digitalizaçảo de linhas, ajuste de nós, geração de topologia e rotulação (identificação) de cada dado geográfico. O teclado permite a entrada de atributos e a comunicaçáo com o usuário. A digitalização ótica por instrumentos de varredura (scanners) vem sendo utilizada de forma cada vez mais intensa. A escolha pelo uso destes equipamentos está relacionada à rapidez pela qual a geometria do mapa é capturada e ao custo. 


\subsection{Estruturas de dados}

Existem duas técnicas fundamentais de representação de dados gráficos $\mathrm{cm}$ um SIG: raster e vector ou vetorial.

O modelo vetorial se caracteriza pela locaçāo precisa dos objetos geográficos atraves de coordenadas, sendo os objetos representados por pontos, linhas ou poligonos. $O$ formato vector tem como principais vantagens a sua excelente precisăo matemática, fazendo com que os contornos dos objetos sejam hem definidos, e a economia de espaço para armazenamento de informaçōes. Estas qualidades do formato vector o tomam mais recomendável para o uso na área de cartografia. Seu

principal ponto fraco é ser menos eficiente em promover operaçỏes algébricas e sobreposiçăo de mapas, o que pode ser feito de maneira bastante rápida na estrutura raster.

No formato raster, o espaço geográfico é dividido segundo um sistema de células retangulares, normalmente quadradas, sendo o conteúdo de cada célula descrito pelo banco de dados. Isto significa que a informação geográfica continua no espaço é discretizada perdendo em exatidăo e detalhes, mas ganhando em facilidade de manipulação no ambiente computacional, uma vez que a estrutura de armazenamento dos dados por matrizes é adequada a estrutura da matemática computacional. Alćm disso, como as imagens de sensoriamento remoto utilizam também a forma matricial para armazenamento de dados, sua interação com sistemas desse tipo é perfeitamente viável. No entanto, esta facilidade impede a representação adequada de elementos geográficos menos homogêneos, como rodovias, infraestrutura de água, esgoto, rede elétrica, teletônica, etc.

A diferença básica entre as estruturas raster e vector reside no modelo de espaço adotado em cada uma. Enquanto a estrutura vector considera o espaço cominuo, seguindo postulados da Geometria Euclidiana. a estrutura raster divide o espaço em elementos discretos. A figura 3.3 mostra as estruturas raster e vector. obtidas a partit de um mapa original. 
As grandes desvantagens do modelo raster sâo o tamanho dos arquivos gerados, tornando inviável sua utilização para áreas extensas, e a baixa capacidade de trabalho com baneo de dados do tipo relacional para representação espacial dos atributos adicionais, uma vez que a associaçåo de atributos acontece somente a classes do mapa. No entanto, o desenvolvimento desses tipos de sofrware está caminhando para dar maior suporte a integraçăo de banco de dados relacional.

Devido à afinidade entre a lógica da representação vetorial e a tradicional produção de mapas, os sistemas vector são muito populares em aplicaçỏes municipais, garantindo a produçào de mapas e, predominantemente, o gerenciamento de banco de dados.

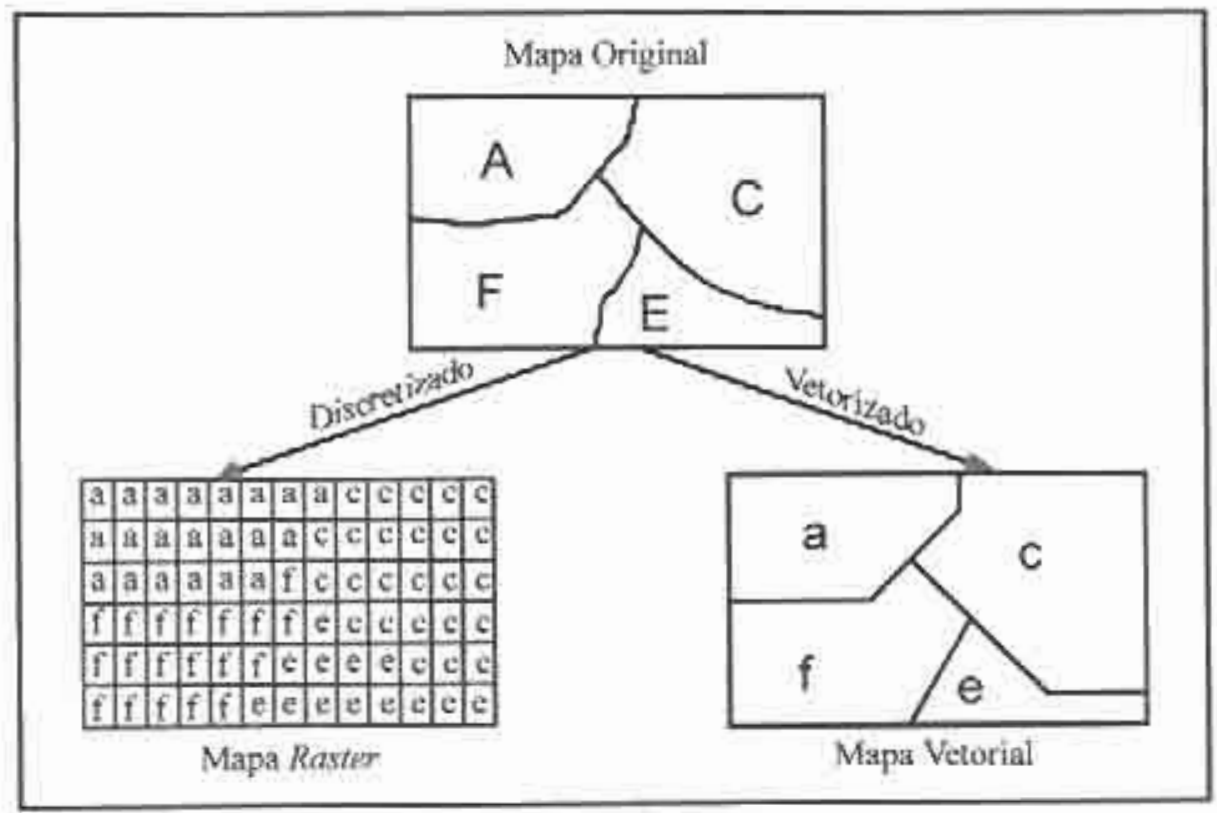

[IGURA 3.3 - Estrutura raster e vector.

Fonte: RUSA (1989) apud TEIXEIRA et al. (1992). 


\subsection{Modelos de Utilização de SIGs}

Segundo DANGERMONT ${ }^{2}$ (1990) apud CALIJURI \& ROIIM (1994), as justificativas para a utilização de SIGs são:

- Os dados săo mantidos em um formato fisicamente compactado (arquivos magnéticos):

- Os dados podem ser mantidos e extraidos a um custo menor por unidade de dado manipulada;

- Os dados podem ser acessados a uma velocidade muito maior;

- As ferramentas computacionais permitem maior flexibilidade de manipulação, incluindo medidas e sobreposição de mapas, transformações, gráficos diversos e gerenciamento de hanco de dados:

- As informações gráficas c não grảficas (atributos) podem ser fundidas c manipuladas, simultaneamente, de maneira relacionada;

- Podem ser realizados testes analiticos de modelos conceituais de modo rápido e preciso (por exemplo, susceptibilidade do solo à crosão, capacidade de suporte do solo, etc), facilitando avaliações cientificas e técnicas em grandes áreas, em curto periodo de tempo;

- As análises de mudanças podem ser efetuadas em dois ou mais períodos de tempo;

- As ferramentas de desenhos gráficos interativos e automatizados podem ser aplicadas no desenvolvimento de mapas e de desenho cartográfico; $\mathrm{t}$

- Certos tipos de análises podem ser realizadas muito mais eficientemente em termos de tempo e custos do que se efetuadas manualmente (por exemplo: modelos digitais do terreno, cálculos de declividade e bacias de drenagem, sobreposiçåo de múltiplos conjuntos de mapas contendo poligonos complexos, etc.).

\footnotetext{
2DANGERMOND, 1. (1990). A Classification of Software Components Commonly Used in Geogruphic information Systame in: Introductory Readings in Geographic Information Systems. Pswquet. D. J.. Marble, DF, eds, p. 30-51. apud CALUURI, M.L., ROHM. S.A. (1994). Sixtcmas de informąues Geograficas. Universidade Federal de Viçosa - Imprensu Universitária, pa 5-34.
} 
A implantação de um SIG não é uma tarefa fäcil, principalmente, se levados em consideração os custos envolvidos com a aquisiçăo de dados e treinamento de pessoal. DE MAN ${ }^{3}$ (1988) apud LEIPNIK et al. (1993) identificou como fases de implementaçăo de um SIG: estudos de viabilidade, para dar apoio a decisão de implantação ou não do sisterna; seleçấo de software, hardware e periféricos; instalaçằ do sistema; treinamento; conversâo de dados; desenvolvinento de bancos de dados e por último, a geração dos primeiros produtos. Diante da variedade de soffware disponiveis no mercado, é imprescindivel que o possivel usuário tenha suas metas bem definidas, de forma a garantir a escolha ideal de um software de SIG para as análises desejadas.

Quando um SIG $\dot{\varepsilon}$ adquirido como parte de um projeto especifico. com objetivos limitados, normalmente a versatilidade e capacidade de geração de informaçồes do SIG não são suficientemente exploradas e o usuário acaba por nâo ter um bom retorno do investimento. Nesse sentido, tem-se sempre que ter em mente que as possibilidades de aplicaçồes de SIG em projetos de planejamento sâo bastante variadas, devendo ser exploradas ao máximo. E mais, é essencial que se entenda que o SIG é um meio, uma ferramenta, e não um fim. A determinação das metas a serem atingidas, às quais o SIG deverá dar suporte, precede a sua implantação. FERRARI (1996) comenta: "SIGs devem ser considerados como ferramentas que auxiliam a organizaçâo a cumprir sua missão fundamental e atingir suas metas estratégicas de curto e longo prazo."

Ao analisar o uso de Sistema de Informaçōes Geográficas, FERRARI (1997) classifica as atividades de uma organização em três niveis: operacional. gerencial e estratégico. A utilização de SIG no nivel operacional deve ter por objetivo reduzir os custos de operação de atividades que implicam em grandes esforços manuais, automatizando-as, como por exemplo: manutençâo do mapa base sob forma digital; uso do mapa digital no suporte ao projeto e execução de obras de engenharia;

\footnotetext{
${ }^{3}$ DE MAN, W.H,E (1988). Establishing a Gicographical Information System in Relation to lis Use: A process of Strategic Choices. Int. J. Geographic Information Systems, n 2, p. 245-261, anud L FIPNIK. M.R.: KFMP. K. K. LOAICIGA, H.A. (1993). Implementation of GiS tor Water Resouces Planning and Management. Journal of Water Resources Planning and Management, v, 119, n, 2, 18.4-205.
} 
manutenção do cadastro imobiliário: suporte a emissāo de guias e alvarás c gerenciamento de redes de infra-estrutura.

No nivel gerencial, o objetivo principal é servir de apois a melhores tomadas de decisões por parte da organização. Dessa forma, as administraçòes municipais devem ser beneficiadas por uma maior efieiência nas decisões de planejamento e gerenciamento urbano. Aqui o SIG é utilizado como ferramenta de análise espacial e locacional, para a modelagem e simulação de situações, apoiando aplicaçōes do tipo: fornecimento de subsidios á elaboração da política de uso e ocupação do solo; planejamento e gerenciamento de equipamento e serviços urhanos: locação de novos equipamentos, avaliaçăo do sistema de transporte coletivo ou de coleta de lixo; alocaçào de recursos públicos e monitoramento ambiental.

No nive] estratégico, as finalidades são dirigidas a estratégia comercial da administraçăo, como por exemplo: a melhoria da imagem da administraçăo perante outros órgãos públicos e perante à população, demonstrando maior eficiência nos serviços prestados. Os SIGs podom ser usados para dar suporte em todos os três niveis. Porém, como a natureza das atividades é diferente, também serào diferentes os beneficios oriundos da utilização de SIGs em cada um desses niveis de atividades (FERRARI. 1997).

Os SIGs também podem ser usados servindo diretamente à sociedade, ou seja, oferecendo melhores serviços á população, melhor qualidade de vida e participaç̧ెes da sociedade em decisões. O SIG é considerado como uma ferramenta de apoio. Um SIG nato tem a capacidade de resolver nada sozinho; nảo toma decisỏes e nem reduz custos. SIGs viabilizam projetos, facilitam o trabalho, fornecem suporte á decisðes.

Conclui-se que a sua aplicação na àrea de planejamento urbano é a mais variada possivel, podendo atuar no sistema de transportes, redes de distribuição de água e coleta de esgoto, uso e ocupaçảo do solo, cadastro imobiliário, e outros.

A tabela 3.1 compara os modelos de utilização de SIGs apresentados anteriormente e estabelece um relacionamento entre usos e beneficios. Quais são os beneficios que podem ser esperados do uso de SIGs em apoio as atividades do nivel 
operacional? Eficiência operacional: ganho em produtividade, redução de custos e qualidade na execuçào de tarefas. Quais são os benefícios que podem ser esperados do uso de SIGs em atividades do nivel gerencial? Eficácia administrativa: melhor planejamento e gerenciamento, melhores decisỏes de caráter tático e assim por diante.

Vale ressaltar que os beneficios apresentados na tabela a seguir são os beneficios imediatos. Exemplificando, o beneticio imediato do uso de SIGs no nivel operacional ć a eficiência operacional, ou seja, ganho em produtividade, reduçâo ou eliminaçån de custos e qualidade da execuçẩo de tarefas. Outros beneficios poderão surgir com o tempo, mas estes serão uma consequência do beneficio imediato. 
TABEL A 3.1 - Modelos de utilização de SIGs e seus benefícios imediatos.

\begin{tabular}{|c|c|c|}
\hline $\begin{array}{l}\text { Tipos de Uso } \\
\text { (suporte à...) }\end{array}$ & Beneficio Imediato & Caracterizaçāo dos Benefícios \\
\hline $\begin{array}{l}\text { Atividades do nivel } \\
\text { operacional }\end{array}$ & Eficiência operacional & $\begin{array}{l}\text { - Ganho em produtividade } \\
\text { - } \quad \text { Reduça de custos } \\
\text { - Qualidade da cxecução de tarefas }\end{array}$ \\
\hline $\begin{array}{l}\text { Atividades do nivel } \\
\text { gerencial }\end{array}$ & Eficácia administrativa & $\begin{array}{l}\text { - Melhor planejamento e } \\
\text { gerenciamento } \\
\text { - Melhores decisoes de caráter } \\
\text { tático (como na alocação de } \\
\text { recursos) }\end{array}$ \\
\hline $\begin{array}{l}\text { Atividades do nivel } \\
\text { estratégico }\end{array}$ & Avanço estratégico & $\begin{array}{l}\text { - Melhoria da imagem junto aos } \\
\text { clientes e parceiros } \\
\text { - Compartilhamento de custos } \\
\text { - Novas fontes de receita, aumento } \\
\text { de receita }\end{array}$ \\
\hline Projetos sociais & $\begin{array}{l}\text { Avanço social e } \\
\text { estratégico }\end{array}$ & $\begin{array}{l}\text { - Melhores serviços prestados à } \\
\text { população } \\
\text { - Participação da sociedade em } \\
\text { decisões } \\
\text { - Melhoria da imagem da } \\
\text { administração pública }\end{array}$ \\
\hline
\end{tabular}

Fonte: FERRARI (1997). 


\subsection{Os Sistemas de Informações Geográficas e a Engenharia de Transportes no Brasil}

Os SIGs vêm sendo utilizados de forma cada vez mais promissora, nas mais diferentes areas de aplicação, inclusive a Engenharia de Transportes. Dentre as diversas aplicaçōes em transportes podem ser citadas: projeto geométrico de vias, projeto de terraplenagem, moniloramento e controle de tráfego, oferta e demanda de transportes, prevenção de acidentes, otimização de rotas, monitoramento e controle de operaçôes rodoviárias, monitoramento de unidades móveis, dentre outras (VIVLANI et al, 1994; SILVA et al., 1994).

Para traçar una linha evolutiva, alguns trabalhos foram selecionados e analisados nos principais congressos, simpósios, seminários e revistas que abordam a questảo dos transportes no Brasil. A ANPET - Associação Nacional de Pesquisa e Ensino em Transportes, principalmente através de seus congressos anuais, tem contribuido bastante para a divulgação do assumto no país.

Um dos primeiros trabalhos em SIG-T publicados no Brasil foi, segundo SILVA (1995), o de KAGAN et al. (1992). O objetivo principal deste trabalho era discutir a potencialidade de um SIG no planejamento de transportes.

NOVAES \& ROSSETO (1993) apresentaram um método de dimensionamento e localização de depósitos de distribuição numa determinada regiào. Jả MARTINS \& IVERSSON (1993) mostraram o processo de conversão das bases cartográficas existentes para o formato digital, complementadas por informaçōes alfa-rnuméricas de diversas fontes, formando uma importante base de dados.

PIMENTEL \& SALGADO (1994) apresentaram uma visão geral sobre Sistema de Informaçðes Geográficas, evolução computacional, ponto de vista dos usuários finais e um exemplo de aplicação na Engenharia de Tráfego. FERREIRA et al. (1994) desenvolveram uma metodologia para o planejamento da rede de transportes coletivos urbanos por ònibus, por meio da fotointerpretação de imagens de satélite e de modelos matemáticos para obter rotas para o transporte público. 
Outros dois trabalhos procuraram tratar do problema da adaptaçâo de SIG para gerenciamento e operaça de sistema de transpone coletivo (NASSI et al.. 1994: SIQUEIRA \& CASSUNDE, 1994).

VIVIANI et al. (1994) analisaram as potencialidades dos SIGs e discutiram a viabilidade do uso desses sistemas no desenvolvimento de um processo de gerenciamento de vias não pavimentadas, especificamente de estradas municipais. SILVA et al. (1994) destacaram a importância da utilização de SIGs no planejamento e reestruturaçảo de sistemas de transporte público urbano. ROSSETO \& CUNHA (1994) enfocaram a utilização de um soffware de SIG, denominado, GisPlus, na roteirizaçåo de veículos para a distribuição de carga. ALENCAR \& AQUINO (1994) apresentaram um sistema denominado SIGTRANS, desenvolvido a partir de um software do tipo CAD, de um hanco de dados e de um sistema de controle para o planejamento de rotas de transporte coletivo. DAVIS \& FONSECA (1994) apresentaram o Geoprocessamento em Belo Horizonte em sua perspectiva histórica, evoluçầo, objetivos e disseminação. Algumas das aplicações jâ realizadas foram mostradas, com destaque para o sistema de transporte coletivo.

O trabalho de ANDRADE \& MENDES (1995) fez uma abordagem ao sistema informatizado de planejamento de transportes para o plano multimodal de transportes do Estado de Minas Gerais. SiLVA et al. (1995) apresentaram uma aplicação de um SIG na avaliação dos impactos sobre os sistemas de transporte público e do crescimento urbano e desorganizado ocorrido na cidade de Araraquara SP. Os autores concluiram que os SIGs podem representar um ferramenta de grande valia para planejamento de cidades em paises em desenvolvimento que sofrem um processo intenso de urbanização e ao desenvolvimento dos diversos setores (econônico. social e politico) que as compõe. SILVA \& KAWAMOTO (1995) utilizaram um software de SIG, denominado TransCAD. para avaliar o desempenho de um sistema de transporte público na cídade de São José do Rio Pardo - SP, caracterizada como uma cidade de pequeno porte.

Uma importante contribuiçào à comunidade cientifica encontra-se presente no trahalho de SILVA (1995) que apresentou uma visão geral do uso de Sistema de Informações Gcográficas em atividades ligadas à Engenharia de Transportes no 
Brasil (SIG-T). O autor fez uma retrospectiva dos principais trabalhos sobre o tema no país, mostrando a evolução, desde as primeiras sugestỏes de uso até os projetos $\mathrm{em}$ andamento. culminando com as perspectivas para of futuro.

ZUPPO et al. (1996) descreveram a criação do sistema geográfico de transporte e trânsito, com especial destaque para a modelagem de dados, formaçăo da base de dados e aplicações. O trabalho de NASSI et al. (1996) visou a elaboração e desenvolvimento de um programa de consulta de itinerários, tendo sido executado um programa especifico para este fim. Alguns aspectos de análise espacial foram observados nos trabalhos de DANTAS et al. (1996); TACO et al., (1996); BARTOLLI et al., (1996). Já LOUREIRO \& RALSTON (1996) utilizaram o SIG como plataforma para modelos de análise de redes de transporte.

DAVIS (1997) apresentou o algoritmo do caminho mínimo usado para aplicaçōes em problemas de roteamento urbano, OLIVEIRA \& RIBEIRO (1997) propuseram um sistema que utiliza $\mathrm{SIG}-\mathrm{T}$ na produçào de planos de sincronismo empregando o TRANSYT. PINTO \& LINDAU (1997) relataram a experiência de montar um cadastro de linhas de ỏnibus intermunicipais usando um SIG. MARQUES \& SILVA (1997) propuseram a implantaçào de um sistema de consulta por telefone para usuários de transporte coletivo, oferecendo informaçỏes desde a localização dos pontos de parada de ônibus até a determinação de rotas ótimas, via ônibus, entre dois pontos quaisquer informados pelos passageiros.

Após muitos anos de pesquisas e inovaçŏes tecnológicas, os SIGs têm apresentado um acentundo aumento de sua taxa de adoção. pois representam uma tecnologia que oferece ferramental operacional, que auxilia e agiliza os procedimentos de planejamento, gerenciamento e de tomadas de decisào. Além disso, constituem uma tecnologia computacional relativamente nova. que está revolucionando a forma com que os complexos problemas de transportes podem ser analisados. Os estudos realizados até o momento nào deixam dúvidas que esses programas podem ser ferramentas extremamente úteis no planejamento de transportes. 


\subsection{O software TransCAD}

A revisão na literatura foi realizada com o objetivo de guiar a escolha de um soffware de SIG, a ser utilizado neste trabalho. Os critérios utilizados para esta escolha foram baseados nas seguintes caracteristicas:

- Ampla aplicação em transportes no Brasil e no mundo;

- Simples, não exigindo equipamentos muito sofisticados e de preferência apropriado para se trabalhar na plataforma PC;

- Disponibilidade;

- Versátil na integração com outros software;

- E, de preterenncia, que já estivesse sendo utilizado em trabalhos envolvendo planejamento de transporte público.

Pautados nestas consideraçōes, optou-se pela escolha do software TransC $A D$ for Windows, desenvolvido pela Caliper Corporation. Segundo o fabricante, o software utilizado, ao reunir os recursos de um SIG e várias ferramentas de planejamento de transporte, pode fornecer aos usuários amplo acesso á base de dados geográficos e de transporte, com a possibilidade de combinar estes elementos de diferentes maneiras (SILVA et al., 1994). Estas caracteristicas o tornam uma ótima opção para trabalhar com estudos relacionados ao plancjamento de transportes, como por exemplo na reestruturação de sistemas de transporte público urbano. SILVA et a. (1994) utilizaram o. TransCAD, como ferramenta, para realizar estudos no planejamento e reestruturação de sistemas de transporte público urbano. Conchuiram que esse programa pode ser uma ferramenta extremamente valiosa na reestruturaçâo de sistemas existentes, bem como no planejamento de novos sistemas.

O soffware TransCAD, atualmente em sua terceira versào (para Windows), foi um dos primeiros pacotes de SIG-T desenvolvidos especialmente para serem utilizados como uma "ferramenta de planejamento, gerència, operação e análise de sistemas de transporte, incorporando, além das funçóes básicas de um SIG, rotinas especificas para soluçâo de problemas de logistica, pesquisa operacional e de 
transporte em geral. Fstas rotinas permitem aos usuários aplicar não só funções básicas de análise de redes, tais como: determinar a rota de menor impedância entre nós e distribuir viagens entre zonas, como também resolver problemas convencionais de roteamento e escalonamento de veiculos, localização de instalaçōes, alocaçăo de recursos em redes, alocąào de tráfego, dentre outros" (L,OUREIRO \& RALSTON, 1996).

Outra grande vantagem do TransC.AD, essencial para viabilizar a construção de interfaces de SIG com modelos externos, especialmente quando se descja automatizar ou simplificar tarefas e facilitar a operação ao usuário, refere-se à sua linguagem macro de programação, que permite aos usuários desenvolverem suas próprias rotinas, em qualquer outra linguagem, integrando-as à caixa de ferramentas do pacote, aumentando consideravelmente seu potencial analitico. A versāo 3.0 do TransCAD abrange um kit de desenvolvimento, denominado GISDK (Geographic Information System Developer's Nit), que inclui uma poderosa linguagem macro de programação - Caliper Script. Esta permite a construçăo de interfaces personalizadas para o TransCAD, tornando-o adequado a diferentes aplicaçôes. Ela também possibilita a construção de rotinas para troca de dados com programas externos (OLIVEIRA. 1997; LOUREIRO \& RALSTON, 1996). 


\section{METODOLOGIA}

Neste capitulo descreve-se detalhadamente a metodologia empregada neste trabalho para a montagem do sistema de consulta de itinerários, desde o aprendizado do software até o processamento dos dados.

\subsection{Introdução}

A metodologia foi elaborada tendo como ponto de apoio e fundamentação o Sistema de Informaçōes Geográficas (SIG), uma vez que este tem se mostrado uma ferramenta poderosa, que auxilia e agiliza os procedimentos de planejamento, gerenciamento e de tomadas de decisão.

Um SIG armazena, analisa e manipula dados geográficos, ou seja. dados que representam objetos e fenômenos em que a localização geográfica é uma caracteristica inerente à informação e indispensável para analisá-la (CẢMARA et al., 1996). 0 software escolhido foi o TransCAD, que segue o concento de SIG descrito anteriormente, desenvolvido especialmente para aplicaçōes em transportes, cujo uso dependerá dos estudos a serem realizados.

Inicialmente será feita uma apresentaçẵo do funcionamento do sistema de consulta de itinerários, desde a localização da origem e destino informados pelo passageiro até a descriçầo do itinerário completo para informações por telefone. A 
seguir, será feita uma descrição das etanas da metodologia empregada, e por último, um sumário das atividades desenvolvidas.

\subsection{Funcionamento do Atendimento a Consultas}

O processamento do atendimento a consultas de itinerários será feito de acordo com o fluxograma mostrado na figura 4.1 , tendo sido baseado no trabalho desenvolvido por ZUPPO et al. (1996) em Belo Horizonte. Cada etapa será descrita a seguir.

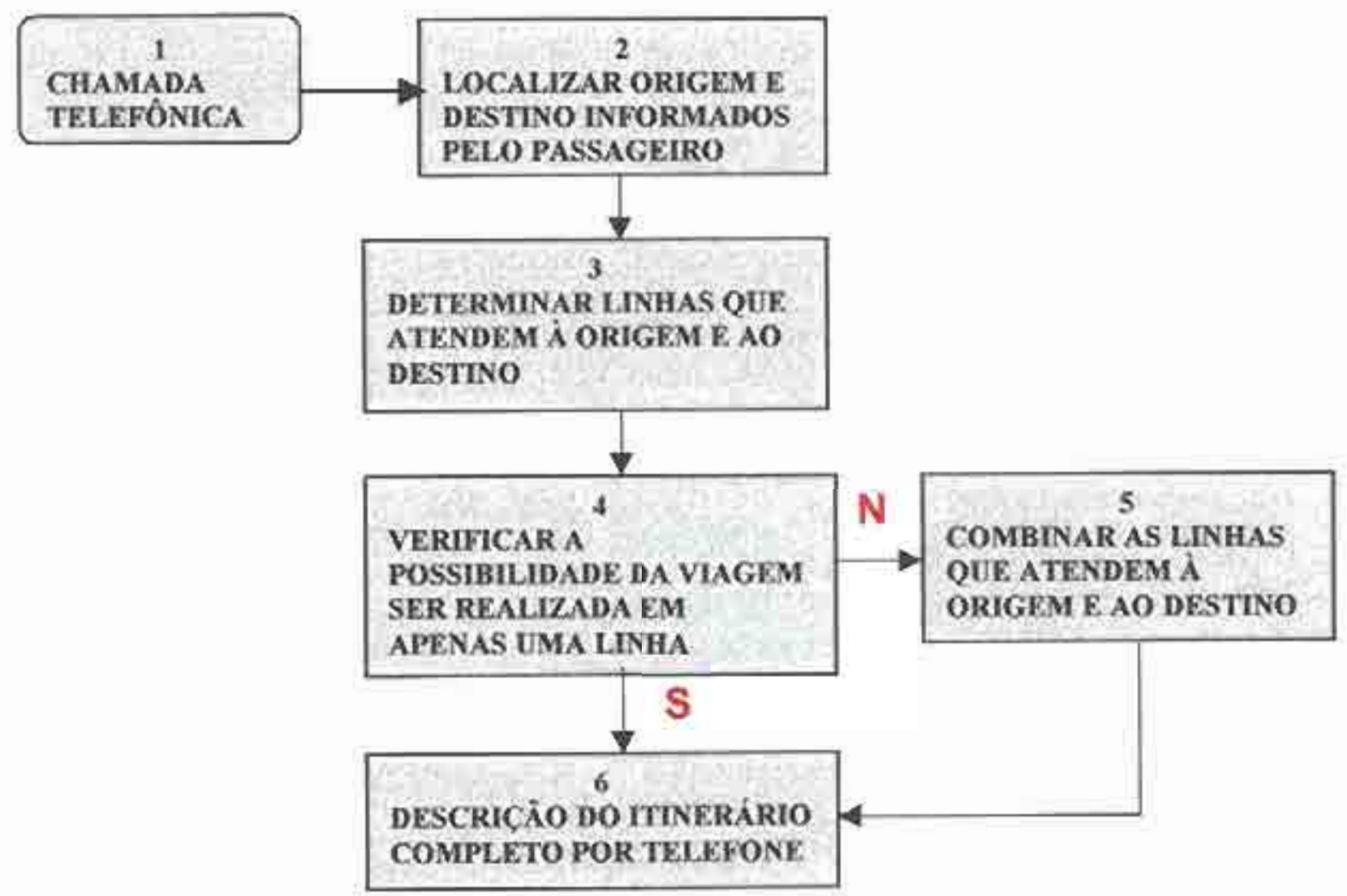

FIGURA 4.1 - Fluxograma de processamento de consultas.

Fonte: Adaptado de ZUPPO et al. (1996). 


\section{Registro da Chamada Telefônica}

Inicia-se com a conversaçăo telefồnica entre o passageiro e o operador do sistema de consulta de itinerários.

\section{Localizar Origem e Destino Informados pelo Passageiro}

Parte-se do principio que o passageiro poderá informar a sua localizaçào através das seguintes maneiras:

- Endereço completo (logradouro-número-bairro);

- Cruzamento de vias;

- Trecho (logradouro entre logradouros):

- Ponto de referência (escola, shopping center, hospital, agência bancária, etc.).

Os pontos de referència abrangerão a localização geográfica de diversos marcos da cidade, ou seja, elementos de reconhecimento simples e imediato. A princípio serão adotadas as seguintes categorias:

- Escola (pública, particular, universidade);

- Hospital (centro de saúde, pronto socorro);

- Unidade da policia (militar, civil, federal);

- Agência de atendimento (postos de serviços integrados urbanos, correios. concessionárias, prefeitura):

- Cartório;

- Terminal de transpories (aeroporto, rodoviária, ferroviária);

- Shopping center (loja de departamentos);

- Mercado (central, distrital, supermercado); 
- Atração turistica ou cultural (bar, restaurante, casa noturna, tçatro, cinema, museu, biblioteca);

- Templo:

- Cemitério;

- Clube recreativo:

- Area de lazer (zoológico, parque, lagoa, mirante, horto florestal);

- Esporte (cstádio, ginásio, praça de esportes, jóquei);

- Hospedagem (hotel, motel, apart-hotel);

- Prédio público (repartição municipal/estadual/federal, estatal):

- Agẻncia bancária.

\section{Determinar Linhas que Atendem à Origem e ao Destino}

Tendo a localização geografica da origem e do destino do passageiro, o sistema localizará os pontos de parada mais próximos do emharque e desembarque com base em critérios geográficos. Para isto é necessário definir o raio da pesquisa, ou seja. considerar os pontos de parada situados a menos de $x$ metros da origem e do destino.

\section{Verificar a Possibilidade da Viagem ser Realizada em uma Linha}

Inicialmente será investigada a possibilidade da viagem ser realizada em uma linha. Caso isto aconteça, o processamento prosseguirá para o passo 6: caso contrário. prosseguirá para o passo 5 . 


\section{Combinar as Linhas que Atendem à Origem e ao Destino}

Caso nào seja possivel realizar a viagem em apenas uma linha, serả necessário fazer uma combinaçåo entre as linhas que servem à origem $e$ an destino. $O$ sistema determinará o ponto de embarque em cada linha, o número de paradas durante o percurso e o ponto de desembarque em cada linha.

\section{Descrição do Itinerário Completo por Telefone}

O resultado final da consulta será apresentado para o operador e deverá ser lido e explicado ao passageiro. por telefone. sobre como proceder para realizar a viagem. Esta saída poderá conter informações sobre o custo total generalizado de viagem entre cada origem e destino, a tarifa paga, o número de transferências, o tempo esperando para embarcar nos ônibus, as caracteristicas do menor caminho para cada atributo de rede $\mathrm{e}$ instruçőes para realizar a viagem.

Uma aplicação prática do sistema, aqui descrito, será mostrada no próximo capitulo, assim como alguns comentários sobre o mesmo.

\subsection{Etapas da Metodologia Empregada}

Todo potencial das aplicaçôes é precedido de várias etapas consideradas volumosas e trabalhosas, principalmente pelo processo de aquisição do know-how e aprendizado do soffware. Para cumprir estas etapas, foram desenvolvidos os seguintes procedimentos, apresentados a seguir: 


\subsubsection{Aprendizado do Software}

Nesta etapa buscou-se uma familiarizaçào com o programa, estudando suas potencialidades e limitaçōes através de um pacote de auto-instruçẫo desenvolvido por SILVA \& WAERDEN (1997) Este tutorial consiste de 10 capitulos (figura 4.2) Os primeiros três capitulos abordam a criação e administração de diferentes tipos de bases de dados (pontos, linhas e áreas) Trabalhando com estes dados tem-se o primeiro contato com algumas ferramentas básicas de um SIG, como mudança de estilos de mapa, mudanças de escala, legenda e criação de arquivos geográficos (para o armazenamento de locaçôes, formas e atributos). Além disso, começa-se a perceber a diferença entre arquivos geograficos e mapas, como trabalhar com camadas (layers), modificar bases de dados, exibir e ocultar camadas (SILVA et al., 1997)

A segunda parte, dividida em cinco capitulos, apresenta ferramentas mais sofisticadas de SIG e sugere algumas análises com essas ferramentas. No capitulo 4 são mostrados diferentes modos para se criar um mapa temático. Em seguida, no capitulo 5 , sảo apresentadas diferentes bases de dados associadas a um mapa. No capitulo 6 são descritos diferentes métodos de seleção de dados (seleção por pontos, círculos, forma, condição) e como exibir, ocultar e desfazer seleçōes. A análise espacial é abordada no capitulo 7, onde tem-se noção de como agregar informações espaciais A confeção de mapas é mencionada no capitulo 8 . Devido a grande capacidade dos mapas de apresentar informaçôes, são mostradas maneiras de se alterar os estilos dos mapas, como caracterizar objetos no espaço (manual e automaticamente), como editar legendas e como adicionar desenhos à mão livre a um mapa (SILVA et al., 1997).

Os dois últimos capitulos apresentam ferramentas especificas que são muito usadas em planejamento de transportes. No capitulo 9 são mostradas operaçōes bàsicas no tratamento de matrizes, como criaçào, edição e apresentação de resultados em mapas. Finalmente, o último capitulo trata de análise de redes. Numa base de dados de linhas, aprende-se a criar uma rede de transportes, onde é possivel fazer análises, por exemplo. de menor caminho (SILVA et al., 1997). 


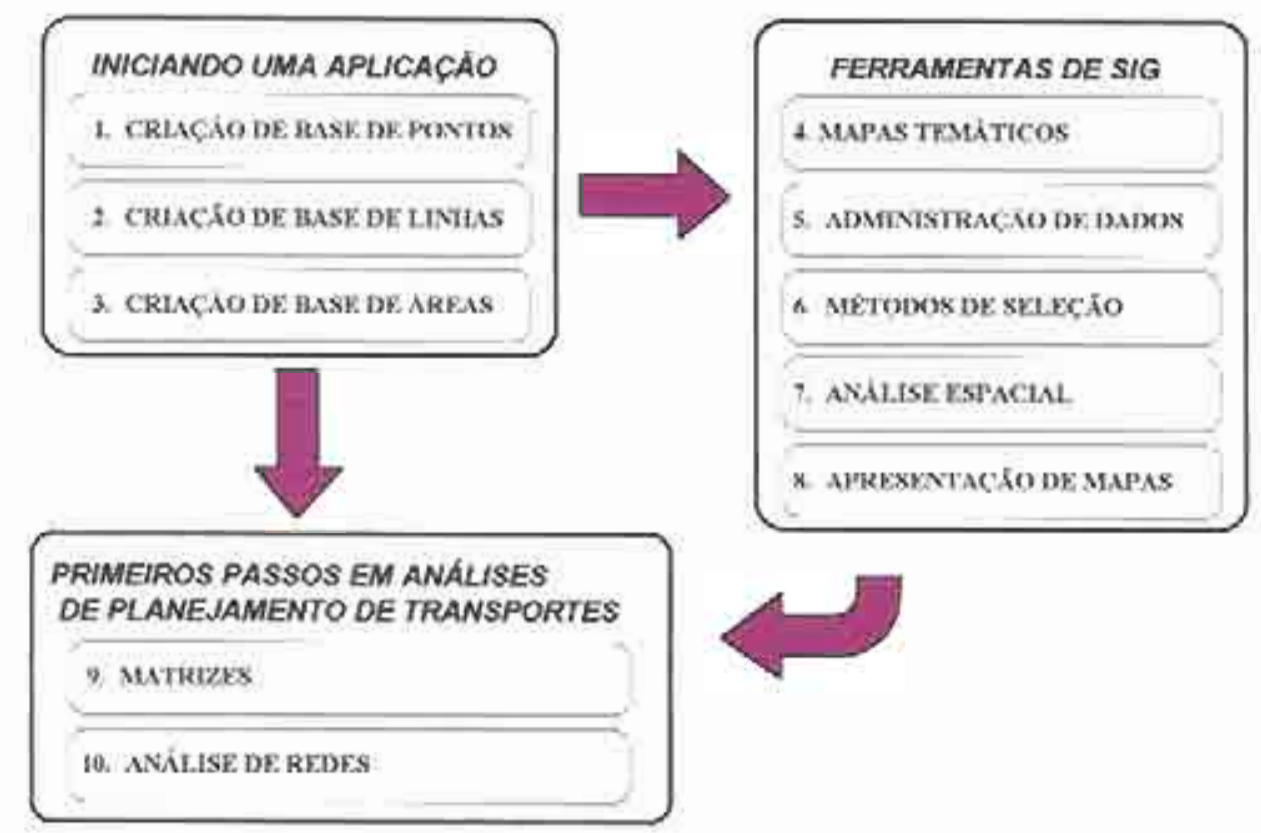

FIGURA 4.2 - Descriçăo dos capitulos do tutorial para o software TransCAD 3.0.

Fonte: SILVA et al. (1997)

\subsubsection{Coleta de Dados}

Os dados sobre a área de estudo foram coletados de acordo com as exigências do programa escolhido e as informaç̃es disponiveis. O programa exige uma gama muito grande de informaçōes, as quais podem ser classificadas, dependendo do formato em que são adquiridas e trabalhadas no SiG, em:

- Dados geográficos: são aqueles essencialmente espaciais. São eles: sistema viário, itinerários, pontos de parada, etc

- Atributos constituem dados de caráter quantitativo e qualitativo e que podem estar associados a um objeto espacial. O banco de dados alfa-numérico 
correspondente às vias da cidade pode conter algumas informaçōes fundamentais para o planejamento de transportes, tais como: tipo de pavimentação, declividade, largura da via, existência de estacionamentos na via, obstáculos, etc, (SILVA et al, 1994) No caso do sistema de transporte coletivo, correspondem ás tarifas, horarios disponiveis, frequência do serviço, caracteristicas dos pontos de parada de ỏnibus, etc

\section{a) Coleta de dados geográficos}

As informaçōes relativas ao sistema viărio foram obtidas em planta da prefeitura, em escala 1:10.000, com base em levantamento aerofotogramétrico de 1988 e restituição $\mathrm{em}$ 1989. Os itinerários das linhas de ônibus foram fornecidos gentilmente pela empresa Renascença, que opera o sistema na cidade de Sảo Carlos. Algumas informaçòes, como a localizaçăo dos pontos de parada de ônibus, tiveram que ser levantadas em campo. uma vez que não existia um mapa com a localização dos mesmos, nem mesmo ná empresa operadora. Foram percorridos, em um veiculo particular, aproximadamente 450 $\mathrm{km}$ do sistema viário e levantados todos os pontos de parada do sistema de transporte coletivo

A principal dificuldade encontrada foi a inexistência de qualquer tipo de identificação de pontos de ônibus nas áreas mais periféricas da cidade. Isto acarretou um aumento no tempo de coleta de dados, pois era necessârio pedir informaçð̃es a moradores. Vale ressaltar que seria desejável que a cidade adotasse um padrão de ponto de parada e que o mesmo se estendesse as regiỏes periféricas, nåo se limitando o tratamento apenas aos pontos localizados na região central. 


\section{b) Coleta de dados de atributos näo espaciais}

Assim como os dados geográficos, os nomes dos logradouros foram obtidos através de plantas da cidade de Sào Carlos, também na escala de 1:10000. Jả os dados referentes ao sistema de transporte coletivo por ònibus foram também obtidos através da empresa operadora.

\subsubsection{Hardware Usado}

Os equipamentos disponiveis para o perfeito desempenho das funçōes de digitalização dos dados, processamento de dados e apresentação das informações foram, respectivamente

- Mesa digitalizadora $12,0 \times 12,0$ polegadas;

- CPI: pentium $200 \mathrm{MHZ}, 128 \mathrm{MB}$ de memória RAM (não é necessária esta capacidade, embora estivesse disponivel) e um disco rigido de 2 GB com o sistema operacional Windows 95 :

- Versão acadêmica do programa TransCAD.

- Impressora jato de tinta colorida, série 600 da HP.

\subsubsection{Entrada de Dados}

Após a coleta de dados, a modelagem do problema começou. A primeira etapa foi a digitalização da base geográfica relacionada ao sistema viário (figura 4.3) No caso deste projeto, esta etapa foi favorecida devido à existência do mapa da cidade em formato digital, digitalizado num projeto anterior com auxilio de uma mesa digitalizadora, utilizando recursos do software TransCAD (SILVA et al., 1996). O passo seguinte foi a nomeaçăo dos logradouros, tendo sido utilizado como base um mapa em papel da cidade de São Carlos. 


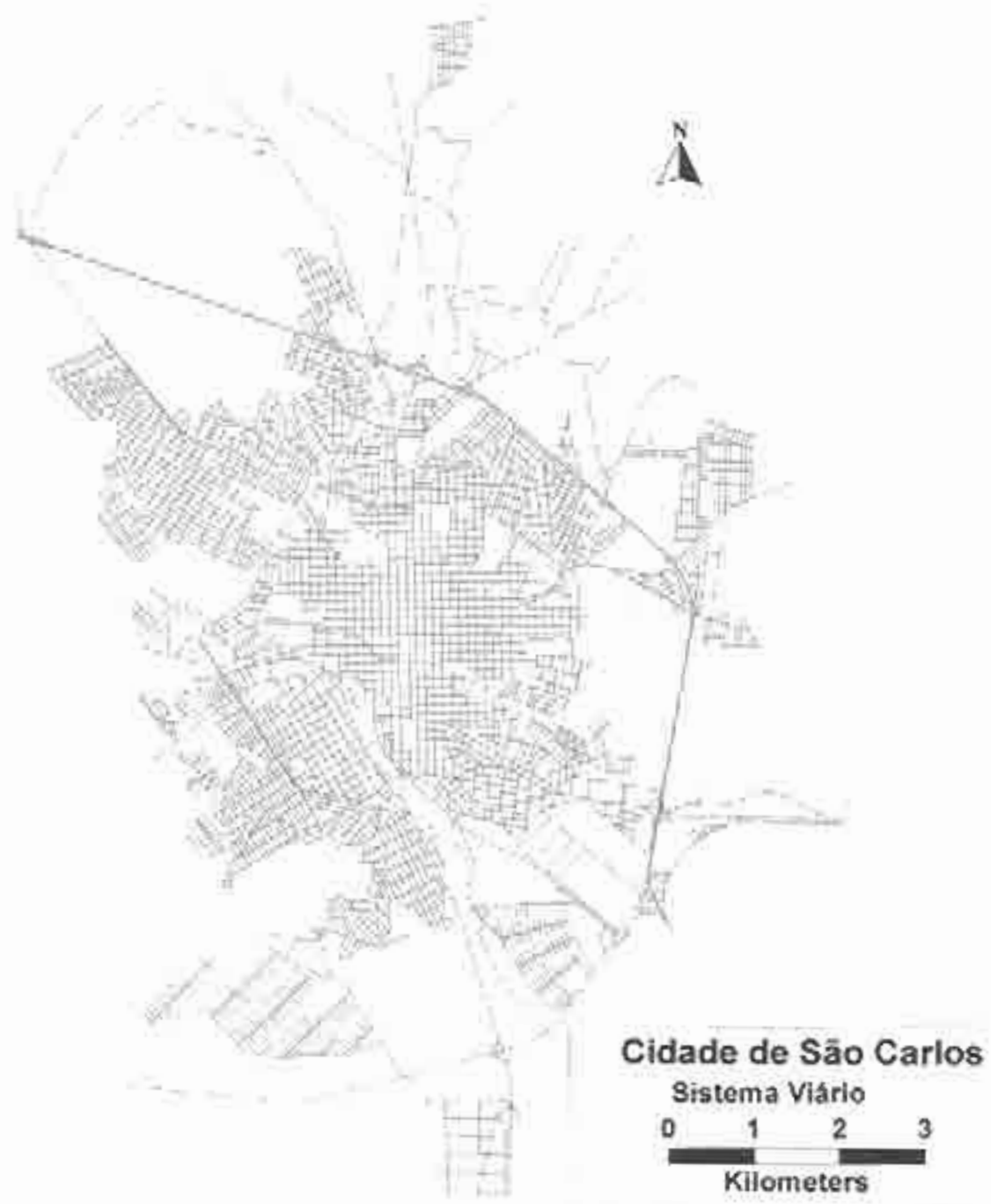

FIGURA 4.3 - Imagem vetorial do sistema viário digitalizado.

Para screm realizadas as análises desejadas, foi necessária a criação de uma rede de transporte, utilizando-se recursos disponiveis no sofiware. Esta rede, que conta atualmente com 4.550 nós e 12.838 arcos, está disponivel na base de dados do software TransCAD. Com este tipo de rede muitos problemas de transporte podem ser resolvidos, 
tais como: identificação de caminhos mínimos, roteirização de veículos, localizaçăo de instalaçôes, etc. (SII.VA \& WAERDFN, 1997).

A seguir, foram introduzidos novos niveis de informaçoes (outras camadas), a saber, a criaçấo de itinerários de linhas de onibus com seus respectivos pontos de parada, tendo como base o sistema viário. Esta etapa do trabalho exigiu um tempo considerável, uma vez que, como já foi mencionado. não existia um mapa com a localização dos pontos de parada, tendo sido necessário fazer um levantamento de campo (figura 4.4).

Em suma. os seguintes mapas foram digitalizados seguindo os procedimentos apresentados na tabela 4.1 .

TABEL A 4.1 - Mapas digitalizados requeridos neste projeto.

\begin{tabular}{|c|c|c|}
\hline Informaçōes & Objeto digitalizado & Formato digitalizado \\
\hline Sistema viário & ruas, avenidas, estradas, etc. & linhas \\
\hline $\begin{array}{c}\text { Sistema de Transporte } \\
\text { Coletivo }\end{array}$ & linhas e pontos de ônibus & $\begin{array}{c}\text { linhas e pontos } \\
\text { respectivamente }\end{array}$ \\
\hline
\end{tabular}




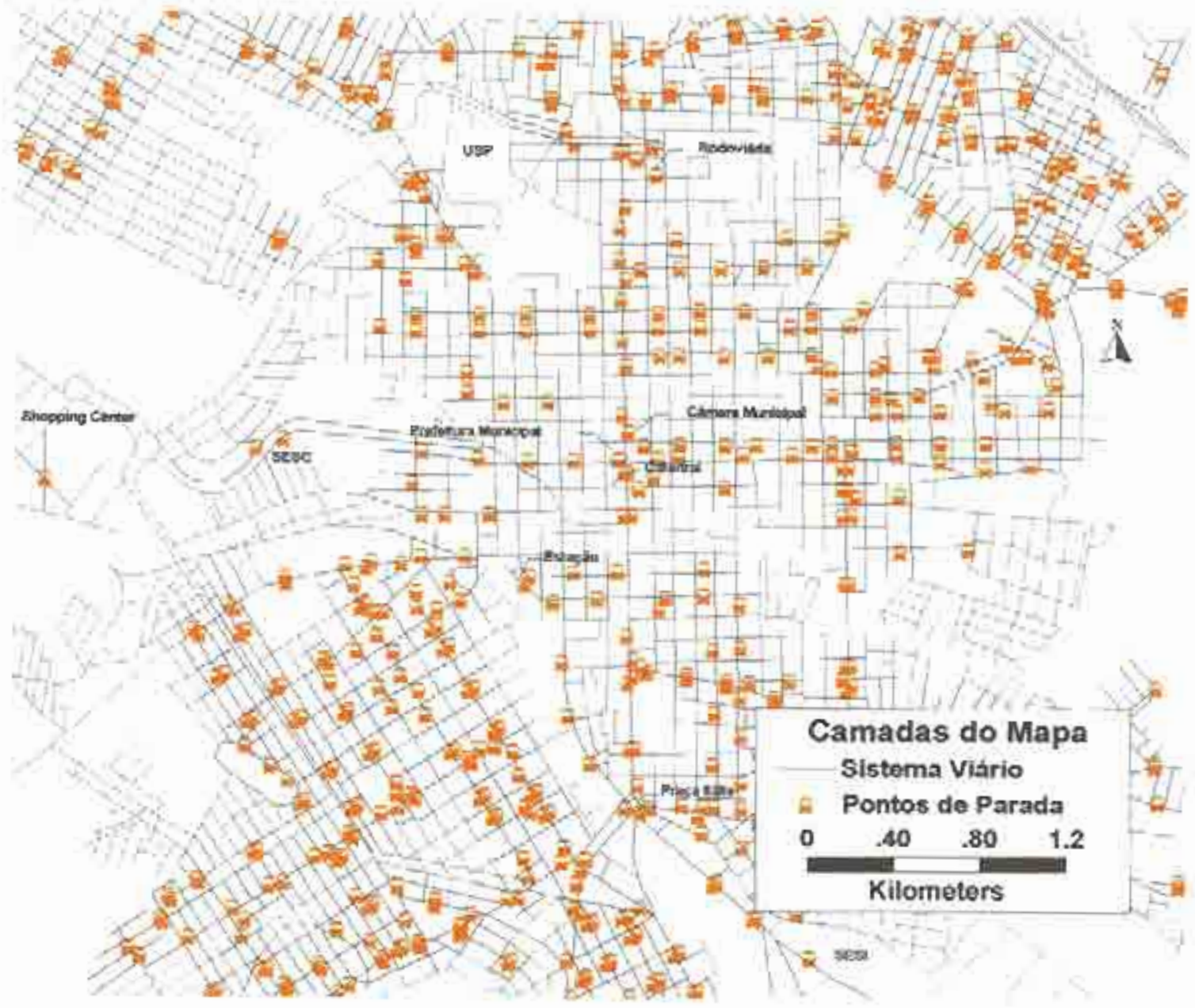

FJGURA 4.4 - Detalhe de um mapa de localização dos pontos de onibus da cidade de

$$
\text { São Carlos - SP. }
$$

\subsubsection{Processamento de Dados}

Uma vez introduzidos os dados, teve inicio a fase de processamento. Os recursos do software passaram a ser explorados, com a finalidade de permitir as análises desejadas. As rotinas utilizadas foram as seguintes: 


\section{a) Combinação de endereços}

$O$ sofrware dispỏe de ferramentas que permitem questionar sobre a localizaçăo geográfica de endereços e pontos de referência, armazenando as respostas em um conjunto de seleçōes e mostrando-as em destaque através de mapas (figura 4.5) e em um banco de dados (figura 4.6) (CALIPER, 1996b). Estas ferramentas sao capazes de responder a questōes como:

- Endereço completo (logradouro, número);

- Cruzamentos de vias;

- A localização de um ponto de referència (escola, shopping center. hospital. agencia bancária);

- Interseção mais próximas de cada ponto de ônibus.

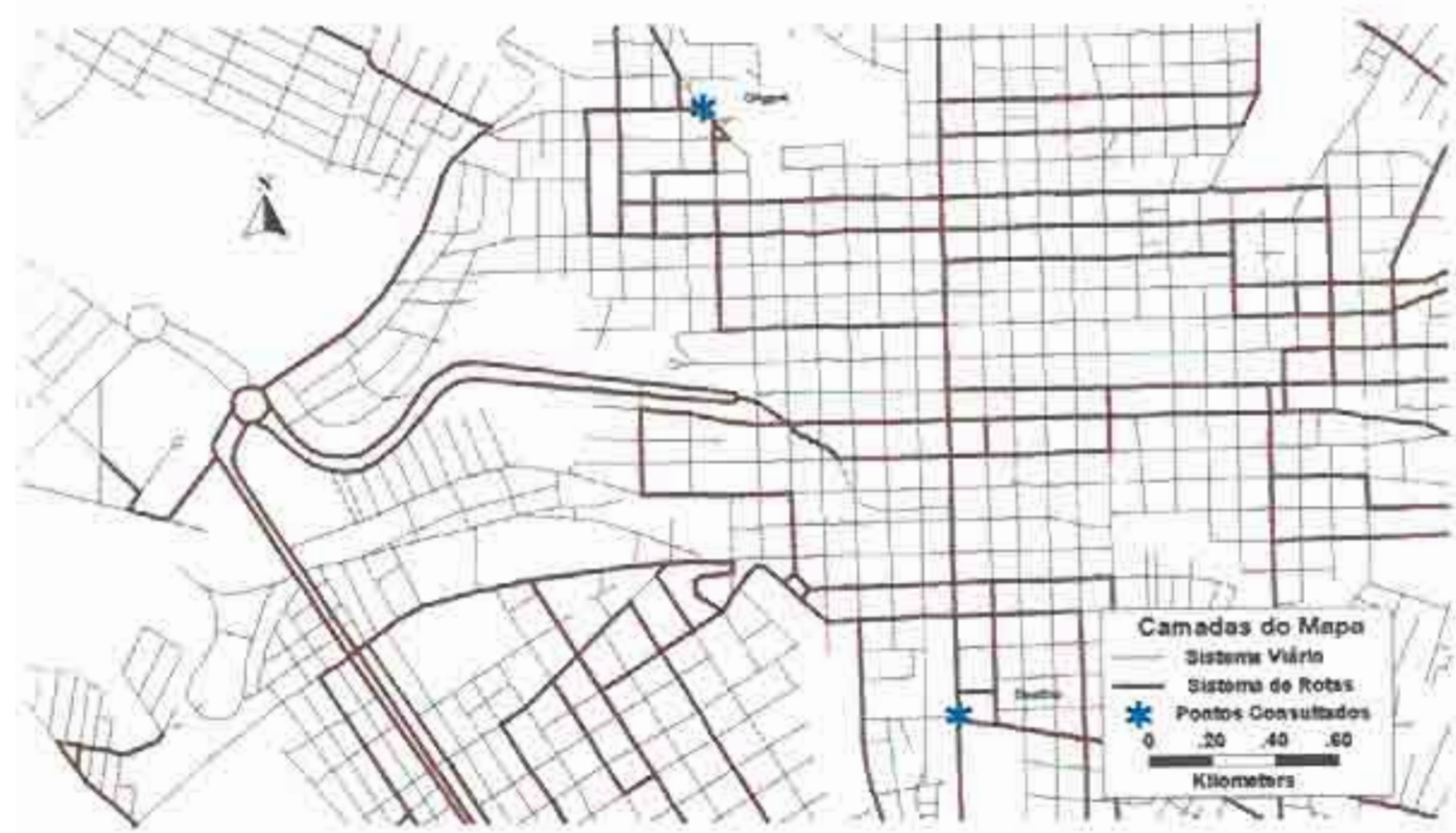

FIGURA 4.5 - Representação gráfica da localização da origem e do destino informados pelo passageiro. 


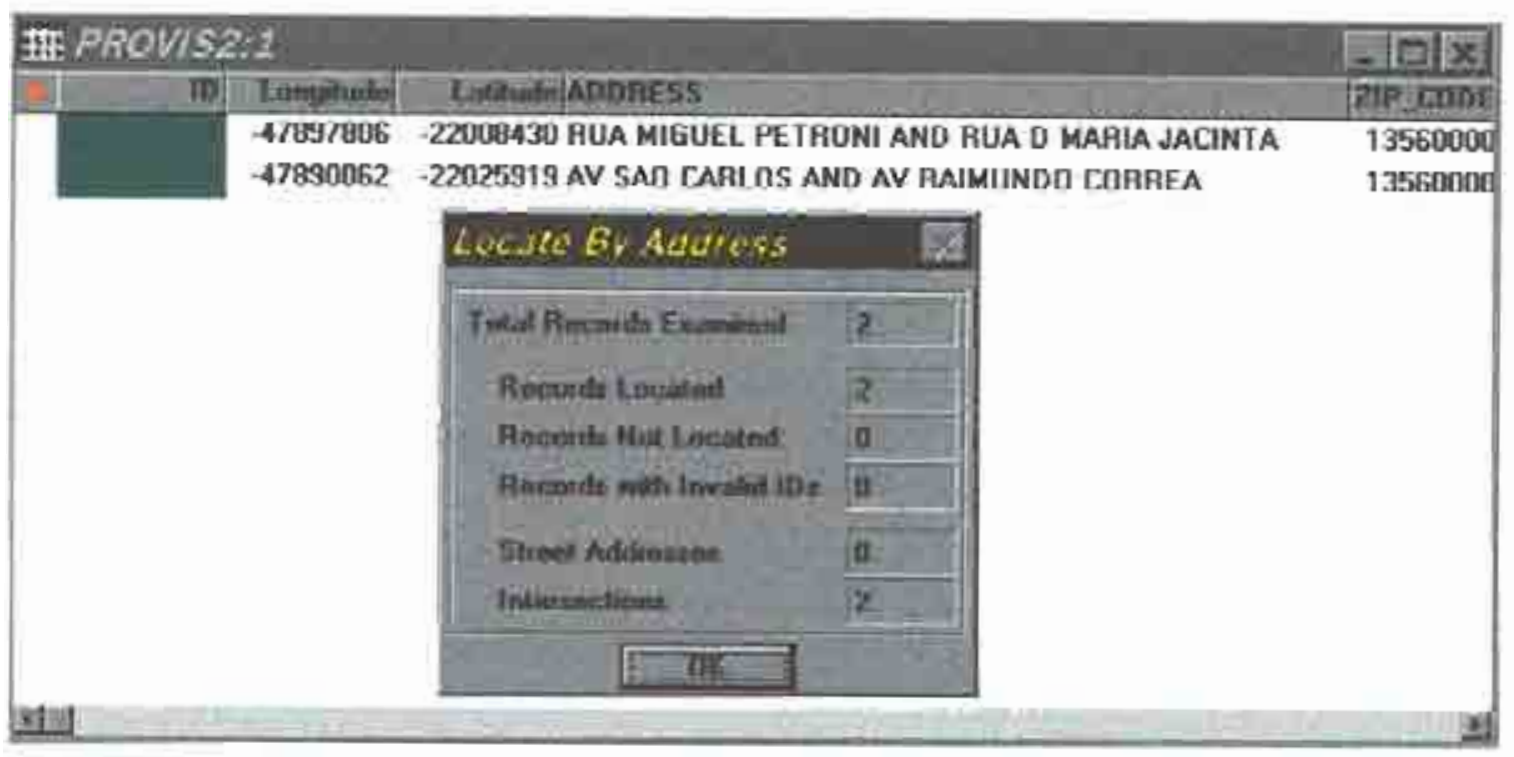

FIGURA 4.6 - Resposta gerada pelo programa sobre a localizaçâo geográfica de endereços.

\section{b) Sistema de rotas}

Rotas podem ser definidas como sendo um tipo especial de caracteristica geográfica, que representam os caminhos percorridos por vejculos, mereadorias e pessoas. Utilizando-se uma rotina especifica para se trabalhar com rotas, é possivel usar ferramentas para cditar, mostrar, perguntar e desenvolver análises geográficas sobre o sistema de rotas em questão (CALIPER, 1996b). Estas ferramentas, dependendo dos dados disponiveis, são capazes de responder entre outras, a quesţes como:

- Quais sảo as linhas de ónibus que vão do centro para o shopping center?

- Qual é a população atendida por uma ou mais linhas de ónibus?

- Qual o número de pontos de ónibus dentro de um raio de 400 metros a partir de uma escola, hospital, etc.?

- Qual é o melhot caminho ou caminho mais curto para ir de um lugar para outro?

- Quais såo os horários disponiveis?

- Qual é a frequência dos ônibus? 
TransC.AD armazena rotas em um sistema de rotas. Um sistema de rotas é uma camada do mapa que contém uma coleção de rotas, as quais podem ter informações associadas a elas, tais como: código da linha, nome da linha, headway, tipo de tarifa, capacidade, dentre outras.

Cada rota, em um sistema de rotas, é definida como sendo uma série de um ou mais elementos de uma camada de linhas. Por exemplo, uma rota de ônibus (figura 4.7) é definida por uma série de ruas sobre as quais o onibus viaja (CALIPER, 1996b).

Antes de se trabaihar com as ferramentas de edição de rotas, deve-se construir uma rede de transporte utilizando os links da camada, na qual o sistema de rotas é baseado. Trans $\mathrm{CAD}$ utiliza esta rede para determinar o caminho minimo entre pontos no mapa (CALIPER, 1996b).

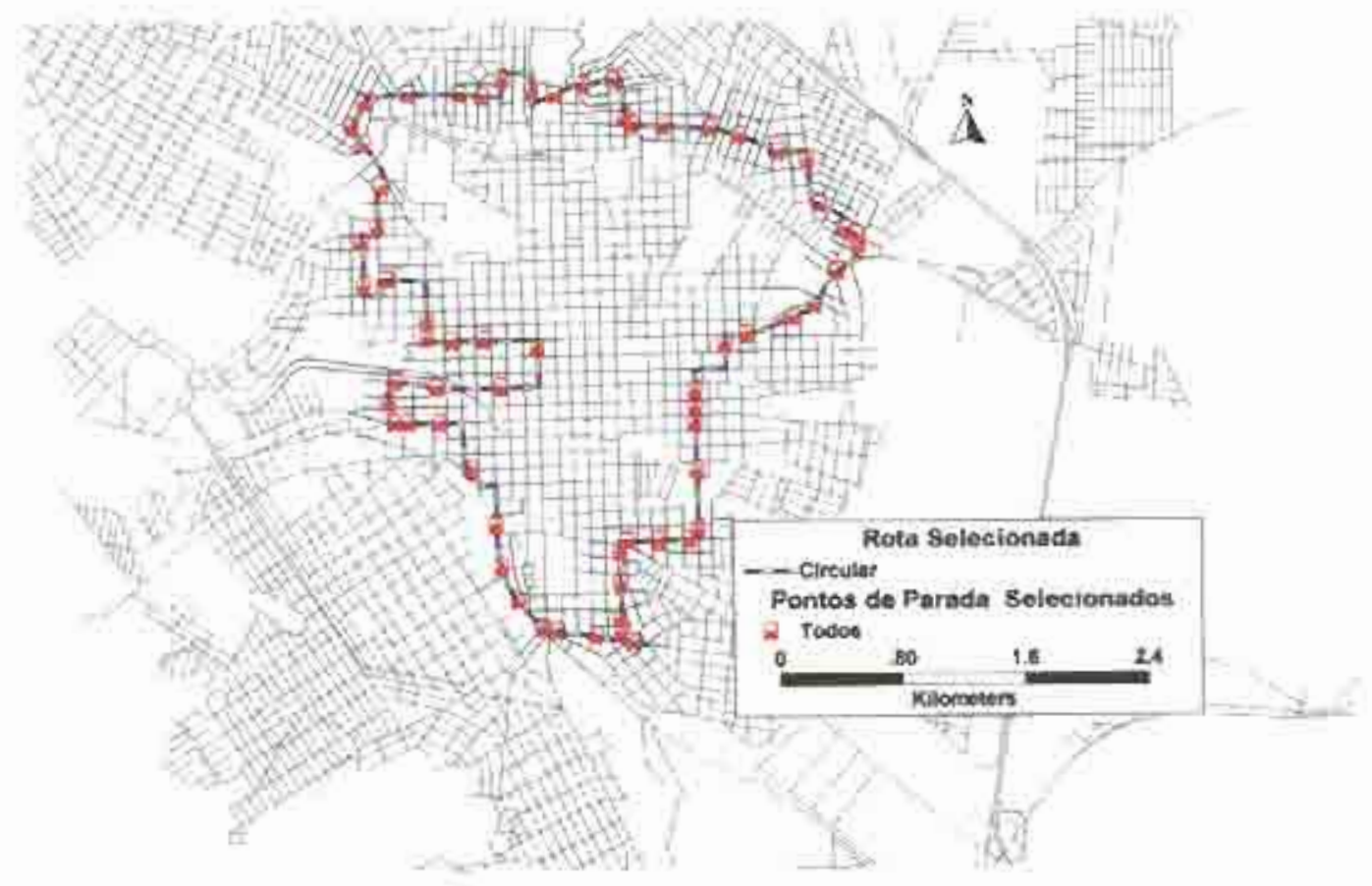


Quando várias rotas são digitalizadas no mapa pode ocorrer uma certa confusẩo na visualizaçấo da rede de transporte público. Para evitar que isto aconteça, existe uma opçào chamada tracking, que permite a sobreposiçảo de rotas, possibilitando assim uma melhor visualização da rede de transporte.

Para usar esta opção, deve-se escolher um campo na camada de rotas que identifica o caminho, no qual cada rota deve ser localizada. Cada vez que o mapa é desenhado, TransCAD encontra todas as rotas que tem o mesmo valor para o campo tracking, e desenha-as agrupadas como mostrado na figura 4.8 (CALIPER, 1996b). Neste caso, todas as rotas apresentam a mesma tarifa c por isso são desenhadas com uma mesma cor.

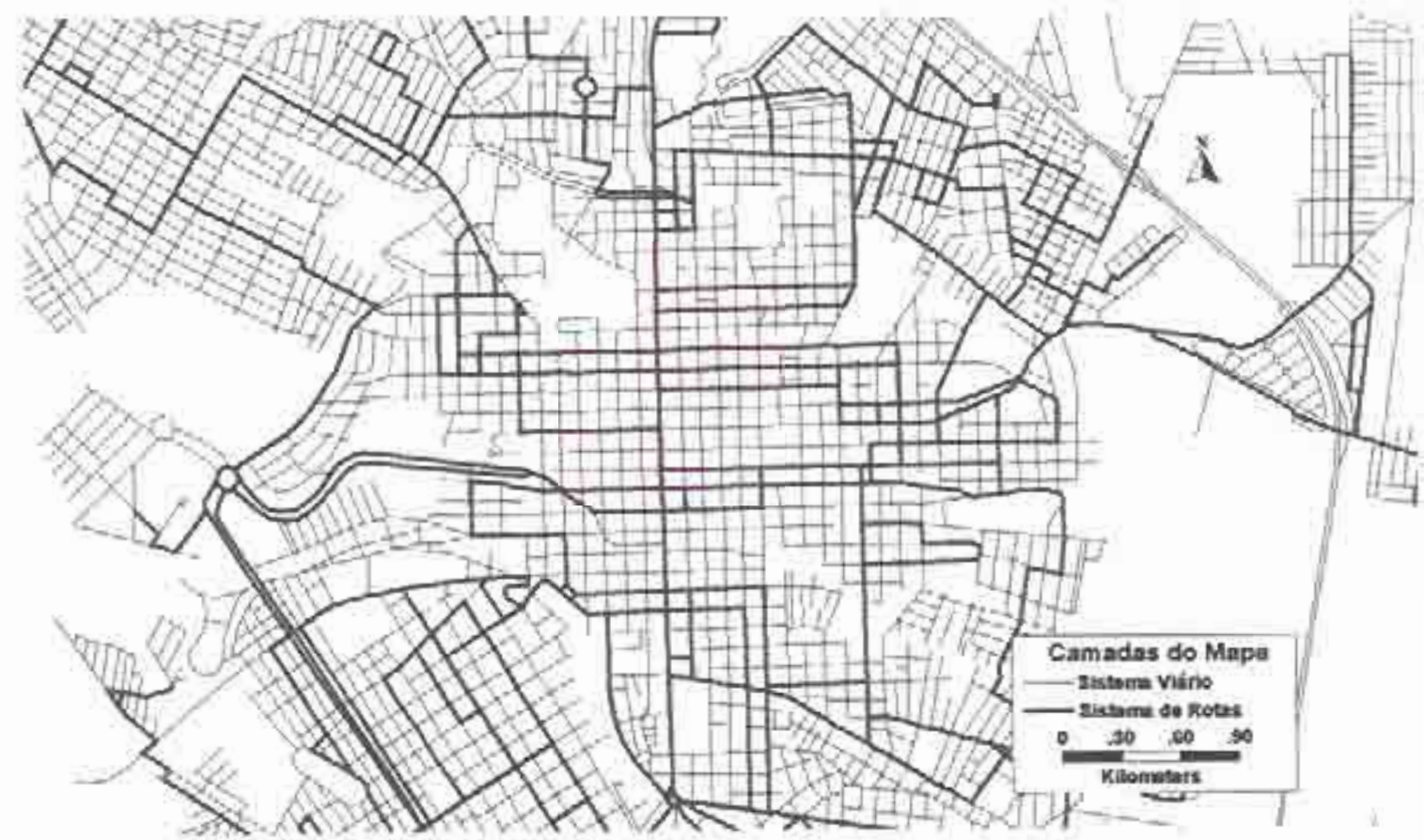

FIGURA 4.8 - Rotas agrupadas utilizando o recurso tracking. 


\section{c) Redes de transporte público e caminhos mínimos}

O TransCAD possui ferramentas especializadas e procedimentos para criar e trabalhar com redes de transporte público. Elas são criadas a partir de um sistema de rotas, utilizando informações das rotas, pontos de parada e a camada básica de ruas, e săo utilizadas para o seguinte (CALIPER, 1996a):

- Sohucionar problemas de caminho minimo:

- Criar árvores de menor caminho;

- Realizar alocação de viagens de transporte público.

Redes de transpone público são similares as outras redes utilizadas pelo TransCAD, uma vez que elas contêm nós e links que indicam caminhos de viagens permissiveis, juntamente com informaçăo sobre custos de atravessar cada link (CALIPER, 1996a),

\subsection{Sumário de Atividades}

Após a apresentação do sistema de consulta de itinerários e a descrição dos procedimentos adotados na metodologia empregada, foi feito um resumo das atividades realizadas. É importante salientar que aqui se encontra a alma do projeto, pois uma vez bem definidas as principais informações, a execução do trabalho se torma mais simples.

1" ETAPA - Obtenção do Mapa em Papel da Cidade de Sảo Carlos - As informaçôes referentes ao sistema viário e nomes dos logradouros foram conseguidas em plantas da prefeitura, em escala 1:10.000.

2" ETAPA - Aprendizado do Softuare - O aprendizado se deu, basicamente, através do pacote đe auto-instrução mencionado em 4.3.1, leitura dos manuais de orientą̧ão e a realização dos exercicios propostos nos manuais do TransC.AD. 
3" ETAPA - Criação da Base de Dados Geográfica - Para viabilizar a utilização do SIG neste projeto, deve-se, em um primeiro passo, criar uma base de dados geográfica na qual constarão todas as informaçōes relevantes à este projeto. Para tanto, foi necessária a criação de uma base de dados de ruas e outra de rotas.

4" ETAPA - Digitalizaçăo da Base de Dados Geográfica Relacionada ao Sistema Viário

- Esta etapa foi favorecida devido á existência da já citada base de dados, digitalizada num projeto anterior (ver item 4.3.4). Na época do início do projeto, esta base continha apenas informações básicas do sistema viário, tais como: um número identificador (ID) para cada link, o comprimento deste link e o sentido.

$5^{a}$ ETAPA - Criação da Rede - Para serem realizadas as análises desejadas, foi necessária a criação de uma rede de transporte utilizando-se recursos disponiveis no software. Com este tipo de rede muitos problemas de transporte podem ser resolvidos, tais como: identificação de caminhos minimos, roteirização de veiculos, localização de instalaçōes, etc.

6" ETAPA - Nomeação dos Logradouros - Após a digitalização da base de dados, houve a designação dos nomes dos logradouros, tendo sido utilizado como base um mapa em papel da cidade de São Carlos. Maiores detalhes sobre a nomeaçăo dos logradouros podem ser encontrados no item 5.22

$7^{a}$ ETAPA - Localização Geográfica de Endereços - Após o término da nomeação dos nomes dos logradouros, foram testados alguns procedimentos específicos utilizando-se a técnica Address Matching. Esta técnica define a posição de um ponto através do nome do logradouro, número e código de endereçamento postal (CEP). No caso deste projeto, a localizaçāo foi feita levando-se em consideração o cruzamento entre vias e o CEP, como será visto no item 5.3.a.

8플 ETAPA - Obtenção dos Itinerários das Linhas - Os itinerários de todas as linhas, que formam o sistema de transporte coletivo da cidade de São Carlos-SP, foram fornecidos pela empresa operadora. 
9: ETAPA - Levantamento de Campo - Algumas informaçôes, como a localização dos pontos de ônibus, tiveram que ser levantadas em campo, para depois serem incorporadas a base de dados geográfica. Maiores detalhes sobre este levantamento podem ser encontrados em 4.3.2.a.

10 ETAPA - Criação da Base de dados Geográfica de Rotas - Esta base de dados foi criada tendo como base o sistema viảrio. sendo constituida pelas linhas de ônibus e pontos de parada.

$11^{*}$ ETAPA - Digitalização da Base de dados Geográfica de Rotas - Utilizando-se uma rotina especifica do softuare para se trabalhar com rotas, os itinerários das linhas de onibus com seus respectivos pontos de parada foram digitalizados, via mouse, tendo como pano de fundo o sistema viário. Durame o processo de digitalizaçâo da base de dados de rotas, surgem campos responsảveis pelo armazenamento de informaçǒes sobre as linhas e pontos, tais como: um número identificador (ID) para cada linha, nome da linha, um múmero identificador (ID) para cada ponto parada, as coordenadas de cada ponto de parada. dentre outras.

12 ETAPA - Preenchimento do Banco de Dados com Informações Referentes às Linhas - Os campos a serem completados na tabela eram código da linha, nome da linha, headway e tarifa. As informaçð̋es necessárias para o preenchimento destes campos foram obtidas junto a empresa operadora. Com estas informaçôes montou-se, a titulo de exemplo, a figura 4.9 .

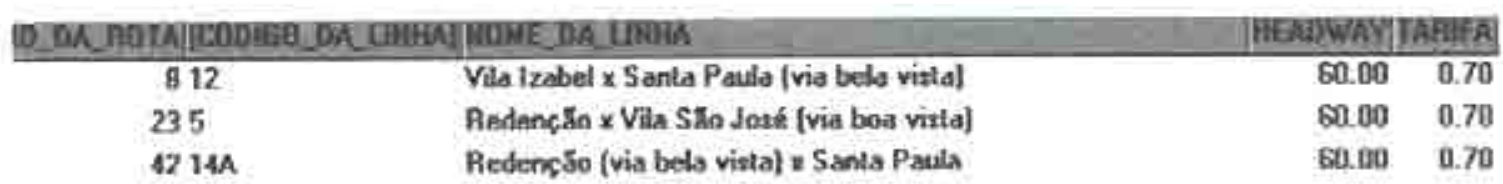

Figura 4.9-Informaçðes adicionais sobre as linhas de ônibus. 
13" ETAPA - Criação da Rede de Transporte Público - Para serem realizadas as consultas de itinerários visando a determinaçâo das rotas ótimas, foi necessária a criaçāo de uma rede de transporte público Maiores detalhes sobre a criação da rede de transporte público podem ser encontrados no item $5.3 \mathrm{C}$

14: ETAPA - Preparaçào de Consultas - Finalmente, pồde-se realizar as consultas sobre a determinação das rotas ótimas entre origens e destinos informados pelos passageiros e fornecendo como saida: mapas, caixas de diálogo e relatórios. Observa-se que o processamento de consultas, hoje proposto em termos de distâncias percorridas para a determinaçåo das rotas ótimas, poderá evoluir para o uso de informaçōes sobre o tempo de percurso, quando este tipo de dado estiver disponivel. 


\section{ESTUDO DE CASO}

Neste capitulo, através de um estudo de caso, pretende-se mostrar uma aplicaçūo prálica do emprego de um $S / G$, no caso o frams $C A L$ ). como suporte ao sisfema de comsulta proposto no item 4.2 .

\subsection{Introdução}

O funcionamento do atendimento a consultas descrito no item 4.2 será demonstrado neste capitulo através da realização de um estudo do caso. Este estudo compreendeu a aplicação do sistema de consulta, apresentado no item 4.2 , ao sistema de transporte coletivo da cidade de São Carlos - SP

De acordo com o objetivo a que se propõe este trabalho, utilizou-se um SIG, o software TransCAD, como ferramenta de apoio para o desenvolvimemto do sistema de consulta em questão. Ao longo deste capitulo também serão comentadas as dificuldades encontradas no emprego de alguns procedimentos do software para este fim.

Inicialmente serão abordados os critérios de definição sobre a área do estudo de caso e os dados utilizados para realização deste estudo. Em seguida, serảo mostrados os procedimentos para a utilização do sistema proposto e, por último, será mostrada uma aplicaçào prática do sistema de consulta e tecidos alguns comentários sobre os problemas observados. 


\section{2 Área do Estudo de Caso}

\subsubsection{Critérios de Definição}

A escolha da área de estudo levou em consideração aspectos como: apoio da administração municipal local e da empresa operadora do sistema de transporte coletivo, estrutura oferecida pelo centro de pesquisa (Universidade) e facilidades para realização dos trabalhos de campo.

Baseando-se nestes criterios, escolheu-se como estudo de caso o sistema de transporte coletivo da cidade de São Carlos, uma tipica cidade de porte médio, que tem uma população de aproximadamente 175 mil habitantes e está localizada próxima a região central do estado de São Paulo (figura 5.1).

O sistema atual de transporte coletivo por ônibus é operado por uma única empresa, com uma frota de 100 veiculos que operam em 46 linhas e transportam cerca de 50 mil passageiros (média por dia útil). A cobertura do sistema de transporte coletivo é mostrada na figura 5.2 


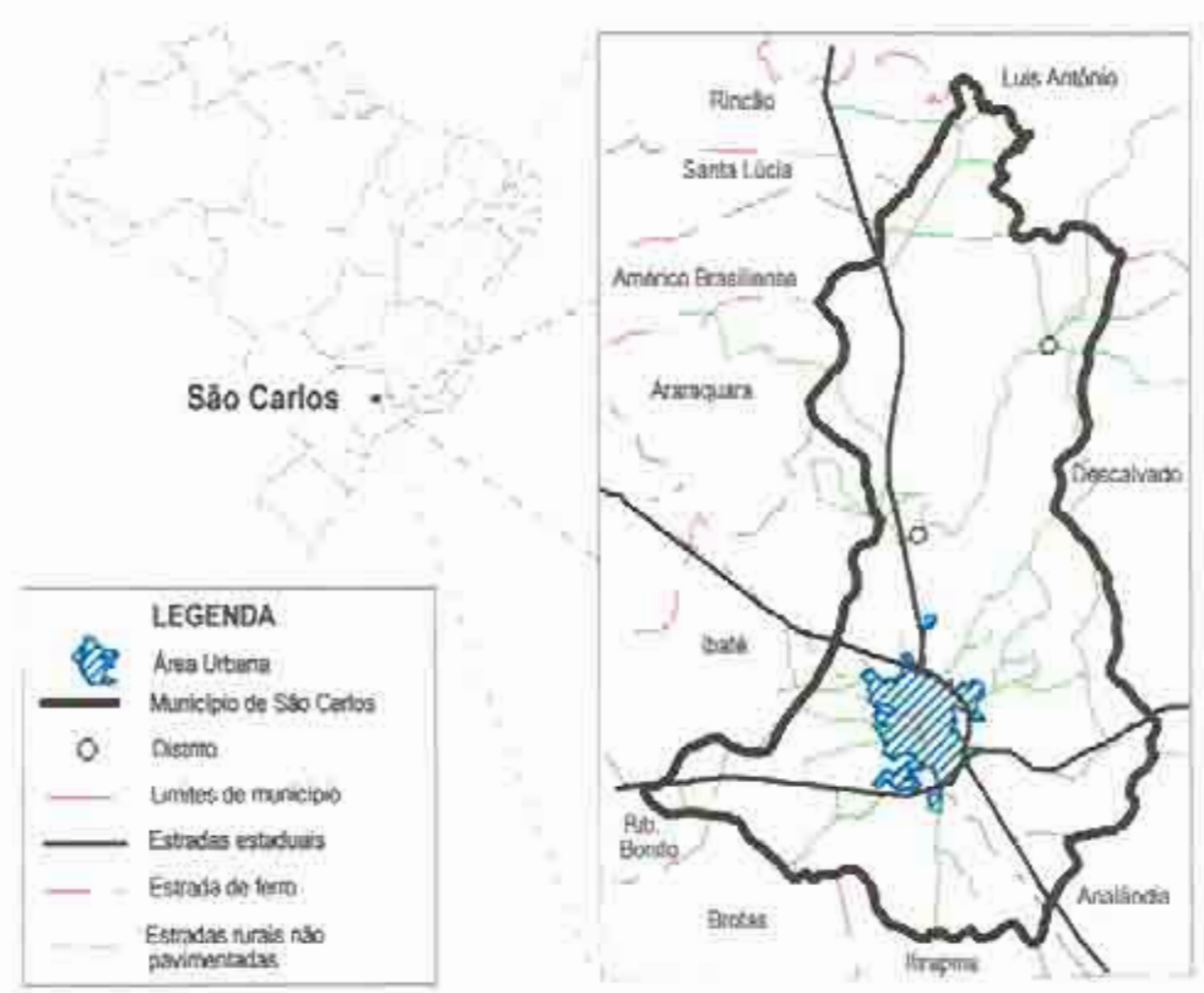

FIGURA 5.1 - Localização da área de estudo. 


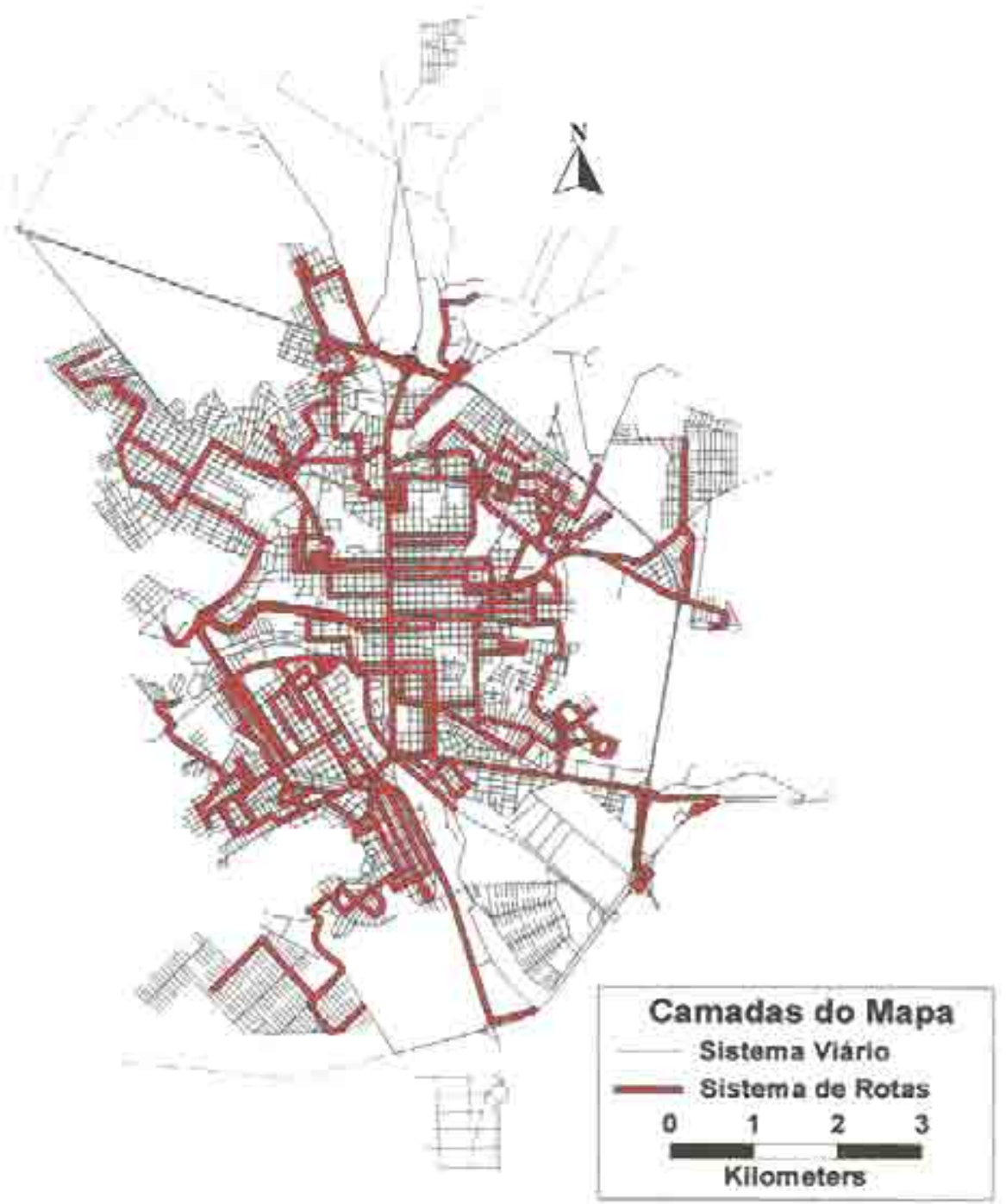

FIGURA 5.2 - Sistema de transporte coletivo de São Carlos.

\subsubsection{Dados Utilizados}

Para utilizar as informações referentes ao sistema viário é necessário a existência de uma base de dados viária da cidade. Esta base foi obtida num projeto anterior (ver item 4.3.4) e já se encontrava compatível para ser utilizada pelo software TransCAD. sendo constituida pelos eixos das vias, aos quais estavam associados campos 
responsáveis pelo armazenamento de informaç̋̄es básicas como: um número identificador (ID) para cada link, o comprimento deste link c o sentido. Nenhuma informaçào de cndereços, ou de qualquer outra natureza, estava disponivel na mesma.

Os nomes dos logradouros foram acrescentados à base de dados empregada. Os logradouros podem set formados por um link ou por uma seqüència de links (figura 5.3). Vitilizando-se comandos de seleção é possivel nomeä-los, basta apenas selecionar todo os segmentos que os compõem e utilizar outro comando para completá-los com o nome de uma rua, avenida, travessa, praça, etc. (CALIPER, 1996b). A principal dificuldade encontrada na colocaçăo dos nomes dos logradouros foi a inexistếncia no mapa de alguns nomes de logradouros $\mathrm{em}$ bairros periféricos.

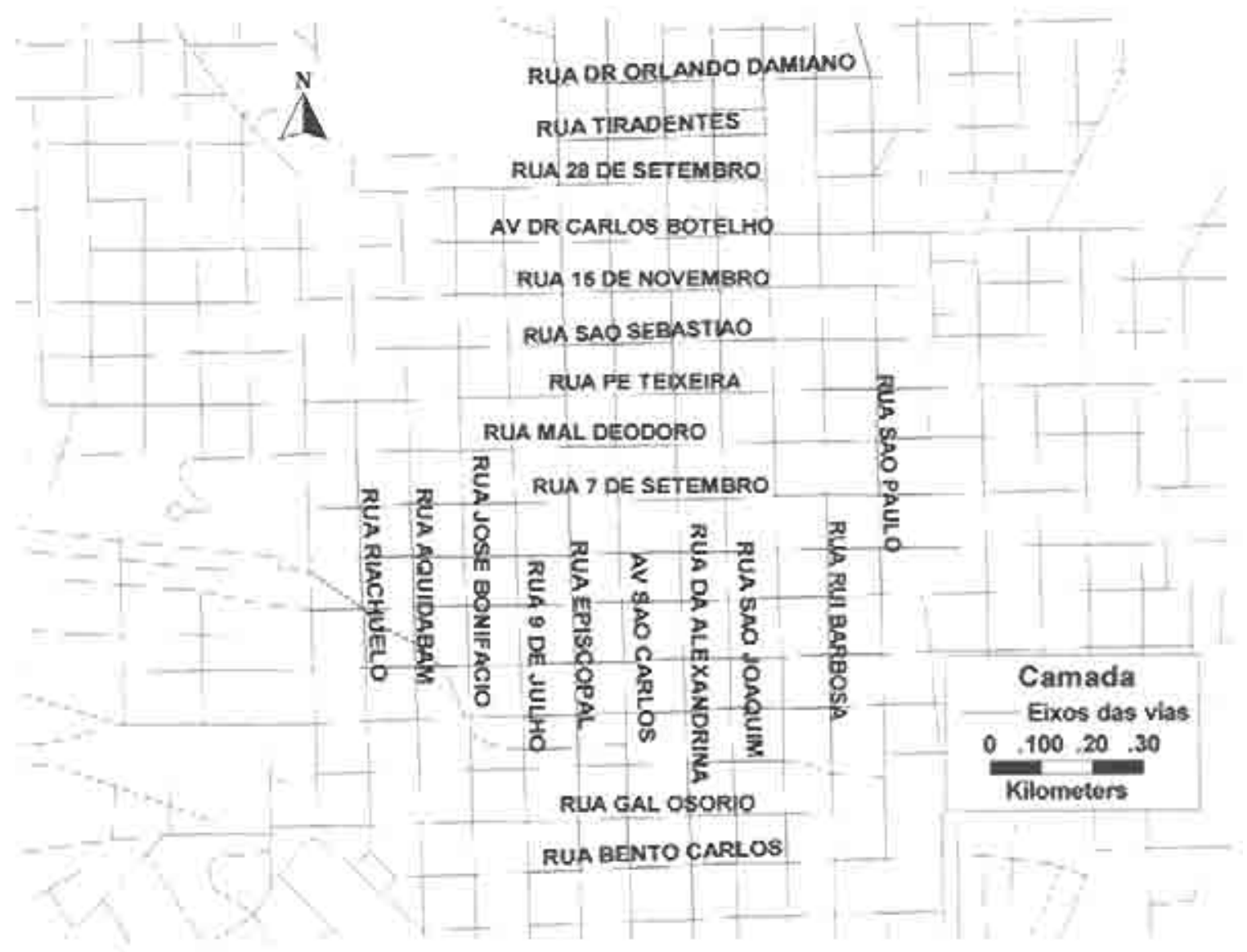

FIGURA 5,3 - Parte da base de dados de ruas contendo os nomes dos logradouros. 
Para poder utilizar o comando de combinação de endereços faltava apenas acrescentar à base de dados o CEP. Como nào havia, na época do inicio do projeto, informações detalhadas referentes ao CEP, adotou-se um único valor para todos os nomes dos logradouros para que fosse possivel tealizar a busca de endereços

Os itinerários das linhas e pontos de parada também foram adicionados á base de dados. Os pontos de parada são representados em SIG como uma camada de pontos A maneira mais simples de se cadastrar pontos de parada é através da marcaçăo direta sobre a base de dados de rotas Já as rotas de ônibus sảo representadas como uma camada de linhas, ou seja, correspondem a uma sequência de links por onde passam as rotas e são digitalizadas sobre a base de dados de ruas.

\subsection{Procedimentos Adotados}

Como o trabalho consiste em localizar a origem e o destino informados pelo passageiro, para depois determinar o caminho minimo, via ônibus, entre estes dois pontos, escolheu-se a rotina que trata de redes de transporte público e caminhos minimos. Para que se pudesse utilizar esta rotina foram necessárias mais duas, a saber, combinação de endereços e sistema de rotas. Para isto. fez-se uma junção dessas rotinas, ou seja, com os resultados de uma rotina, alimentou-se a outra, a fim de se obter os resultados gerados pelo soffware que serão mostrados na próxima seção. A seguir será feita uma breve descrição das rotinas empregadas.

\section{a) Combinação de Endereços (Address Matching)}

Para tornar a localização geográfica de endereços mais eficiente, os nomes dos logradouros foram digitados novamente por uma equipe formada por 6 pessoas, onde procurou-se assegurar uniformidade nos nomes das ruas, buscando-se erros de grafia, A 
base de dados foi dividida em setores e cada componente da equipe ficou responsável pela colocaçāo dos nomes dos logradouros em seu setor e em pouco mais de três semanas a base de dados de ruas estava concluida. Houve muito empenho por parte da equipe nesta fase do trabalho, uma vez que esta base de dados seria utilizada para demonstrar o sistema de consulta de itinerários numa feira de tecnologia em São Carlos.

A localização por endereço (Address Matching ou Geocoxting) é a técnica pela qual se define a posição de um ponto atravès do nome do logradouro, número e código de endereçamento postal (CEP). Para fazer uso deste recurso é necessário que a base do sistema viário possua informaçōes sobre os nomes dos logradouros, numeração e CEP associadas a cada $l m k$. Os campos de numeração devem informar o menor valor par, o menor valor impar, o maior valor par e o maior valor impar para cada segmento (PINTO \& LINDAU, 1997).

Os sistemas de localizaçāo por endereço podem funcionar de forma automática e semi-automática. No modo automático o sistema localiza todos os endereços que conseguir em um mapa (ver figura 4.5) e reporta o resultado numa tabela (ver figura 4.6) em que indica todos os registros que năo foram localizados, se por acaso existirem. No modo semi-automático, quando um registro nâo é encontrado, o sistema oferece ao usuario opções de localizaçåo possiveis (PINTO \& LINDAU, 1997).

Como jả foi mencionado no item 4.2.2, o passageiro poderá informar a sua localizaçâo e seu destino das seguintes maneiras: endereco completo, trecho, ponto de referência ou através de cruzamento de vias. A opção em localizar a origem e o destino. informados pelos passageiros através de cruzamento e não por endereço completo, deveu-se ao fato de que a base de dados de endereços ainda não está totalmente concluida, uma vez que ela é comum a diferentes projetos, que se encontram em diferentes fases de desenvolvimento.

Para que a localização por cruzamento possa ser utilizada, é necessaria a existência de regras para a nomenclatura dos logradouros e para o CEP. Os nomes dos logradouros que formam cada cruzamento devem estar separados pela palavra $A N D$ e 
apresentar o mesmo CEP, podendo-se utilizar o formato brasileiro com CEP para 8 digitos: Estas regras devem ser seguidas, pois se as convençōes não forem obedecidas, os cruzamentos não serão localizados.

Vale ressaltar que o comando Address Matching apresenta um algoritmo de busca fonética, não existindo problemas com letras maiusculas/minúsculas, com abreviaturas e, ainda, com erros de digitação como trocas de " $s$ " por " $z$ ", ou "e" por "i", etc Com relaçăo ao comando Select by condition deve-se levar em consideração as mesmas regras usadas pelo TransC AD no banco de dados de ruas

Segundo empresas de consultoria que trabalham com o software TransCAD, para se conseguir uma maior eficiência do comando para a localização geográfica de endereços no formato brasileiro, seria necessảria a implementação de um algoritmo utilizando o kat de programação GISDK disponivel no TransCAD.

\section{b) Sistema de rotas (Route System)}

Como o trabalho está diretamente ligado à operaçào do sistema de transporte coletivo, procurou-se escolher uma rotina especifica do software para se trabalhar com rotas. Antes que as linhas de onibus c os pontos de parada fossem cadastrados tendo como base o sistema viảrio, foi necessảria a criação de uma rede de transporte, utilizando-se os links da camada na qual o sistema de rotas é baseado, no caso o sistema viário. Após a criação da rede de transporte, utilizando-se as ferramentas de edição de rotas, foram digitalizados (via mouse) na base de dados de ruas os itinerarios das linhas e os pontos de parada.

Após a digitalização de todas as linhas e paradas que compōem o sistema de transporte coletivo da cidade de Sảo Carlos - SP, observou-se, na tela do computador, um emaranhado de linhas de ônibus provocando uma certa confusâo na visualização do mapa em formato digital. Para solucionar este problema utilizou-se o recurso chamado 
tracking, que permite a sobreposiçào de rotas, possibilitando assim uma melhor visualizaçảo e análise da rede de transporte coletivo.

A principal dificuldade observada em utilizar o módulo Route System deveu-se a ineficiência ao se trabalhar com redes, no que diz respeito a atualizaçåo de dados no mapa Por exemplo, quando for necessario digitalizar as novas linhas de ônibus que servirão a um novo bairro, poderão ocorrer problemas constantes ao se utilizar a rede (usada para criar o sistema de rotas) na atualizaçào do sistema de transporte coletivo. A criaçåo de um novo bairro implicará na atualizaçåo de dados na base do sistema viário, ou seja, na digitalizaçào das novas ruas e avenidas. Uma vez concluida esta etapa e na tentativa de traçar as novas rotas de ònibus que servirão aquele bairro, geralmente ocorria uma falha geral, sendo necessário reiniciar o programa. Espera-se que a versảo 3.1 do TransCAD, lançada recentemente, corrija esta falha.

\section{c) Redes de transporte público e caminhos mínimos (Transit Network and Shortest Paths)}

Este módulo tem como objetivo encontrar o caminho minimo entre pontos de parada na rede de transporte público, baseado em atributos de rede, tais como: tempo, distância e um valor monetário atribuido ao custo de viagem. Para tanto, é preciso criar uma rede de transporte público, utilizando-se informaçōes das rotas, dos pontos de parada e da camada básica de ruas. $O$ soffware utiliza esta rede para determinar o caminho minimo entre pontos de parada no mapa (CALIPER, 1996a).

Uma vez definidos os campos da camada básica de ruas, de rotas e pontos de parada, configurada a rede de transporte público e estando ativa a camada de rotas, procedeu-se a determinação de caminhos minimos, baseados na distância, via ơnibus, entre vários pontos da cidade. Após as primeiras análises, verificou-se que nem sempre era possivel realizar a viagem em apenas uma linha, sendo necessário realizar 
transbordos ao longo do trajeto e fazer combinaçōes entre linhas que servem à origem e ao destino.

As vantagens do uso de redes de transporte público, em relação a simplesmente utilizar-se dos sistema de rotas, sâo, principalmente, a possibilidade de se trabalhar com transferências entre linhas (ou entre modos) e a determinação de itinerários de menores custos. Utilizando-se redes de transporte público e estrutura tarifária é possivel resolver problemas de caminho mínimo entre pontos de parada num sistema de rotas ou entre zonas de tráfego (CALIPER, 1996a).

A próxima seção descreve o funcionamento do sistema de consulta de itinerários. com base na operação de um sistema de transporte coletivo no mundo real com auxilio das ferramentas descritas anteriormente.

\subsection{Aplicação do Sistema de Consulta de Itinerários}

Este sistema tem como finalidade atender a pessoas que queiram deslocar-se de ónibus de um ponto a outro na cidade de Săo Carlos. A idéia é de se colocar um número de telefone a disposiçâo das pessoas para que elas possam saber que ônibus tomar para

se deslocar de um local para outro. Ele compreende duas etapas: a primeira é a localização geográfica da origem e do destino informados pelos passageiros e a segunda consiste em determinar a rota ótima, via ónibus, entre estes dois pontos. 


\section{a) $1^{\text {a }}$ Etapa - Localização geográfica}

Ao ligar, o passageiro dirá em qual esquina (cruzamento entre vias) se encontra e para qual deseja se locomover. De posse desta informaçâo o operador digitará na tela abaixo a origem e o destino informado:

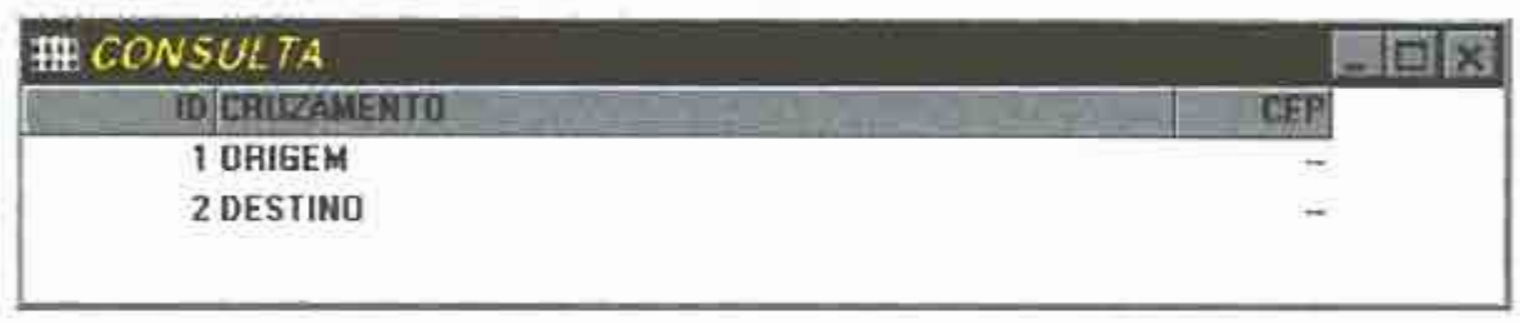

FIGURA 5.4 - Modelo utilizado pelo software para a localizaçào geográfica do passageiro.

Suponha que um passageiro esteja próximo ao cruzamento das ruas Miguel Petroni e Dona Maria Jacinta e queira deslocar-se para o cruzamento das avenidas São Carlos e Raimundo Correa. A tela acima ficaria da seguinte maneira, após ser preenchida pelo operador do sistema.

\begin{tabular}{|c|c|}
\hline Fib CONSUULAA & 2 E] \\
\hline 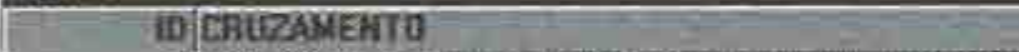 & DEP \\
\hline 1 BUA MIGUEL PETRONI AND RUA D MARIA JACINIA & 13560000 \\
\hline 2 AV SAO CARLOS AND AV RAIMUNDO CORHEA & 13560000 \\
\hline
\end{tabular}

FIGURA 5:5 - Tela contendo a origem e o destino fornecidos pelo passageiro. 
Partindo-se do pressuposto que a localização geográfica da origem e do destino informados pelo passagciro tenha sido realizada com sucesso, o processamento prosseguirá para a etapa seguinte.

\section{b) 2 Etapa - Determinaçấo do caminho mínimo}

Para solucionar problemas de caminho minimo, o operador desenhará um ćrculo, com o mouse, em volta do ponto de origem e outro em volta do ponto de destino, e em poucos segundos será mostrada a rota ótima. TransCAD encontrará a parada na qual a viagem deve começar, determinará $\mathrm{a}(\mathrm{s})$ rota(s) que será(serão) usada(s) para chegar ao destino, e escolherá a parada onde deverá ser efetuado o desembarque (CALIPER, 1996a),

Ao resolver problemas de caminho minimo pela primeira vez, o programa perguntará o nome da tabela na qual os resultados serăo armazenados. Quando vários caminhos minimos forem solucionados, os resultados serăo todos armazenados nesta tabcla c mostrados como parte de uma camada (C.AL.IPER, 1996a).

O programa produz uma série de instruçôes para cada caminho minimo, indicando o local de embarque de cada rota, o número de paradas durante o trajeto e o local do desembarque de cada rota (ligura 5.6).

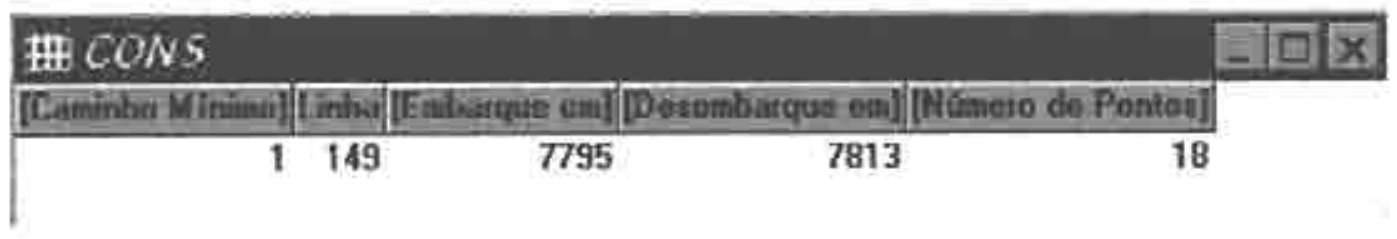

FIGURA 5.6 - Tela com resultados do caminho minimo. 
Os resultados obtidos sobre a consulta de itinerários são mostrados de duas maneiras: através de uma caixa de diálogo e graficamente em um mapa. A figura 5.7 corresponde á saida dos resultados gerados pelo software. Esta saida é feita através de uma caixa de diálogo que contém as seguintes informaçốes, que serào comentadas a seguir:

- Custo total generalizado de viagem entre cada origem e destimo, baseado no tempo de vagem, na distanncia ou qualquer outra variável definida (Tolal $\$$ Cost);

- Tarifa paga pela viagem (Fare);

- Número de transferéncias requeridas para fazer a viagem (Xfers);

- Tempo gasto esperando para embarcar no onibus (Wait Time);

- Caracteristicas do menor caminho (Skim Values);

- Instruçōes para rcalizar a viagem (Directions).

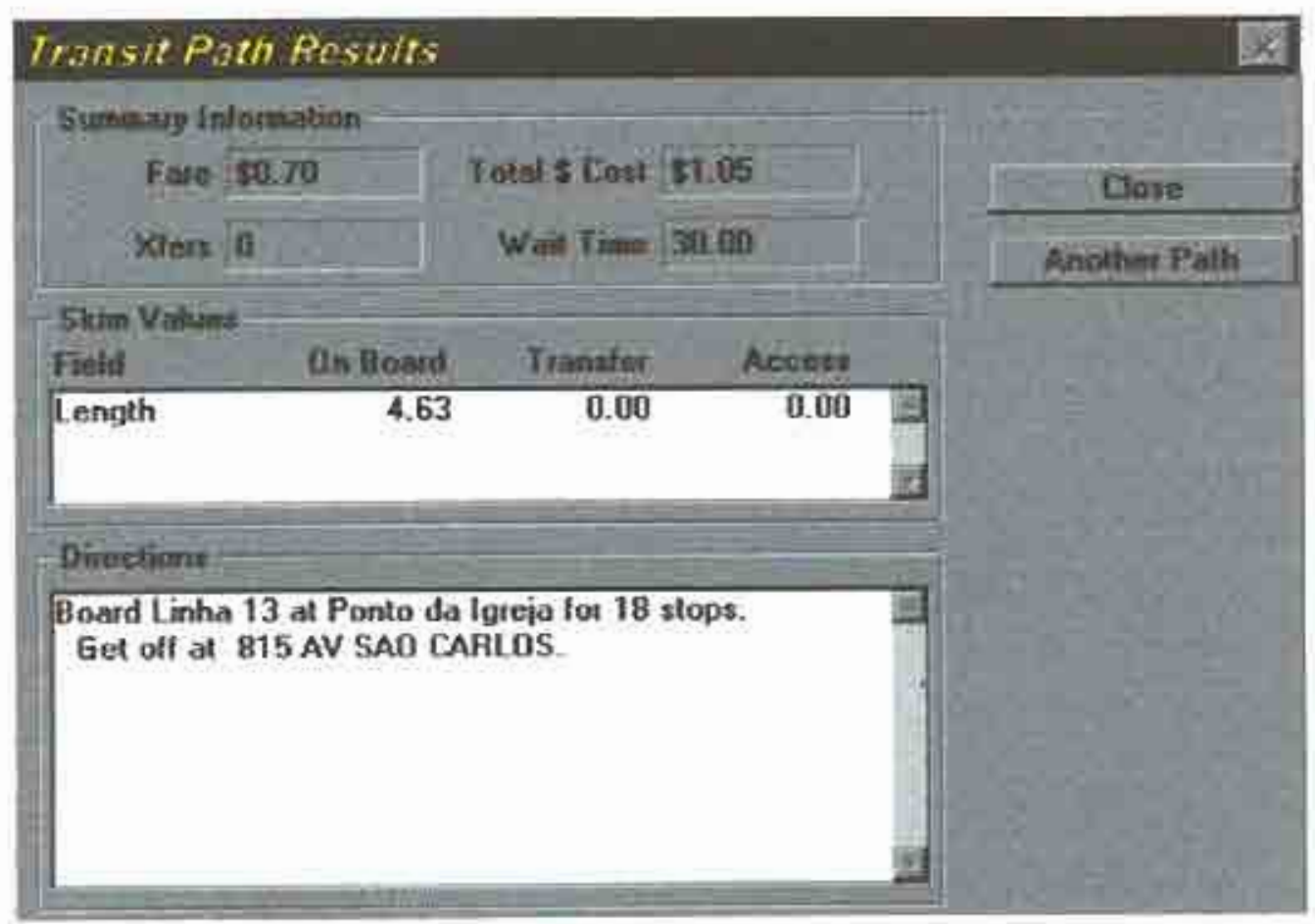

Figura 5.7-Saida dos resultados gerados pelo soffware sobre a consulta de itinerários. 
Para resolver problemas de menor caminho, deve-se definir o atributo de rede que contém a impedância ou custo total generalizado. Este atributo pode ser o tempo de viagem, mas em algumas circunstâncias pode ser a distância ou qualquer outra variável $O$ TransCAD, quando encontra o caminho minimo, considera a variável escolhida juntamente com o tempo de espera e o custo efetivo gasto Deve-se também fornecer informação sobre valores relativos entre tarifa e impedância. Por exemplo, se a escolha for minimizar o tempo de viagem, deve-se atribuir um valor monetário ao tempo (por exemplo, RS 0.01 por minuto). Agora, se a escolha for minimizar a distância, deve-se atribuir um valor monetario à distància (por exemplo, R\$ 0.01 por $\mathrm{km}$ percorrido). Estes valores serão adicionados ao preço da tarifa para a composição do custo total generalizado de viagem (CALIPER, 1996a).

A tarifa é definida em campos associados à camada do sistema de rotas, podendo suponar vários tipos de tarifa (única ou diferenciada por zonas). $\mathrm{O}$ número máximo de transferências pode ser limitado para a determinaçāo do menor caminho. Assim como a tarifa, o tempo maximo de espera também é definido em campos associados á camada do sistema de rotas e pode-se atribuir a ele um valor máximo permitido na soluçăo do menor caminho (CALIPER, 1996a).

As caracteristicas do menor caminho contêm o atributo que foi minimizado para a determinação do menor caminho e as características associadas a ele. As inștruçōes sobre como proceder para realizar a viagem contêm informações sobre a(s) linha(s) utilizada(s), denominação dos pontos de embarque e desembarque e o número de paradas durante o percurso. Para gerar estas instruçðes, o programa precisa de uma descriçảo da localização de cada ponto de parada. Esta informação pode ser armazenada em campos que contêm informações sobre os pontos de parada. Caso esta informação não seja tomecida, o programa compreenderá que a localizaçăo será baseada na camada de ruas (cruzamento mais próximo) (CALIPER, 1996a).

A figura 5.8 mostra a representaçăo gráfica do caminho minimo entre dois pontos dados, obtida utilizando o sistema de consulta. 


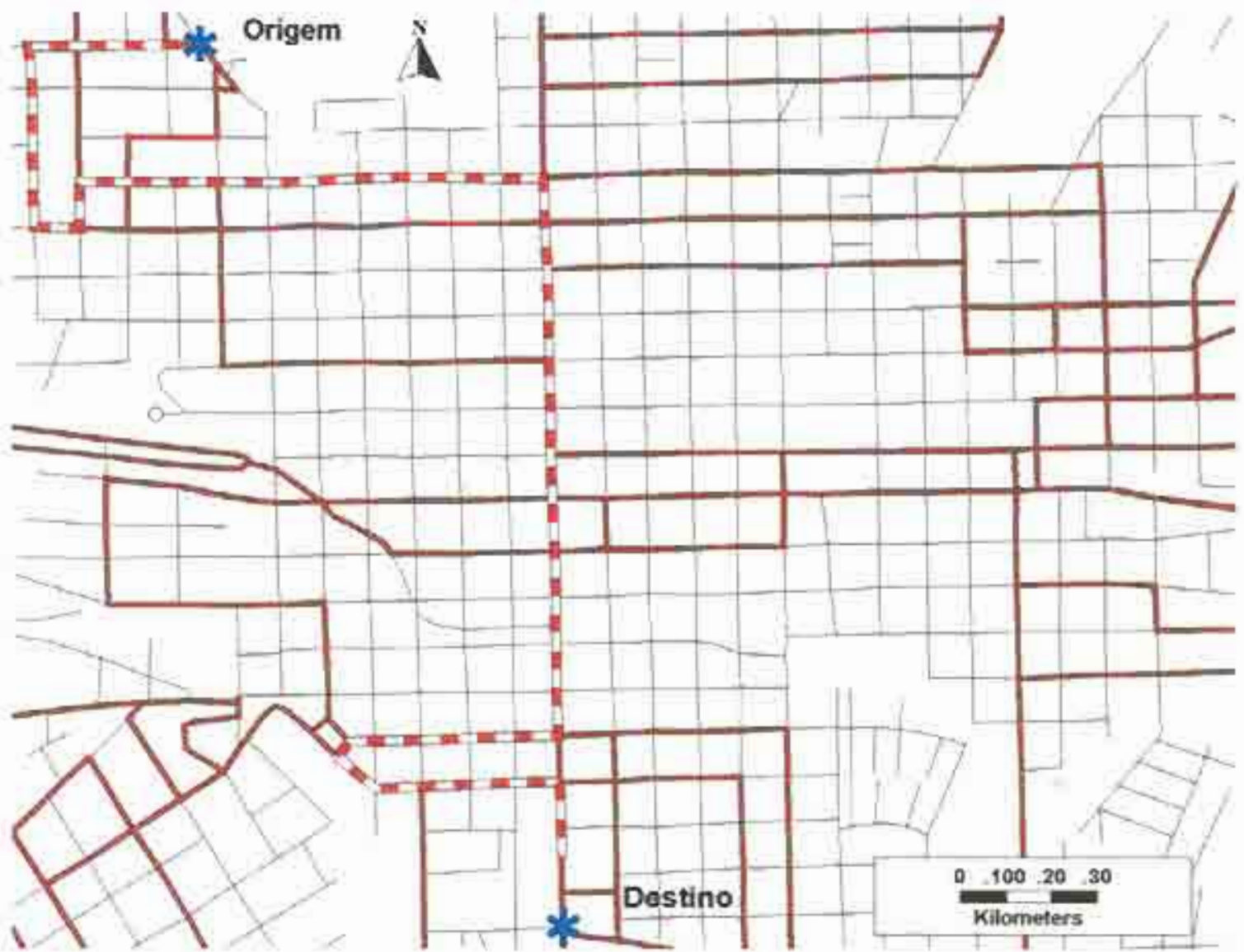

Figura 5.8 - Rota otima representada entre origem e destino fornecidos pelo passageiro.

\subsection{Problemas Observados}

O processo de coleta e levantamento de dados foi estudado detalhadamente, para que se tivesse um uso racional dos recursos envolvidos. Para este levantamento, foram utilizados um veiculo particular e a mão-de-obra de pessoas engajadas em diversos projetos de planejamento de transportes desenvolvidos na Área de Pós Građuação em Transportes na EESC-USP. Mesmo assim houve dificuldades na obtenção dos dados, uma vez que nas regiōes mais periféricas, onde as linhas nâo estâo consolidadas e a infra-estrutura urbana é deficiente, muito tempo é perdido na obtençāo de informaçōes. 
No caso particular, a nào existểncia de marcos de identificaçảo em alguns pontos de ônibus e a ausência dos nomes dos logradouros trouxeram dificuldades inesperadas

Para que possam ser passadas informaçoes aos passageiros sobre os pontos de embarque e desembarque, è preciso saber exatamente onde se localizam os pontos em que us passageiros podem entrar e sair do sistema. Uma maneira de se fazer isso, na prática, seria associar a todo ponto um múmero, ou ainda uma referência auxiliar para facilitar a identificaçâo in loco (por exemplo, ponto $\mathrm{n}^{2} 10$, ponto da igreja, em frente a farmácia, etc).

A base de dados atual descrita no item 5.2 .2 prejudica o desempenho da técnica Adltress Matching (Combinação de endereços) para a localizaçào geográfica de endereços, uma vez que o tempo de resposta (aproximadamente $40 \mathrm{seg}$.) dificulta a aplicação prática do sistema de consulta de itinerários Com a incorporação de informações sobre a numeração e o CEP a esta base de dados, o tempo de resposta deverá cair para aproximadamente $5 \mathrm{seg}$. Ainda sobre a localização geográfica de enderecos, é importante ressaltar que devem ser levadas em consideraçāo as regras definidas em $5.3 \mathrm{a}$, pois se os padrões nào forem seguidos, os endereços não serảo localizados

Com relação a representação gráfica da localização da origem e do destino informados pelos passageiros, o comando Address Matching apresenta uma falha, uma vez que ele não diferencia no mapa a origem do destino

O sistema de consulta de itinerarios, tal como está aqui concebido, tem o inconveniente de não ser totalmente automático, pois para isso, seria preciso juntar as rotinas cmpregadas pelo software em um único procedimento $O$ ideal seria que, ao localizar a origem e o destino informados pelo passageiro, o sistema já determinasse o caminho minimo, via ônibus, entre estes dois pontos Para tanto, seria necessário explorar recursos de linguagens de programação disponiveis. 
A seguir serão feitos alguns comentários sobre 0 aprendizado da linguagem de programação, dificuldades encontradas, busca de soluções, o que se pretendia fazer, perspectivas para futuros desenvolvimentos e um sumário das principais etapas do projeto

Por se tratar de um novo instrumento de trabalho e por não se dispor de pessoas com o conhecimento suficiente a respeito da linguagem de programaçâo GISDK para encaminhar os primeiros passos, o treinamento se deu, basicamente, na forma de autoaprendizado. Os árduos passos iniciais para o conhecimento da estrutura básica do sistema foram a leitura dos manuais de programaçăo e a realizaçâo de poucos exercicios disponiveis em alguns capitulos dos mesmos.

Diante da abrangência e da complexidade das funçôes em Caliper Script (ver item 3.7) existentes nos manuais (CALIPER, 1995), procurou-se uma funçăo especifica que fizesse o mesmo que o comando Address Matching (ver item 5.3.a). Após uma análise bem detalhada, chegou-se a conclusào que nào existia esta função disponivel na versào 3.0 do TransC $\mathrm{AD}$. Diante desta situaçăo, foram feitos contatos com empresas de consultorias, universidades e correspondéncia via e-mail com a equipe de suporte técnico do TransCAD, buscando o esclarecimento de algumas questōes que permaneciam pendentes.

Após algum tempo de espera, foram recebidas as seguintes respostas, fomecidas por uma empresa de consultoria e pelo fabricante do produto, respectivamente:

"(...) através do GISDK, vocè consegue implementar um algoritmo que faça o mesmo que a opçâo Locate by Address, mas não existe uma fumção que faça isso diretamente. A propria opção Locate by Address foi desenvolvida em GISDK, pois todo o TransCAD o fot, mas o seu processamento engloba um algoritmo. Com certeza a implementação $\dot{e}$ possivel, prois temos um produto desenvolvido um GISDK. que faz a localização geografica de endereços (para o formato brasilemo), e para isso fizemos a implementação de um algorimo (...)" (empresa de consultoria) 
"(...) There is an Add-in to the GISDK that permits addrexs-level geocoting (...)" (fabricante)

A função em Caliper Scripl, responsảvel pela localizaçăo geográfica de endereços, foi adquirida junto ao fabricante como parte do suporte técnico. Uma vez estudada e explorada esta função, o passo seguinte seria a incorporação da rotina de caminho minimo, A ideia era amarrar as coordenadas dos pontos selecionados pelo comando de localizaçâo geográfica (ver figuras 4.5 e 4.6 ) a rotina de caminho minimo, ou seja, no momento em que o programa localizasse os pontos consultados, ele determinaria a rota ótima entre estes dois pontos. Além da automatizaçāo de rotinas, os recursos de programação também permitem a personalizaçăo do programa, através de menus, caixas de dialogo, caixa de ferramentas, etc.

Devido a limitaçào de recursos e, principalmente, de tempo, além das dificuldades encontradas em utilizar a linguagem de programaçào, Caliper Scripl, o estudo apresentado se restringiu em utilizar os procedimentos adotados descritos em 53 , sem juntar as rotinas empregadas pelo software em um único procedimento, explorando recursos de linguagens de programação disponiveis.

Houve, é certo, limitaçōes em razão de se tratar de uma nova tecnologia Os primeiros passos já foram dados na tentativa de aperfeiçoar o sistema proposto, que jamais poderá ser considerado como um elo fechado, acabado. Novas idéias surgirão e necessitarão de soluçŏes mais eficientes, que os planejadores de transportes terão que tomar. Sob esta ótica, não se teve a pretensão de abordar o tema em sua plenitude, e sim, de apresentar pequenas luzes para a comunidade cientifica, na certeza de que novas idéias serào lançadas, completando assim, lacunas que nảo foram preenchidas, apesar dos significativos esforços envidados neste sentido. 
Por fim, a tabela 5.1 mostra um resumo das principais etapas do projeto e o tempo gasto em cada uma delas, com o intuito de orientar projetos futuros.

TABELA 5.1 - Cronograma da principais etapas do projeto.

\begin{tabular}{|c|c|c|c|c|c|c|c|c|c|c|c|}
\hline & \multicolumn{8}{|c|}{1997} & \multicolumn{3}{|c|}{1998} \\
\hline ETAPASIMESES & maio & jun & jul & ago & set & out & nov & dez. & jan & fev. & mar. \\
\hline Aprendizado do software & \pm & \pm & 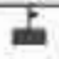 & & & & & & & & \\
\hline $\begin{array}{l}\text { Digitalização da base de } \\
\text { dados viária da cidade }\end{array}$ & & & & 1 & & & & & & & \\
\hline $\begin{array}{c}\text { Nomeação dos } \\
\text { logradouros }\end{array}$ & & & & & \pm & & & & & & \\
\hline Levantamento de campo & & & & & 1 & 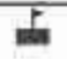 & & & & & \\
\hline $\begin{array}{c}\text { Digitalizaçăo da base de } \\
\text { dados de rotas }\end{array}$ & & & & & \pm & \pm & & & & & \\
\hline $\begin{array}{l}\text { Implementação de rotinas } \\
\text { de consulta no software }\end{array}$ & & & & & & \pm & \pm & & & & \\
\hline $\begin{array}{c}\text { Aprendizado da } \\
\text { linguagem de } \\
\text { programaçāo GISDK }\end{array}$ & & & & & & & & 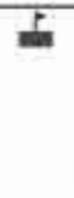 & \pm & 1 & 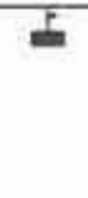 \\
\hline
\end{tabular}

'Exla etapo foi beneficiada devido a existéncia da ja citada tase de dados, digitalizada nuan projeto anterior fvet item $4,3,4)$. 


\section{CONCLUSŌES E RECOMENDAÇÕES}

A realizaçào deste trabalho foi motivada pela falta de informaçōes sobre o sistema de transporte público com o qual se defrontam os passageiros, com a perspectiva de cstudar formas de facilitar o acesso a estas informaçôes de maneira rápida e eficiente, utilizando-se o Sistema de Informações Geograficas (SIG), O fato de que essa tecnologia está em processo imtenso de difusão, e que o seu uso para o planejamento, o projeto, e a operaça de sistemas de transporte se torma progressivamente imprescindivel aos tomadores de decisāo, levou a sua utilização neste trabalho,

O propósito deste trabalho se fundamentou em fornecer subsidios para a implantação de um sistema de informaçóes aos passageiros do sistema de transporte coletivo (sistema de consulta por telefone), baseado num SIG, oferecendo informaçס̃es desde a localizaçào dos pontos de parada de ônibus até a determinaçăo de rotas ótimas, via onibus, entre a origem e o destino informados pelos passageiros. Desta forma, escolheu-se um software de SIG. denominado TransCAD. que foi o responsável pelas análises conduzidas neste trabalho.

O TransCAD se destacou como compilador de todas as caracteristicas físicas do sistema de transporte coletivo objeto de estudo, como processador dos dados de entrada para a modelagem do problema e como ferramenta de apoio para as análises desejadas.

Por outro lado, as grandes dificuldades encontradas no uso do TransCAD deveram-se à interface ainda pouco eficiente existente na localizaçăo geográfica de 
endereços e ao tempo de processamento; traballhosa linguagem de programação para não programadores; adaptação à realidade brasileira; e a ineficiência ao se trabalhar com redes, no que diz respeito a atualização de dados no mapa. Do exposto, conclui-se que o SIG, no caso o TransCAD, apresenta-se como instrumento capaz e importante para subsidiar um sistema de informaçōes aos passageíros do sistema de transporte coletivo. uma vec que os problemas detectados foram principalmente na operaçăo e năo de resultados obtidos pelo sistema.

A aplicaçẫo do sistema de consulta de itinerários mostrado no capitulo anterior. utilizando dados reais do sistema de transporte coletivo da cidade de São Carlos-SP. mostrou a viabilidade de sua utilização. No entamto, para que este sistema possa ser aplicado na prática, seria interessante o desenvolvimento de uma melhor interface entre - TransCAD e o operador do sistema de consulta de itinerários, a fim de facilitar a operação do sistema e o fornecimento de informações aos passageiros. Esta interface pode ser conseguida utilizando-se o módulo de programação do TransCAD, chamado GISDK, que está permitindo um novo horizonte no tratamento e consulta de dados.

A experiência de desenvolvimento para implantação de um sistema de informações para usuários de transporte coletivo relatada ao longo deste trabalho, talvez interesse àquelas instituiçôes que estejam pensando em iniciar o processo de escolha $\mathrm{e}$ uso de um software de SIG para este tim.

Para se conseguir êxito na implantaçâo de um sistema de consulta, algumas etapas devem ser consideradas. Primeiramente cada organizaçào deve definir que tipos de uso e benefícios podem ser exequíveis e prioritários, atendendo as condiçốes locais, $\mathrm{e}$ a partir de então estabelecer metas especificas para o projeto. Deve-se também ter disponivel uma estrutura mínima que possibilite o desenvolvimento do projeto e seja capaz de produzir resultados que demonstrem os beneficios gerados pelo sofiware. A equipc deve ser multidisciplinar. porém é imprescindivel que se tenha mão-de-obra qualificada. Outro aspecto a ser apontado é o planejamento do trabalho, que deve ter etapas bem definidas, de forma a garantir objetivos claros e mensuráveis. Outro dado 
primordial é o contato com pessoas e empresas que utilizam o software de SIG para troca de experiências. Esta relaçâo é fundamental, uma vez que eventuais problemas podem ser solucionados. Deve-se também. na medida do possivel, fazer criticas ao sistema e a sua implementação para avaliar o conjunto de decisðes tomadas.

Os resultados oblidos até o momento indicarn que pode ser viável implantar um sistema de consulta dessa natureza em cidades de porte médio, sem grandes investimentos, desde que haja mão-de-obra qualificada e um treinamento prévio dos técnicos que irão operá-lo, como condiçōes essenciais para o sucesso do projeto. A titulo de ilustração. o custo $\mathrm{cm}$ termos de hardware fica $\mathrm{cm}$ torno de R\$ 4.000 (quatro mil reais) e para aquisição do softhare em torno de RS 11.000 (onze mil reais), O que se pode fazer para reduzir custos é o compartilhamento de informações de interesse comum envolvendo diferentes instituiçoes. Por exemplo, tanto a prefeitura quanto as concessionárias podem precisar de informaçōes sobre as vias urbanas. As empresas de transporte público também podem ser beneficiadas com o planejamento de novas linhas. reduzindo custos e melhorando a eficiêneia do sistema.

O custo para a aquisição do soffware e compra dos equipamentos necessários para o perfeito desempenho das funçð̃es de digitalizaçấo de dados, processamento de dados e apresentaçâo das informaçōes é pequeno quando comparado com o custo para a montagem das bases de dados, que é a etapa mais demorada e cara.

Recomenda-se que institutos de pesquisas, prefeituras e empresas operadoras realizem convênios, a fim de que as informaçôes que serăo geradas pela implementação de SIGs nas principais cidades do país sejam aproveitadas e que possam se converter em açoes concretas para a melhoria da qualidade de vida em nossas cidades.

Espera-se ainda que a implantação de um sistema de informações para usuários de transporte coletivo possa contribuir para a melhoria da prestação dos serviços essenciais à sociedade. melhorando assim a imagem da administração pública perante a sociedade. 
Uma sugestão para um futuro trabalho de pesquisa seria a criaçào de meios para disponibilizaçåo de uma base de dados geográfica atualizada cuntendo informaçóes referentes ao sistema de transportes, via Internet. Desta forma, um maior número de pessoas teria acesso a informaçỏes públicas de maneira rápida, confiável e eficiente. Além disso, pode-se incrementar o comando de localização geográfica de endereços para o formato brasileiro utilizando-se o kit de programaçäo GISDK. Alguns pontos adicionais que podem ser acrescentados: entrada de dados para o formato brasileiro: localizaçảo de endereços rodoviários; codificação fonética para os nomes dos logradouros, facilitando a digitação do endereço; além ć claro, de interfaces personalizadas para cada usuário. 


\section{REFERẼNCIAS BIBLIOGRÁFICAS}

ALENCAR, V.C., AQUINO, M.S. (1994). Um Sistema de Informação Geográfica para Planejamento de Rotas de Ónibus. In: CONGRESSO DE GEOPROCESSAMENTO - GIS BRASIL 94, Curitiba, 1994. Anais. p. 1-9.

ANDRADE. R.C.R.; MENDES, A.P.D. (1995). Plano Multimodal de Transportes para o Estado de Minas Gerais: Uma Abordagem ao Sistema Informatizado de Planejamento de Iransportes. In: CONGRESSO NACIONAL DE TRANSPORTES PÜBLICOS - ANTP, 10, Såo Paulo, 1995, Anais. p. 361-368.

ANTP - ASSOCIAÇÃO NACIONAL DE TRANSPORTES PÚBLICOS (1997a).

Transporte Humano - Cidades com Qualidade de Vida. São Paulo, 1997. Cap.1. p.18-26: Desenvolvimento Uúbano e Politico de Transporte e Trânsito. Cap.5. p.99-132: Infra-estrutura. Cap.6. 133-212: Transporte Público

ANTP - ASSOCIAÇÃO NACIONAL DE TRANSPORTES PÚBLICOS (1997b). INFORMATTVO ANTP - $\mathrm{n}^{2} 47$, dezernbro/97,

BALASSIANO, B. (1997). Planejamento Estratégico de Transportes Considerando Sistemas de Média e Baixa Capacidade. In: CONGRESSO DE PESQUISA E ENSINO EM TRANSPORTES - ANPET. 11, Rio de Janeiro, 1997. Anais. v.1, p.203-216.

BARTOL.I, S.P.; FORTES, J.A.A.S.; ANDRADE, N.P. (1996). Sistema de Informação Geografica (SIG) como Instrumento para Avaliaçăo da Acessibilidade Locacional de Paradas de Ónibus. In: CONGRESSO DE PESQUUSA E ENSINO EM TRANSPORTES - ANPET, 10. Brasilia, 1996. Anais. v.1, p.245-256.

CAI.IJURI, M.L.; ROHM. S.A. (1994). Sistemas de Informacōes Geogräficas. Universidade Federal de Viçosa - Imprensa Universitária, Minas Gerais.

CALIPER (1995). Programmer's Guide, Version 3.0. Newton, Ma, Caliper Corporation. 
CALIPER (1996a), Travel Demand Modeling with TransCAD 3.0. Newton, Ma. Caliper Corporation.

CALIPER (1996b). TransCAD - Transportation GIS Software. User's Guide, Version 3.0) for Windows. Newton, Ma, Caliper Corporation.

CÂMARA. G.: CASANOVA, M.A.; HEMERLY. A.S; MAGALHĀES G.C.; MEDEIROS. C.M.B. (1996). Anatomia de Sistemas de Informaçâo Geográfica. Campinas, 10 Escola de Computaçào. 1996. Cap.1, p.5-20: Conceitos Básicos. Cap.2, p.21-36: Sistemas de Informação Geogrática.

CHAPleAU, R.: AllaRD, B.; TRÉPANIER, M. (1996). Transit Path Calculation Supported by Special Geographic Information System-Transil Information System. Transportation Research Record. 1521, p.98-107.

DANTAS, A.S.: TACO, P.W.G.; YAMASHTA, Y. (1996). Sistemas de Informação Geográfica em Transportes: O Estudo do Estado da Are. In: CONGRESSO DE PESQUISA E ENSINO EM TRANSPORTES - ANPET, 10, Brasilia. 1996. Anais, v1. p.211-222.

DAVIS JR, C.A. (1997). Aumentando a Eficiència da Soluçâo de Caminho Minimo em SIG. In: CONGRESSO DE GEOPROCESSAMENTO - GIS BRASIL 97, Curitiba. CD-ROM.

DAVIS JR. C.A.; FONSECA, F.T. (1994). Geoprocessamemto $\mathrm{cm}$ Belo Horizonte: Aplicaçðes. In: CONGRESSO DE GEOPROCESSAMENTO - GIS BRASIL 94. Curitiba, 1994. Anais. p.41-46.

FERRARl, R. (1996). Cenários Alternativos para o Uso de GIS em Municipios. AplicaçBes. In: CONGRFSSO DE GEOPROCESSAMENTO - GIS BRASIL 96, Curitiba, 1996. Anais. p.17-23.

FERRARI. R. (1997), Viagem ao STG. Curitiba, Sagres. 
FERRA7, A.C.P. (1997). Transporte Público Urbano Notas de Aula do Curso de pós graduaça em Transportes. Sâo Carlos. Escola de Engenharia de São Carlos, Universidade de São Paulo.

FERREIRA, F.E.; SÁ, L.A.C.M; LOCH, C.; MAYERLE, S.F. (1994). Mctodologia para o Planejamento da Rede Transportes coletivos urbanos por ónibus. In: CONGRESSO DE PESQUISA E ENSINO EM TRANSPORTFS - ANPET, 8. Recife, 1994, Anuis. v. 1, p.529-539.

KAGAN, H; ROSSFTO, C.F.; CUSTÓDIO, P.S.; MARTINS, W.C. (1992). Uso de Sistema de Intormaçóes Geográficas no Planejamento de Transportes. In: CONGRESSO DE PESQUISA E ENSINO EM TRANSPORTES - ANPEI, 6 , Rio de Janeiro, 1992. Anais. v.2, p.892-909.

LEIPNIK, M.R.; KEMP, K.K. LOAICIGA, H.A. (1993). Implementation of GIS for Water Resouces Planning and Management. Journal of Water Resources Planning and Management, v.119, n.2. p.184-205.

L.OUREIRO, C.F.G.; RALSTON, B.A. (1996). SIG como Plataforma para Modelos de Análise de Redes de Transporte. In: CONGRESSO DE PESQUISA E ENSINO EM TRANSPORTES - ANPET, 10, Brasilia, 1996. Anais. v.1, p.235-244.

MARQUES, H.N.; SILVA, A.N.R. (1997). Um Sistema de Informações para usuários de Transporte Coletivo em Cidades de Médio Porte. In: CONGRESSO DE PESQUTSA E ENSINO EM TRANSPORTES - ANPET, 11, Rio de Janeiro. 1997. Anais, v. 1, p.138-146.

MARTINS. W.C; IVERSSON. G. (1993). Criação de Uma Base de dados Georeferenciada para Estudos de Planejamento Regional de Transportes no Brasil. In: CONGRESSO DE PESQUUSA E ENSINO EM TRANSPORTES - ANPET, 7. Săo Paulo, 1993. Anais. v.2, p.617-625. 
MERCEDES BEN7 DO BRASIL (1987). Sistema de Transporte Coletivo por Ónibus Planejamento e Operagăo. Departamento de Sistemas de Trânsito e Transporte Mercedes Benz do Brasil. São Paulo, 1987. Cap.2, p.6-12: Sistema de Transporte Coletivo Urbano. Cap.3, p.13-51: Planejamento de um Sistema de Transporte Coletivo. Cap.5. p.57-77: Programaçâo da Operação do Transporte Coletivo por Ônibus.

NASSI, C.D,; GUEDES, E.P.; LINS, F.J.P.; BRAGA, A.F.; SILVA, F.S.P.; AGUIAR. 11.P. (1996). Adaptaçăo Gráfica de uma Base Cartográfica Voltada para os Problemas de Transportes. In: SEMANA ESTADUAL DE GEOPROCESSAMENTO - SEGEO, 1, Rio de Janeiro, 1996. Anais. p131-140.

NASSI, C.D.; SANTOS, M.P.S.; BODMER. M.: FILHO. R.D.O.: GAVA. R.M. (1994). Adaptaçăo Gráfica de uma Base Cartográfica de um Municipio Voltada para os Problemas de Transporte Público. In: CONGRESSO DE PESQUISA E ENSINO EM TRANSPORTES - ANPET, 8, Recife, 1994. Anais. v.1, p.541-550.

NOVAES, A.G.; ROSSETO, C.F. (1993). Localizaçâo de Depósitos numa Rede Logística com Auxilio de GIS. In: CONGRESSO DE PESQUISA E ENSINO EM TRANSPORTES - ANPET. 7. São Paulo. 1993. Anais. v.2, p.605-616.

OLIVEIRA, M.G.S. (1997). Produção e Análise de Planos Semafóricos de Tempo Fixo Usando Sistemas de Informaçôes Geográficas. Rio de Janeiro, 126p. Dissertaçâo (Mestrado) - Universidade Federal do Rio de Janeiro, COPPE.

OLIVEIRA. M.G.S.: RIBEIRO. P.C.M. (1997). Aplicação de Sistemas de Informaçòes Geográficas em Coordenação Semafórica. In: CONGRESSO DE PESQUISA E ENSINO EM TRANSPORTES - ANPET, 11, Rio de Janeiro, 1997. Anais. v.1. p. 113-125.

PADIL HA, E. (1998). Por uma Politica de Transportes Urbanos. Folha de São Paulo. São Paulo, 31 mar. Caderno 1, p.3. 
PINTO, A.B.; LINDAU, L.A. (1997). Cadastro de Linhas de Ônibus utilizando Sistemas de Informaçăo Geográfica e GPS, in: CONGRESSO DE PESQUISA E ENSINO EM TIRANSPORTES - ANPET, 11, Rio de Janeiro, 1997, Anais. v.1, p.126-137.

PIMENTEL, F.L.; SALGADO, A.C. (1994). Uma Visão sobre SIG. In: CONGRESSO DE PESQUISA E ENSINO EM TRANSPORTES - ANPET, 8, Recife, 1994. Anais. v.1, p.517-528.

RAMAI.HO, G.G.C., CALIJURI, M.L. (1994). Sistemas de Informaçòes Geográficas: Conceitos Fundamentais. REM - R. Esc. Minas, Ouro Preto, 47 (2): 134-142, abr. jun.

ROSSETO, C.F; CUNHA, C.B. (1994). A Aplicaçấo do Geoprocessamento na Roteirização de Veiculos. In: CONGRESSO DE GEOPROCESSAMENTO - GIS BRASIl 94, 1, Curitiba, 1994. Anais. p.35-44.

SH.VA, A.N.R. (1995). Os Sistemas de Informação Geográfica e a Fngenharia de Iransportes no Brasil. In: WORKSHOP SISTEMAS DE INFORMAÇOES GEOGRÁFiCAS - ANPET, 9, São Carlos, São Paulo, 1995. p.1-8.

SILVA, A.N.R.; FERRAZ, A.C.P. (1991). Transporte Público Urbano - Operaçâo e Administraçầo. Notas de Aula do Curso de graduaçāo. Sào Carlos. Escola de Engenharia de Såo Carlos. Universidade de São Paulo.

SILVA, A.N.R.; KAWAMOTO, E. (1995). Using GiS to Improve Urban Public Transportation - A Case Study in a Developing Country. In: WORLD CONFERENCE ON TRANSPORT RFSEARCH - WCRTS, 7, Book of abstracts. Sydney, Australia, 1995. p.5.4.

SIIVA, A.N.R.; LIMA, R.S.; MELO, J.1.O. (1997). Introduzindo os Sistemas de Informaçōes Geográficas no Ensino de Engenharia de Transportes. In: CONGRESSO DE PESQUTSA E ENSINO EM TRANSPORTES - ANPET, 11. Rio de Janeiro, 1997. Anais. v.2, p.685-691. 
SILVA, A.N.R.: IOTT, C.P.; MARGARIDO, S.A.; PAMPOLHA, V.M.P. (1996). Quem não tem Tiger... Revista Fator GIS, n.14, p18-19.

SILVA, A.N.R.; MFNDES FII.HO, J.T.; RAIA JR, A.A. (1995). Using GIS to Evaluate the Impacts of Urban Growth on the Transit System of a Brazilian Medium-Sized City. In: INTERNATIONAL. CONFERENCE ON COMPUTERS IN URBAN PLANNING AND URBAN MANAGEMENT. 4. Proceedings. Melbourne, Australia, 1995, p.255-266.

SILVA, A.N.R; VARGAS, E.N.7.; ITO, L.E.; CUBAS, S.I.B. (1994). O Uso de Sistemas de Informaçào Geográfica no Planejamento e Reestruturação de Sistemas de Transporte Público Urbano, In: CONGRESSO LATINOAMERICANO DE TRANSPORTE PÚBLICO Y IRBANO - CLATPU, 7, Memorias. Buenos Aires, Argentina, tomo 2, p.333-342.

SII.VA, A.N.R.; WAERDEN, P.V D. (1997). First steps with a Geographic Information System for transportation. Ribeirăo Preto, São Francisco.

SILVA, D.M.; LINDAU, L.A. (1997). Potencial dos Sistemas Avançados (AP'TS) no Transporte Coletivo Urbano por Ônibus. In: CONGRESSO DE PESQUISA E ENSINO EM TRANSPORTES - ANPET, 11, Rio de Janeiro, 1997. Anais. v.1, p. $510-518$.

SILVA, M.P.; ALMEIDA. C.L.T.: RUBIRA, J.A.C;; BRAGLIA, I.M. (1997). O Processo de Implantação de um Sistema de Informaçōes Geogrấficas no Planejamento do Transporte Integrado ao Metrô/SP. In: CONGRESSO DE GEOPROCESSAMENTO - GIS BRASIL 97, Curitiba, CD-ROM.

SIQUEIRA, C.A.B.; CASSUNDÉ, M.I.V. (1994). O Geoprocessamento como Insirumenta de Gestāo de Transporte Coletivo na EMTU/ RECIFE. In: CONGRESSO DE PESQUISA E ENSINO EM TRANSPORTES - ANPET, 8, Recife, 1994. Anais. v. 1, p.551-556. 
TACO, P.W.G.; YAMASHITA, Y.; SOUZA, N.M. (1996). Definiçăo de setores Agregados Homogêneos (SAH) para a Análise de Zonas de Tráfego (ZT) usando Sensoriamento Remoto. In: CONGRESSO DE PESQUISA E ENSTNO EM TRANSPORTES - ANPET, 10. Brasilia, 1996. Anais. v.1, p.223-234.

TEIXEIRA, A.M.A.; MORET71, E.; CHRISTOFOLETT1, A. (1992). introduçâo aos Sistemas de Informaçào Geográfica. Rio Claro, ediçào do autor.

VIVIANI, E.; SORIA, M.H.A.; SILVA, A.N.R. (1994). Gerenciamento de Vias não Pavimentadas e a Utilizaçào de Sistemas de Informação Geográfica. In: CONGRESSO BRASILEIRO DE CADASTRO TÉCNICO MULTIFINALITARIO, 1, Florianópolis, 1994. Anais. p.118-126.

VUCHIC. V.R. (1981). Trban Public Transportation - Systems and Technology. New Jersey, Prentice Hall.

WAERDEN, P.V D; TIMMERMANS, H. (1996). Transportation Planning and the use of Transcad. Transportes, v. $4, n .1$ e 2, p. $25-37$.

ZIIPPO, C.A.: DAVIS JR, (.A.; MEIREII.ES A.A.C. (1996). Geoprocessamento no Sistema de Transporte e Trânsito de Belo Horizonte. In: CONGRESSO DE GEOPROCESSAMENTO - GIS BRASIL 96. Curitiba, 1996. Anais, p. 376-387. 